
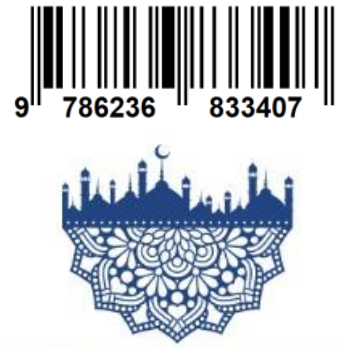

MEMBENARKAN ALLAH DALAM IMAN : MEMBACA AGIDAH DENGAN NALAR KRITIS DZULFIKAR AKBAR ROMADLON, M.Ud DONI SEPTI, LC., M.Pd

MEMBENARKAN ALLAH DALAM IMAN :

MEMBACA AQIDAH DENGAN NALAR KRITIS

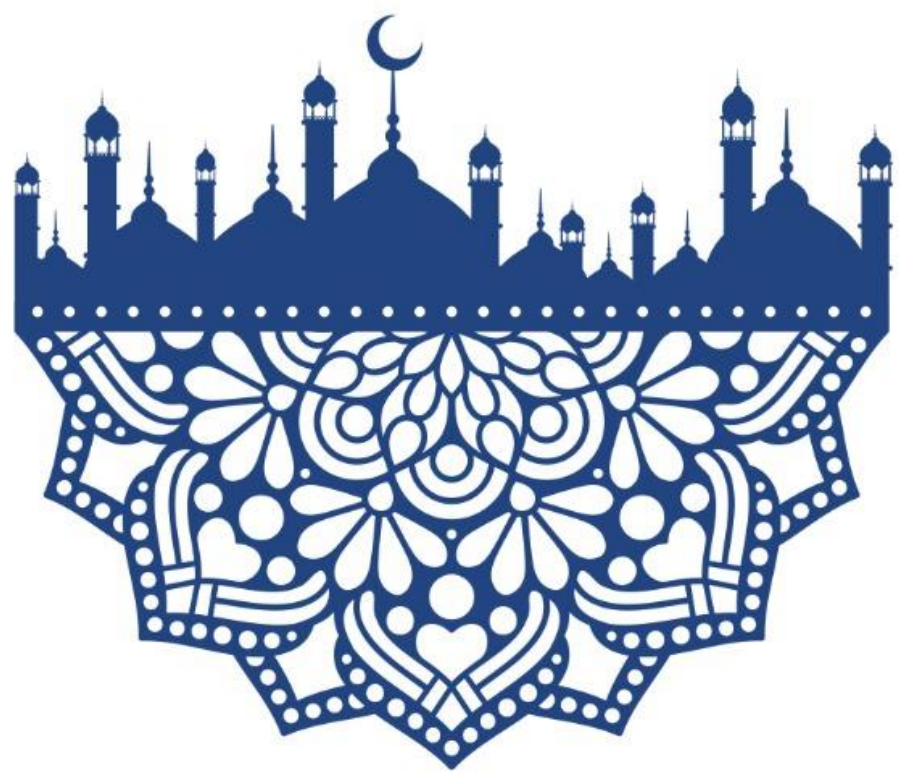

DZULFIKAR AKBAR ROMADLON, M.Ud DONI SEPTI, LC., M.Pd

BUKU AJAR

UNIVERSITAS MUHAMMADIYAH SIDOARJO 


\title{
BUKU AJAR \\ MEMBENARKAN ALLAH DALAM IMAN: \\ MEMBACA AQIDAH DENGAN NALAR KRITIS
}

\author{
Oleh \\ Dzulfikar Akbar Romadlon, M.Ud. \\ Doni Septi, M.Pd.
}

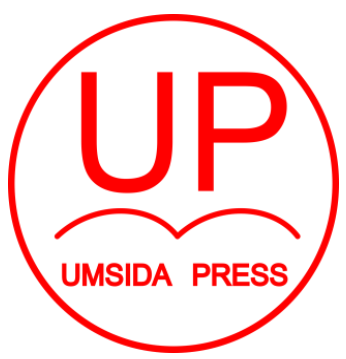

Diterbitkan oleh

UMSIDA PRESS

UNIVERSITAS MUHAMMADIYAH SIDOARJO

2020 


\section{BUKU AJAR:}

MEMBENARKAN ALLAH DALAM IMAN:

\section{MEMBACA AQIDAH DENGAN NALAR KRITIS}

\section{Penulis :}

Dzulfikar Akbar Romadlon, M.Ud.

Doni Septi, M.Pd.

\section{ISBN :}

978-623-6833-40-7

\section{Editor :}

Dr. Eni Fariyatul Fahyuni, S.Psi., M.Pd.I.

\section{Design Sampul dan Tata Letak :}

Mochamad Nasrulloh, S.Pd.

Amy Yoga Prajati, S.Kom.

\section{Penerbit :}

UMSIDA Press

Anggota IKAPI No. 218/Anggota Luar Biasa/JTI/2019

Anggota APPTI No.002 0181092017

\section{Alamat Redaksi :}

Universitas Muhammadiyah Sidoarjo

Jl. Mojopahit No 666B

Sidoarjo, Jawa TImur

Cetakan pertama, November 2020

(C) Hak cipta dilindungi undang-undang

Dilarang memperbanyak karya tulis ini dengan suatu apapun tanpa ijin tertulis dari penerbit. 


\section{KATA PENGANTAR}

Alhamdulillah semua ucapan syukur hanya pantas dihaturkan kepada Allah Swt. Shalawat serta salam selalu tercurahkan kepada Rasullullah Saw dan paea pengikutnya yang selalu menjadikan Aqidah sebagai landasan, Syari'ah sebagai jalan, dan Akhlak sebagai tujuan dalam kehidupan.

Aqidah Islam yang terpatri dalam kalbu bukan hanya sekedar pemahaman yang tersusun atau sekedar wacana yang dibenturbenturkan, namun ia adalah proses pembenaran terhadap konten dari aqidah itu sendiri. Ada 2 model manusia dalam melakukan pembenaran: Pertama, orang yang membenarkan dengan kalbunya tanpa perlu mempertanyakan atau menyelidikinya. Kedua, orang yang tidak mau mempercayai sesuatu hal begitu saja sebelum ia memperoleh bukti yang kuat terkait hal tersebut.

Buku ini berjudul "Membenarkan Allah dalam Imaan", ditulis khusus untuk orang model kedua, yang ingin memuaskan rasa ingin tahunya tentang apakah kebenaran yang diyakininya sudah pasti benar, ataukah ia hanya dugaan-dugaan manusia? Dalam penulisan buku ini penulis ingin menunjukkan bahwa antara Aqidah Islam khususnya keimanan kepada Allah adalah sesuatu yang pasti dan dibuktikan dalam argumentasi yang logis.

Terakhir, penulis juga harus menghaturkan rasa terimakasih terhadap semua pihak yang membantu dalam penulisan. Juga permohonan maaf jika terdapat kesalahan atau kekurangan dalam penulisan, semua kritikan dan saran sangat dibutuhkan. Semoga Allah Swt menerima amal baik kita dan meringankan segala timbangan keburukan kita. Amin. 


\section{DAFTAR ISI}

Kata Pengantar 3

CP-MK 4

Muqoddimah: Belajar Aqidah Menggunakan Strategi REAP. 5

Teks I: Atheisme-Materialisme : What Is The Nature Of All Things?

Teks II: Mengenal Agnostik 35

Teks III: Problematika Wujud Tuhan 43

Teks IV: Pembuktian Wujud Allah 52

Teks V: Nalar Sains Dalam Menyingkapi Eksistensi Allah 61

Teks VI: Monoteisme Dan Politeisme 74

Teks VII: Argumen Tentang Tauhid 94

Teks VIII: Hukum Kausalitas (Al-Ghazali) 101

Teks IX: Kekuasaan Dan Kehendak Allah Swt Dan Kaitannya Dengan Perbuatan Manusia 110

Teks X: Kalamullah 121

Daftar Pustaka. 134

Biografi 140 


\section{CAPAIAN PEMBELAJARAN MATA KULIAH (CP-MK)}

Setelah mengikuti matakuliah ini, diharapkan mahasiswa dapat memiliki kemampuan literasi informasi yaitu dapat menelusuri, menemukan, menganalisa, mengkritik, membandingkan, dan menggunakan berbagai hal yang terkait dengan "keimanan kepada Allah."

\begin{tabular}{|l|l|}
\hline Bab & Sub Capaian Pembelajaran Mata Kuliah \\
\hline $\begin{array}{l}\text { Prolog: Tantangan } \\
\text { Atheisme- } \\
\text { Materialisme }\end{array}$ & $\begin{array}{l}\text { Mahasiswa memahami tantangan ideologis } \\
\text { terhadap keimanan kepada Allah di masa } \\
\text { modern }\end{array}$ \\
\hline $\begin{array}{l}\text { Bab I: Apakah Allah } \\
\text { Ada? } \\
\text { Bab II: Keesaan } \\
\text { Allah }\end{array}$ & $\begin{array}{l}\text { Mahasiswa mampu membuktikan bahwa } \\
\text { naqli itu ada dan esa menggunakan dalil } \\
\text { Mahasiswa mampu membuktikan bahwa } \\
\text { Allah itu ada dan esa menggunakan dalil aqli }\end{array}$ \\
\hline $\begin{array}{l}\text { Bab III: Sifat dan } \\
\text { Nama-Nama Allah }\end{array}$ & $\begin{array}{l}\text { Mahasiswa mampu memahami dan } \\
\text { menjelaskan bahwa Allah itu memiliki nama } \\
\text { dan sifat yang sempurna }\end{array}$ \\
\hline $\begin{array}{l}\text { Bab IV: Penciptaan } \\
\text { Alam }\end{array}$ & $\begin{array}{l}\text { Mahasiswa mampu membuktikan bahwa } \\
\text { alam semesta itu diciptakan dan diatur oleh } \\
\text { Allah SWT. }\end{array}$ \\
\hline
\end{tabular}




\section{MUQODDIMAH}

\section{BELAJAR AQIDAH MENGGUNAKAN STRATEGI REAP}

Aqidah Akhlak adalah salah satu mata kuliah yang harus diampu oleh mahasiswa Pendidikan Agama Islam (PAI). Materi "Aqidah" dan "Akhlak" sebenarnya merupakan dua disiplin ilmu yang berbeda. Aqidah berkaitan dengan keyakinan yang ada dalam diri, sedangkan Akhlak lebih berkaitan dengan buah karakter, perbuatan, sikap, atau etika dari aqidah tersebut (Nurhayati, 2014). Namun melihat relasi antara keduanya maka materi ini digabungkan menjadi "Aqidah Akhlak" dan diajarkan mulai ditingkat sekolah hingga perguruan tinggi.

Mata kuliah Aqidah Akhlak harus diikuti oleh mahasiswa PAl, karena mereka adalah calon guru yang nantinya akan mengajarkan materi ini ditingkat MI, MTS, atau MA, atau yang sederajat. Maka untuk dapat menjadi guru Aqidah Akhlak, setiap calon guru perlu menguasai materi tersebut secara mendalam. Hal ini penting, karena mengajarkan materi ini membutuhkan kemampuan nalar yang logis dan kritis. Karena ketika calon guru nanti mengajarkan materi tersebut mereka akan menemukan pertanyaan-pertanyaan dari siswa yang kritis. Misalkan jika murid bertanya: “apakah bukti akan adanya Tuhan?" Tema ini berkaitan dengan masalah aqidah yang sangat mendasar. Jika guru tidak memiliki penguasaan materi yang cukup, dapat dimungkinkan kegagalan pembelajaran Aqidah Akhlak dan dapat menyebabkan pemahaman yang salah. Maka, semua calon guru PAI dituntut harus mampu menguasai berbagai permasalahan dalam materi tersebut secara logis dan ilmiah.

Pembelajaran Aqidah harus dilakukan dengan strategi yang tepat, karena jika tidak sesuai dapat menimbulkan kesesatan. Kelompok Mu'tazilah mewajibkan semua orang, termasuk orang 
awam, untuk mengetahui berbagai perdebatan dalam hal aqidah yang menjadi objek Ilmu Kalam (Jabbar, 1996). Menurut Imam AlGhazali hal ini tidak dapat dibenarkan, karena orang awam jika bertemu dengan ilmu kalam, mereka akan kebingungan. Namun, Imam Al-Ghazali tidak mengharamkan Ilmu Kalam, karena hal itu berguna untuk menjaga Aqidah Islam dari berbagai tantangan baik tantangan dari kelompok ahli bid'ah, atau tantangan eksternal yang datang dari luar Islam (Al-Ghazali, 2005).

Imam Al-Ghazali memberikan sebuah metode bagi anak kecil dan bagi orang awam, dalam mempelajari aqidah, cukup baginya diberikan penguatan dengan strategi penyampaian menggunakan ayat Al-Qur'an dan Hadith, dicampur dengan seni dalam menyampaikan. Sedangkan IImu Kalam, hanya boleh diajarkan kepada orang yang memiliki kualifikasi keilmuan. Bagi pelajar IImu Kalam harus didasari dengan aqidah dan metodologi keilmuan yang benar, sehingga mampu menjadi benteng pertahanan bagi aqidah Islam (Al-Ghazali, 2005).

Untuk tingkat Perguruan Tinggi pengembangan kemampuan thingking skill adalah suatu keniscayaan. Sehingga harus dimasukkan beberapa materi Ilmu Kalam dan Filsafat dalam pembelajaran Aqidah agar ia mampu untuk memberikan argumentasi terhadap Aqidah Islam yang diyakininya. Walaupun materi yang diajarkan harus selalu berada pada bimbingan guru, agar tidak tersesat sebagaimana yang dikhawatirkan Imam AlGhazali.

Dengan penanaman Aqidah diharapkan mampu memunculkan Akhlak yang baik. Karena setiap bentuk keyakinan yang ada dalam rukun iman memiliki implikasi etis dalam diri manusia. Sehingga Aqidah Islam yang diyakini oleh setiap individu harus menghasilkan akhlaq yang timbul dalam perbuatan. Oleh karenanya guru materi Aqidah Akhlak harus mampu memunculkan relasi ini dalam setiap pembelajarannya sehingga materi Aqidah 
Akhlak mampu memunculkan karakter yang baik dalam diri siswa (Ginanjar \& Kurniawati, 2017).

Agar calon guru mampu menjadi guru yang kompeten maka mereka memerlukan kemampuan "literasi informasi" terkait dengan tema-tema yang ada dalam Aqidah Akhlak. Literasi informasi yang dimaksud adalah keahlian dalam mengakses dan mengevaluasi informasi secara efektif untuk memecahkan masalah dan membuat keputusan. Dengan memiliki kemampuan ini seseorang dapat mudah untuk belajar, karena mereka mampu untuk mengelola informasi, mengevaluasi, memilah-milah, dan menggunakannya. Atau dapat disimpulkan bahwa kemampuan literasi informasi adalah kemampuan untuk berfikir melalui berbagai sumber literatur.

Calon guru membutuhkan kemampuan ini, karena hampir seluruh materi yang diajarkan dalam Aqidah Akhlak bersifat teoritis. Sehingga dalam materi buku teks yang digunakan, selalu berisi konsep-konsep yang harus dibaca dengan nalar yang kritis dan dicari perbandingannya melalui sumber-sumber informasi lain baik yang ada di perpustakaan, internet, maupun media massa. Oleh karenanya dibutuhkan sebuah strategi pembelajaran yang membantu calon guru dalam memahami teks bahan ajar yang menumbuhkan kemampuan berfikir kritis (Pattah, 2014).

Maka dalam pembelajaran Aqidah Akhlak diperlukan strategi dan metode pembelajaran yang sesuai untuk menumbuhkan kemampuan literasi informasi. Di antara strategi yang dapat diterapkan adalah strategi reading, encoding, annotating, dan pondering (REAP), yaitu strategi yang sering digunakan untuk menumbuhkan skill berfikir yang kritis. Strategi REAP dapat digunakan baik untuk siswa sekolah dasar hingga menengah. Dalam penelitian Andarini dan Ali terhadap tiga sekolah dasar di Jogjakarta dicapai hasil bahwa strategi REAP memberikan efek yang signifikan dan positif terhadap pemahaman bacaan siswa 
kelas 5 sekolah dasar (Cahyaningtyas \& Mustadi, 2018). Juga penelitian Sukma dan Haryadi tentang penerapan strategi REAP dan Request untuk anak SMP dicapai hasil bahwa strategi REAP lebih efektif dibandingkan strategi tradisional dan strategi Request (Sukma \& Haryadi, 2016). Juga pada penelitian Fera Zasrianita tentang penerapan REAP dalam pelajaran Reading (memahami teks bahasa Inggris) untuk anak MTS disimpulkan bahwa REAP membantu siswa dalam memahami teks-teks berbahasa Inggris (Zasrianita, 2016). Juga kesimpulan oleh Rutela Renette, bahwa strategi ini memiliki keuntungan di setiap langkahnya untuk membantu siswa dalam memahami teks (Renette, 2016). Namun dari penelitian-penelitian di atas hanya terfokus pada peningkatan siswa dalam memahami teks-teks Bahasa Inggris, belum pada pengembangan kemampuan berfikir.

\section{Literasi Informasi}

Literasi informasi merupakan serangkaian kemampuan yang dibutuhkan bagi seseorang untuk mengenali kapan sebuah informasi itu dibutuhkan, juga kemampuan untuk menempatkan, mengevaluasi, dan menggunakan secara efektif sebuah informasi. Oleh karenanya literasi informasi membutuhkan: 1. Penggunaan teknologi, 2. Penggunaan sumber informasi, 3. Mengelola sebuah proses, 4. Mengontrol penggunaan informasi, 5. Memperoleh pengetahuan 6. Mengembangkan pengetahuan, dan 7. Memperoleh kebijaksanaan. Pada tataran ini dengan memiliki kemampuan literasi informasi seseorang mampu dengan bijak mengelola pengetahuan yang berasal dari berbagai sumber, dan ini adalah definisi kebijaksanaan atau wisdom (Setyowati, 2015).

Kemampuan literasi informasi penting untuk dimiliki oleh mahasiswa karena hal itu akan mengembangkan nilai dari perguruan tinggi. Tujuan dari pengembangan literasi informasi di perguruan tinggi agar: Menciptakan mahasiswa yang mampu berfikir kritis, mengevaluasi informasi, menggunakan informasi 
yang relevan dengan lebih efisien dan efektif, serta terhindar dari plagiarisme (Ganggi, 2017). Maka untuk menciptakan kemampuan literasi informasi di tingkat perguruan tinggi perlu strategi dan Strategi pembelajaran yang memunculkan kemampuan berfikir kritis dan mampu mengolah data, diantaranya adalah Strategi REAP.

\section{Strategi Reading, Encoding, Annotating, Pondering (REAP)}

Untuk memunculkan critical thingking diperlukan Strategi yang cocok untuk digunakan dalam pembelajaran, diantaranya adalah Strategi REAP yang dirumuskan oleh Anthony Manzo. Strategi ini dibagi kedalam 4 tahapan: Pertama, Reading atau membaca teks untuk mengetahui pesan-pesan inti dari teks; Kedua, Encoding atau teks yang sudah dibaca ditulis ulang menggunakan bahasanya sendiri; Ketiga, Annotating atau memberi keterangan teks yang sudah ditulis dan mengaitkannya dengan sumber lainnya, atau dengan sudut pandang lainnya; Keempat, Pondering atau mendiskusikan teks yang sudah dianalisa kepada orang lain dan meminta respon mereka, kemudian membaca respon tersebut. Berdasarkan 4 tahapan ini, guru akan mengembangkan kemampuan berfikir siswa dari proses berfikir pasif menjadi proses berfikir aktif (Anthony V. Manzo, 1985).

Manzo dalam blognya menyebutkan bahwa tujuan dari REAP adalah untuk menciptakan pola pikir dari perspektif yang berbeda. Siswa seringkali tidak membaca teks dengan kritis. Dengan menggunakan REAP membuat mereka untuk kembali memeriksa informasi dan fakta-fakta yang ada dalam tulisan sebelum ia melangkah terlalu jauh yang mungkin akan menimbulkan kesalahpahaman. Kemudian siswa diharuskan menulis sebagai respons dari membaca, hal ini menanamkan kepekaan yang lebih besar pada mereka, khususnya ketika mereka mendiskusikan pemikiran mereka dengan orang lain. Dengan adanya respons terhadap teks hal ini sangat kondusif untuk 
menciptakan pembelajaran yang lebih aktif (U. Manzo \& Manzo, 2010).

Pemikiran kritis ditumbuhkan khususnya pada tahap annotating dan pondering. Di tahap annotating siswa mengomentari teks tersebut dengan menguji berbagai argumentasi yang ada dalam teks dan memikirkan apakah yang ditulis itu masuk akal atau tidak. Untuk mengatakan masuk akal mereka dituntut untuk membandingkan dari teks yang dibaca dengan teks-teks lain, sehingga memacunya untuk menganalisa ide pokok teks sehingga mahasiswa akan terbuka terhadap berbagai spektrum pemikiran.(A. Manzo et al., 2002) Di tahap pondering siswa mendiskusikan hasil pembahasannya dengan orang lain agar ia mampu meluaskan lebih jauh lagi cara pandangnya dan pemikirannya. Selain itu tahap ini juga berfungsi untuk memfalsifikasi pendapat yang sudah diyakininya setelah melakukan penelusuran melalui berbagai sumber, apakah argumentasi dari pendapat yang mereka yakini mampu dipertahankan ataukah tidak? Dengan demikian, mahasiswa mampu mempertimbangkan lebih jauh kekuatan dari argumentasi dan pendapatnya.

\section{Implementasi Strategi REAP dalam Pembelajaran Aqidah Akhlaq}

Untuk mengimplementasikan strategi ini pertama peneliti menawarkan sebuah modul teks yang berisi tentang berbagai masalah terkait "Iman kepada Allah". Metode REAP yang dilakukan kepada mahasiswa tidak cukup jika dilakukan selama 1 pertemuan saja. Oleh karenanya peneliti membagi kegiatan itu kedalam 3 kali pertemuan di setiap siklusnya. 1. Pelaksanakan reading dan encoding, 2. Pelaksanakan Annotating, 3. Pelaksanaan pondering.

Pada tahap reading mahasiswa membaca teks tersebut dan memahami pemikiran umum dari teks tersebut. Dalam teks itu mahasiswa membaca pemikiran, konsep, dan teori dari berbagai madhab dalam Islam terkait tema tersebut secara ringkas. Kegiatan 
ini dilakukan selama 30 menit karena ada beberapa konsep yang diperlukan pemahaman mendalam dalam memahaminya.

Tahap encoding dilakukan selama 30 menit berikutnya, yakni ketika mahasiswa menuliskan ulang pemahamannya dengan bahasanya sendiri berbeda dari teks asalnya. 30 menit berikutnya mereka menyampaikan pemahaman itu dalam sebuah forum diskusi perkelompok. Ketika mereka mampu menuliskan ulang dan menyampaikan argumentasi yang ada, maka pasti mereka sudah mampu memahami kandungan teks.

Pada pertemuan ke-dua, di tahap annotating lebih banyak bersifat penugasan agar mahasiswa menulis sebuah komentar yang disusun dalam artikel sederhana. Dan untuk memunculkan pemikiran yang analitis dan kritis terhadap teks mahasiswa perlu melakukan mahasiswa perlu belajar 4 model annotating sebagaimana yang dijelaskan oleh Manzo (Anthony V. Manzo, 1985) sebagai berikut: (ditambah dengan contoh yang diambil dari masalah-masalah Aqidah)

Thesis annotation, yaitu memberikan statement yang tajam sampai ke ide pokok dari suatu artikel atau buku. Statemen tersebut harus berdasarkan logika yang benar dan tersambungkan antara satu pernyataan kepernyataan lainnya. Misalkan: "Bagi Mu'tazilah kalam Allah itu diciptakan (makhluq). Namun jika kalam itu makhluq, sebelum ia diciptakan berarti Allah itu bisu (abkam)."

The probe annotation atau catatan penyelidikan dan pengujian, yaitu fokus pada melakukan pertanyaan-pertanyaan, penelusuran point dan argumentasi sehingga sebuah kesimpulan dan putusan dapat dicapai. Pertenyaan-pertanyaan itu berfungsi untuk memverifikasi konsekwensi dan alternatif dari teks. Misalkan: “Mengapa Mu'tazilah mengatakan bahwa kalam Allah itu makhluq? Apa konsekuensinya jika kalam Allah itu qidam (kekal)? 
Apakah ada cara untuk menyelesaikan dilema antara kalam Allah itu makhluq atau qidam?

Personal view annotation, catatan ini untuk menjawab bagaimana pengalaman seseorang dalam melihat dan perasaan melawan ide pokok dari suatu teks. Misalkan: "Mengapa banyak ulama' yang dipenjara, disiksa, bahkan dieksekusi pada masa Bani Abbasiyyah yang bermadhab Mu'tazilah, hanya karena tidak mau mengatakan bahwa kalam Allah. Padahal ini adalah salah satu masalah kecil dalam Aqidah Islam. Saya menyimpulkan bahwa ketika sebuah kekuasaan berdasarkan suatu ideologi tidak boleh memaksakan ideologinya kepada masyarakat yang berpandangan lain, karena hanya akan menciptakan kekerasan."

Inventive annotation atau catatan dengan sengaja difungsikan untuk membangun cara pandang dengan melihatnya dari konteks yang lain atau dengan mensintesiskan berbagai pendapat. Sebagai contoh: "Dua cara pandang antara kalam Allah sebagai qidam atau makhluq, memiliki argumentasi yang kuat dan sama-sama memiliki kelemahan jika ditinjau dari beberapa perspektif. Maka kita perlu keluar dari perdebatan ini dan melihat dari cara pandang lain. Bahwa keimanan kepada sifat Allah itu wajib dan tidak selayaknya kita memperdebatkan kedua hal itu, apalagi jika menciptakan suatu kekerasan atau mengkafirkan sesama muslim."

Selama seminggu mahasiswa harus mampu melakukan penulisan komentar berdasarkan 4 model komentar ini dan penelusuran melalui sumber-sumber lain baik untuk mendukung ataupun menolak dari tema yang diberikan.

Di pertemuan berikutnya dilakukan tahap pondering, yaitu kegiatan menimbang ulang ide dan konsep yang dimilikinya dengan cara mendiskusikan kepada kawan-kawannya. Selama 45 menit setiap mahasiswa memaparkan argumentasi dan pendapatnya, 
kemudian mahasiswa lainnnya memberikan pendapat, masukkan, ataupun kritikan. Semua kegiatan diskusi itu dinotuensikan oleh satu orang kemudian dalam 45 menit lainnya setiap kelompok memaparkan hasil diskusinya dalam kelas, kemudian setiap kelompok memberikan komentar terhadap hasil diskusi tersebut.

\section{Evaluasi}

1. Apa yang anda pahami dari Strategi REAP?

2. Jelaskan macam-macam annotating?

3. Mengapa kemampuan literasi informasi itu penting untuk dimiliki oleh mahasiswa?

\section{Referensi}

Al-Ghazali, A. H. (2005). Ihya' Ulumuddin (1st ed.). Dar Ibnu Hazm. Anthony V. Manzo. (1985). Expansion Modules for the ReQuest, CAT, GRP, and REAP Reading/Study Procedures. Journal of Reading, 28(6), 498-502. http://www.jstor.org/stable/40029529

Cahyaningtyas, A. P., \& Mustadi, A. (2018). The Effect of REAP Strategy on Reading Comprehension. SHS Web of Conferences 42, 00014, 1-6. https://doi.org/https://doi.org/10.1051/shsconf/2018420 0014

Ganggi, R. I. P. (2017). Pendidikan Pemakai di Perpustakaan Sebagai Upaya Pembentukan Pemustaka yang Literasi Informasi. Khizanah Al-Hikmah : Jurnal IImu Perpustakaan, Informasi, Dan Kearsipan, 5(1), 121-128. https://doi.org/http://dx.doi.org/10.24252/kah.v5i1a11

Ginanjar, M. H., \& Kurniawati, N. (2017). Pembelajaran Akidah Akhlak Dan Korelasinya Dengan Peningkatan Akhlak Al-Karimah Peserta Didik (Studi Kasus Di Madrasah Aliyah Shoutul Mimbar Al-Islami Tenjolaya Bogor). Jurnal Edukasi Islami Jurnal Pendidikan Islam, 6(12), 101-124. 
Jabbar, A. (1996). Sharh Ushuli I-Khamsah (3rd ed.). Maktabah Wahbah.

Manzo, A., Manzo, U., \& Albee, J. J. (2002). iREAP: Improving Reading, Writing, and Thinking in the Wired Classroom. Journal of Adolescent \& Adult Literacy, 46(1), 42-47. http://www.jstor.org/stable/40017504

Manzo, U., \& Manzo, A. V. (2010). The Informal Reading-Thinking Inventory (IR-TI) The Informal Reading-Thinking Inventory: Assessment Formats for Discovering Typical \& Otherwise Unrecognized Reading \& Writing Needs - and Strengths. http://anthony-manzo.blogspot.com/2010/06/informalreading-thinking-inventory-ir.html

Nurhayati. (2014). Akhlak dan Hubungannya dengan Aqidah dalam Islam. Mudarrisuna, 4(2), 289-309.

Pattah, S. H. (2014). Literasi Informasi Peningkatan Kompetensi Informasi dalam Proses Pembelajaran. Jurnal IImu Perpustakaan \& Kearsipan Khizanah Al-Hikmah, 2(2), 117128.

Renette, R. (2016). Using REAP (Read, Encode, Annotate, Ponder) In Teaching Reading. Proceedings of the Fourth International Seminar on English Language and Teaching (ISELT-4), 278282.

Setyowati, L. (2015). Literasi Informasi Dilihat dari Perspektif Modal Manusia. Libraria: Jurnal Perpustakaan, 3(2), 232-246. https://doi.org/10.21043/libraria.v312.1594

Spielvogel, J. J. (n.d.). Western Civilization (7th ed.). Thomson Wadsworth.

Sukma, \& Haryadi. (2016). Keefektifan Strategi REAP Dan Request Dalam Pembelajaran Membaca Pemahaman Siswa Kelas VIII Smp. LingTera, 3(1), 99-111. https://doi.org/http://dx.doi.org/10.21831/lt.v3i1.8476 
Zasrianita, F. (2016). Using Of Reading, Encoding, Annotating, And Pondering (REAP) Technique To Improve Students' Reading Comprehension (A Classroom Action Research at Eighth Grade Students in MTSN 1 Kota Bengkulu in Academic years 2016). Ta'dib, 19(2), 147-164. 


\section{TEKS I}

\section{Atheisme-Materialisme : What Is The Nature Of All Things?}

Atheisme merupakan suatu kata yang berasal dari yunani yaitu "Atheos", yang artinya suatu aliran yang ditujukan kepada seseorang yang mempunyai keyakinan yang bertolak belakang dengan agama, bahkan telah diyakini dan dijalankan di lingkungan masyarakat. Sedangkan atheisme menurut istilah adalah suatu paham atau aliran yang tidak mempercayai adaya Tuhan. Atheisme juga bisa diartikan sebagai suatu kepercayaan. Athesime sendiri memilih untuk tidak percaya kepada segala sesuatu karena dianggap tidak masuk akal. Paaham atheisme hanya percaya kepada segala sesuatu yang dianggap masuk akal, selain itu diaggap tidak ada. Oleh karena itu menurut mereka yang meyakini paham atheisme menganggap bahwa keberadaan Tuhan di alam semesta ini tidaklah ada. Karena wujud atau bentuk dari Tuhan tidak masuk akal dan tidak bisa difikirkan dengan akal pikiran. Mereka hanya mempercayai apa saja yang dianggap masuk akal, bisa difikir secara logis atau berfikir secara logika.

Pada hakikatnya, atheisme merupakan paham yang tidak percaya bahkan mengingkari tentang keberadaan Tuhan. Yang meliputi transendental, wujud yang mutlak, dan Maha Tinggi. Menurut orang atheis yang ada dan yang nampak hanyalah alam semesta, kemudian kehidupan itu hanya ada kehidupan duniawi saja sedangkan kehidupan rohani atau akhirat dianggap tidak ada dan hanya khayalan semata.

\section{Latar Belakang Munculnya Atheisme}

Pada abad ke-18, Baron D'Holbach orang yang pertama kali telah menyebut dirinya sebagai atheis. Ia juga menulis buku yang berjudul "Systeme De La Nature" yang berisikan tentang pengertian 
materialism filsafat, atheisme, dan determinisme yang sempit. Kemudian pada tahun 1772, Baron D'Holbach, ia berpendapat bahwa "semua anak dilahirkan sebagai atheis, karena mereka tidak tahu akan Tuhan", pada tahu itu pula buku dari Baron D'Holbach dan buku dari Common Sense dikutuk oleh parlemen paris, kemudian salinan dari buku tersebut dibakar habis di depan khalayak umum.

Pada akhir abad ke-18 di Eropa, atheisme dikenal dengan kepercayaan tersendiri, artiya mereka tidak percaya kepada Tuhan Yang Esa. Kemudian pada abad ke-20, terjadilah globalisasi yang memperluas istilah yang menyebut "ketidakpercayaan pada semua dewa/Tuhan", walaupun demikian atheisme memiliki definisi "ketidakpercayaan pada Tuhan Yang Esa". Kemudian terjadi perdebatan dalam kelompok filosofis untuk mendefinisikan ulang tentang atheisme sebagai "ketidakpercayaan pada dewa dewi", daripada ateisme sebagai kepercayaan tersendiri.

\section{Dasar Pemikiran Atheisme}

Dasar pemikiran dari atheisme sendiri ada dua, yaitu atheisme praktis dan atheisme teoritis.

\section{a. Atheisme praktis}

Menurut atheisme praktis individu itu hidup tanpa tuhan dan menjelaskan fenomena alam tanpa didasari dengan alasan pranormal. Menurut pandangan dari atheisme praktis, keberadaan Tuhan tidaklah dapat disangkal, namun dapat dianggap sebagai tidak berguna dan tidak penting, bagi mereka tujuan hidup kita bukanlah tuhan yang memberikan, Tuhan juga tidak berpengaruh dalam kehidupan yang kita jalankan sehari-hari. Atheisme praktis dapat dikatakan sebagai :

- Tidak tahu tentang konsep Tuhan dan dewa 
- Mengesampingkan tentang Tuhan dan religi

- Mengabaikan permasalahan tentang Tuhan dan agama

\section{b. Atheisme teoritis}

Bentuk dari atheisme teoritis berbeda-beda dan berasal dari argumentasi para filosofis dan dasar pemikiran yang berbeda-beda pula.

- Argumentasi dari epistimologis dan ontologis: Atheisme epistimologis berpendapat bahwa orang itu tidak dapat mengetahui Tuhan atau tidak mampu untuk mengetahui tentang keberadaan Tuhan itu sendiri. Sedangkan agnostisisme merupakan dasar pemikiran dari atheisme epistimologis.

- Argumentasi metafisika: Atheis metafisika secara jelas tidak percaya tentang keberadaan mahluk-makluk halus. Oleh karena itu sudah nampak sangat jelas bahwa atheis metafisika menolak tentang konsep-konsep yang berhubungan dengan ketuhanan.

- Argumentasi psikolois, sosiologis, dan ekonomi: Menurut Sigmund Freud dan Ludwig Feuerbach berpendapat bahwa kepercayaan keagamaan dan kepercayaan tentang Tuhan adalah ciptaan manusia semata, yang bermaksud untuk memenuhi dari segi keinginan dan kebutuhan psikologis maupun emosi manusia itu sendiri. Buddhis, Karl Marx, dan Friedrich Engles berpendapat bahwa kepercayaan akan Tuhan dan agama merupakan fungsi sosial yang hanya digunakan penguasa untuk menekan para pekerja.

- Argumentasi logis dan berdasarkan bukti: Atheisme logis memilki argument tentang konsep ketuhanan, seperti halnya Tuhan personal dalam Kristen, bagi mereka dianggap tidak konsisten. Orang atheis sangat menentang tentang keberadaan Tuhan dan mereka menganggap bahwa tidak cocok antara sifat-sifat yang 
dimiliki oleh Tuhan. Misalnya, sifat tentang Maha Tahu, Maha Adil, dll.

\section{Alasan Meyakini Paham Atheisme}

Menurut Arqom Kuswanjoyo ada beberapa alasan orang meyakini dan mengikuti paham atheisme, antara lain sebagai berikut

1. Kepercayaan tentang adanya Tuhan merupakan sebuah hasil pemikiran, kebiasaan dan harapan dari masyarakat.

2. Jika Tuhan itu ada, maka manusia tidak dapat merasakan kebebasan. Tetapi kenyataannya manusia itu sangat bebas berbuat. Maknanya Tuhan tidak ada.

3. Berpendapat bahwa dunia ini keseluruhan hanyalah bersifat nyata. Adanya alam semesta tidak membutuhkan bantuan dari luar dan semua yang terjadi di alam semesta ini hanyalah siklus yang berjalan , sehingga tidak membutuhkan bantuan dari orang lain.

4. Jika Tuhan bersifat Maha Kasih, maka Tuhan akan menghapus semua kejahatan yang dilakukan manusia. Namun kenyataannya tetap saja banyak kejahatan, oleh karena itu Tuhan tidak dapat bersifat Maha Kuasa dan Maha Kasih.

\section{Atheisme dan Materialisme}

Atheisme sangat berkaitan dengan Materialisme; yaitu sebuah aliran dalam bidang filsafat yang berpandangan hidup dan mencari dasar yang menjadikan segala sesuatu adalah sebagai tujuan utama terutama pada segi perbendaan seperti harta ataupun uang. Aliran materialisme ini mengesampingkan terhadap nilai-nilai, perbedaan-perbedaan yang bersifat non material seperti halnya setan, roh dan malaikat. Mereka mempercayai bahwa semua hal yang terjadi di dunia ini adalah sebuah hasil dari interasksi material. 
eorang yang berfilsafat dapat diumpamakan seorang yang berpijak di Bumi sedang tengadah ke bintang-bintang. Dia ingin mengetahui hakikat dirinya dalam kesemestaan galaxy. Atau seorang, yang berdiri dipuncak tinggi, memandang ke ngarai dan lembah dibawahnya. Dia ingin menyimak kehadirannya dengan kesemestaan yang ditatapnya. Materialisme memiliki pandangan bahwa benda itu adalah berkedudukan di bagian primer dan ide berkedudukan di bagian sekunder Maksudnya yaitu benda mempunyai kedudukan yang terpenting dan baru sesudahnya yaitu sebuah ide yang diletakkan dibagian sekunder. Materialisme merupakan proses menghilangkan hal-hal berbau mistis dan teori dari kenyataan yang mengaplikasikan kualifiasi fisik terhadap segala aspek kenyataan. Materialisme mengutamakan semua yang dapat dijamah akal danfenomena selalu dapat dijelaskan dengan ilmu pengetahuan. Materialisme dipahami sebagai sebuah faham yang menekankan pada hal yang bersifat materi daripada faktor immaterial. Oleh karena itu materialism dipandang sebagai faham yangmenentang segala yang immaterial sebagai sebuah kebenaran. Seiring denganperkembangan filsafat, materialisme justru memperluas deskripsi dari kebendaan itusendiri sehingga ide atau fikiran ataupun buah dari fikiran merupakan produk yangdihasilkan oleh mater

Aliran materialisme mempunyai pandangan seperti ini berdasarkan hal kenyatan yang mereka yakini yaitu mereka percaya akan proses waktu dan zat. Misalnya seperti menurut proses waktu lama sebelum manusia yang mendapatkan ide-ide itu ada di dalam dunia, alam ini sudah ada. Kemudi menurut proses zat manusia sendiri tidak dapat berfikir atau bahkan mendapatkan ide bila di tubuh mereka tidak terdapat sebuah organ yang bernama otak, karena menurut mereka otak adalah sebuh beda yang ada karena kebetulan yang dapat dirasakan oleh sebuah panca indera. Di dalam 
perkembangannya materialisme selalu menekankan bahwa tidak adanya hantu roh,setan ataupun pelaku-pelaku i materi Setiap perubahan peristiwa, aktifitas mempunyai sebab material, oleh karena itu penjelasan material merupakan penjelasan yang paling tepat untuk menjelaskan segala fenomena yang ada. Dikarenakan realitas satu-satunya adalah materi, tentu segala sesuatu dalam alam semesta dapat dijelaskan dalam kerangka material (fisik), tidak ada Allah ataupun dunia suprantural, karena segala sesuatu merupakan manifestasi dari materi. Aliran materialisme adalah suatu aliran filsafat yang berisikan tentang ajaran kebendaan dimana suatu benda merupakan sumber dari segalanya. Sebuah aliran materialisme yang banyak diperhatikan dan dijadikan sebagai landasan pemikiran adalah positivisme, menurut positivisme kalau sesuatu itu ada maka adanya itu adalah jumlahnya. Jadi dapat disimpulkan bahwa mereka ini hidup hanya berorientasi pada materi.

\section{Agama dalam tinjauan Materialisme}

Materialisme pada awal munculnya adalah suatu ajaran filsafat yang menekankan keunggulan materi daripada non-materi. Ajaran ini menekankan bahwa materi merupakan hal yang primer dan non-materi (ide/ruhanial) dipandang sebagai hal yang sekuder. Ajaran filsafat ini masih mengakui adanya wujud lain diluar materi atau bahkan menjadikan wujud diluar materi itu sebagai hal yang material. Aliran ini diperkenalkan pertama kali oleh filsuf alam di zaman Yunani kuno sehingga akan tampak bahwa materialism muncul sebagai bentuk usaha untuk melepaskan diri dari mitologi Yunani untuk mencari jawaban rasional dari kenyataan yang tetap maupun yang berubah-ubah di dalam semesta alam.

Pemikiran materialisme merupakan awal berubahnya kebudayaan manusia ketika manusia mulai membentuk peraturan kehidupan dengan cara baru. Dimana pada kehidupan sebelumnya 
berdasarkan pada sistem kepercayaan yang kemudian tergantikan oleh sistem pemikiran atau akal yang melibatkan alam sebagai materi dalam menyusun suatu kehidupan. Jika dicermati lebih dalam, seiring dengan adanya pemikiran Materialisme pada periode modern, definisi Materialisme telah mengalami pergeseran yang dilakukan oleh kaum Materialisme itu sendiri. Materialisme pada periode ini tidak hanya menekankan keunggulan yang materi daripada yang nonmateri, tetapi juga mulai mengasumsikan bahwa segala sesuatu yang nonmateri (termasuk Agama) merupa kan hasil dari pergerakan materi itu sendiri.

Penyerangan dari kaum Materialisme terhadap Agama semakin kuat ketika faham Materialisme mekanis diploklamirkan. Pengikut Materialisme menyadari bahwa materi memiliki keluasan yang membutuhkan ruang dan memliki bentuk rupa. Kesadaran tersebut cukup memaksa kaum Materialisme untuk mengakui bahwa materi takluk kepada hukum yang mengaturnya, tidak ada ada kebebasan didalam semesta ini, semua telah tunduk dan takluk kepada hukum yang mengaturnya. Namun, bukan untuk mengakui adanya Tuhan sang Maha Pengatur, tetapi mereka menggantikan kedudukan Tuhan yang maha mengatur segalanya dengan dengan hukum alam sebagai "sang Pengatur segalanya".

Tidak cukup sampai disitu saja, penyerangan terhadap Agama dari kaum materialistik berlanjut lebih frontal seiring dengan lahirnya teori Materialisme dialektik yang dibawa oleh Karl Marx, seorang filosof, sosiolog, ekonom, politisi dan aktivis. Ia menyebut pemikirannya sebagai kritik politik ekonomi dari perspektif kaum kelas sosial rendah yang dikenal sebagai filsafat kritis. Materialisme yang dimaksud Marx adalah hal-hal yang nyata, realita, apa yang ada di dalam realita sosial. Marx mengesampingkan hal-hal yang bersifat abstrak, tidak bisa dilihat, lebih-lebih sesuatu yang sifatnya hanya 
keyakinan. Konsep Materialisme Marx merupakan kritik atas gagasan idealisme yang dominan dalam pemikiran filsafat saat itu, terutama yang dikembangkan oleh Hegel. Aliran idealisme melihat kesadaran dan gagasan sebagai pangkal yang mempengaruhi dan menyebabkan tindakan individu dan sekaligus membentuk realita sosial.

Pemikiran Karl Marx menjadi patokan para ilmuan karena sangat berguna sebagai rujukan analisis. Para pengikut faham materialisme yang dikemukakan oleh Karl Marx dikenal dengan Marxisme. Tujuan utama ajaran marxisme yaitu mendudukkan masyarakat khususnya kaum buruh pada martabat dan kekuasaannya. Sedangkan untuk mencapai tujuan tersebut, perlu diadakan perubahan dalam sistem sosial secara besar-besaran (revolusi). Melalui revolusi maka segala bentuk penindasan, ketidakadilan, alienasi yang sumbernya dari alat produksi secara pribadi dapat dihapuskan.

Pemikiran Karl Marx dipengaruhi oleh pemikiran Hegel yang terkenal dengan filsafat politiknya. la menempatkan rasionalitas dan kebebasan sebagai nilai tertinggi. Saat melihat kondisi Pussia yang sedang tidak stabil, Karl Marx muda menemukan filsafal Hegel yang menentukan arah pamikirannya. Karl marx muda dan para doktor membuat kelompok intelektual muda yang kritis dan radikal. Filsafat Hegel-lah yang mereka gunakan sebagai alat kritik terhadap kekolotan Negara Prussia. Sehingga mereka mendapat julukan Hegelian-muda. Filsafat Hegel sangat cocok untuk mengkritik sistem politik yang otoriter karena lebih menekankan pada rasionalitas dan kebebasan.

Esensi dari pemikiran filsafat Marx adalah materialisme historis dan sosialisme. Materialisme historis berpendapat bahwa perilaku manusia ditentukan oleh kedudukan materi, bukan pada 
ide. Karena ide adalah bagian dari materi. Marx memetakan materialisme ke dalam materialisme historis dan materialisme dialektis. Materialisme historis merupakan pandangan ekonomi terhadap sejarah. Kata historis ditempatkan Marx dengan maksud untuk menjelaskan berbagai tingkat perkembangan ekonomi masyarakat yang terjadi sepanjang zaman. Sedangkan materialisme yang dimaksud Marx adalah mengacu pada pengertian benda sebagai kenyataan yang pokok. Marx tetap konsekuen memakai kata historical materialisme untuk menunjukkan sikapnya yang bertentangan dengan filsafat idealisme. Filsafat materialisme beranggapan bahwa kenyataan berada di luar persepsi manusia, demikian juga diakui adanya kenyataan objektif sebagai penentu terakhir dari ide. Sedangkan filsafat idealism menegaskan bahwa segenap kesadaran didasarkan pada ide-ide dan mengingkari adanya realitas di belakang ide-ide manusia.

Pemikiran Marx masih digunakan oleh para pemikir modern maupun postmodern. Bahkan sebagian manusia bisa dikatakan marxian dan sebagian lainnya pengkritik Marx. Para pengkritik Marx terbagi menjadi dua, yakni pengkritik Marx yang sangat sinis karena menurut mereka pemikiran Marx bersifat sederhana dalam mengambil langkah dengan mengamati kenyataan empiris bahwa status sosial yang tidak pernah berubah dan prediksi marx tentang kapitalisme yang akan mengalami keruntuhan pun tidak pernah terjaadi. Sedangkan pengkritik pembela Marx berpendapat bahwa perubahan kelas sosial yang tidak pernah menunjukkan hasilnya adalah hasil yang tidak jelas. Karena masyarakat yang hidup pada saat ini sangat berbeda dengan masyarakat Marx abad 19. Persoalan yang dihadapi Marx adalah kemiskinan kaum buruh, sementara persoalan bagi masyarakat industri Barat sekarang adalah kesejahteraan. Meskipun kemenangan belum terwujud secara 
sempurna, namun bagi para pengikutnya, kemenangan itu akan terwujud pada waktunya.

Meskipun begitu, terdapat pemikiran yang berbeda diantara Hegel dan Marx. Hegel merumuskan teori. Tetapi dari teori tersebut harus menjadi kenyataan sehingga tidak hanya bersifat teoritis tetapi juga praktis. Pemikiran harus menjadi unsur pendorong perubahan sosial. Namun selain Hegel, pemikiran Karl Marx juga dipengaruhi oleh filsafat Feuerbach. Seperti Feurbach, Marx tidak puas dengan pemikiran abstrak (abstract thought). Mereka menginginkan yang lebih empiris. Jika Feurbach hanya mengganti esensi agama dan esensi manusia, Marx menambahkan bahwa esensi manusia adalah totalitas hubungan sosial. Seperti Hegel, Marx berpandangan bahwa sejarah berjalan sesuai dengan prinsip dialektika: tesis-antitesis-sintetis. Akan tetapi, jika Hegel berpendapat bahwa semua tesis itu bersifat ide, Marx menggantinya dengan yang bersifat materi karena, ide terlahir akibat kondisi sosial.

Menurut Marx, filsafat Feuerbach mampu mengungkapkan pandangan Hegel tentang ungkapan manusia yang merasa terasingkan dari dirinya sendiri. Sedangkan menurut Feuerbach, keterasingan terungkap dalam agama. Sedangkan menurut Feuerbach, keterasingan terungkap dalam agama. Marx menerima tafsiran tersebut, tetapi ia menunjukkan bahwa agama merupakan keterasingan sekunder. Sedangkan keterasingan primer adalah manusia yang mulai asing dengan hakikatnya sebagai makhluk sosial dimana munculnya rasa individualis dalam diri sebagaimana yang telah tersungkap dalam indivualisme Modern.

Karl Marx seakan memberi sebuah Logika baru bagi kaum Materialisme untuk mengingkari kekuasaan sang maha kuasa. Alam semesta selaku materi tidak hanya tunduk kepada hukum alam, 
tetapi tunduk kepada hukum yang dinamai dengan Dialektika. Dialektika merupakan buah tangan filsuf idealis yang sengaja dihadirkan untuk mengukuhkan adanya wujud non-materi. Namun dalam Materialisme dialektis, absolute idea dalam dialektis Hegel digantikan dengan materi, tidak ada lagi pelantunan dari ide, melainkan pelantunan dari materi ke materi. Dikarenakan yang ada ini hanyalah materi yang bergerak dan menghasilkan sebuah materi baru, maka ajaran ini dengan tegas menolak adanya sang Maha Pencipta.

Lebih jauh, Materialisme Dialektika Marx ini bermuara pada asumsi ketidaktergantungan material terhadap immaterial yang dapat membentuk simpulan bahwa tidak ada sang Maha. Aspekaspek kehidupan yang bersifat ruhanial dianggap bukan hal yang penting bahkan akan dianggap tidak benar ketika tidak dapat dibuktikan secara empiris. Oleh karena itu, Materialisme seringkali dianggap sebagai faham yang anti terhadap keberadaan Tuhan.

Materialisme Dialektika menyatakan segala sesuatu yang ruhanial itu ada sebagai hasil ciptaan dari segala sesuatu yang material. Manusia melihat dan merasakan fenomena-fenomena pada alam semesta, membentuk pemikiran baru dan kemudian menciptakan sosok yang immaterial digambarkan dengan kekuasaan dan ke"maha"annya. Sehingga Agama adalah ciptaan materi berupa manusia dan alam yang bergerak saling berhubungan dan bergantung satu sama lain. Penerapan dari Materialisme dialektis ini merupakan faktor timbulnya Materialisme historis. Dalam artian lain, Materialisme dialektis membenarkan bahwa hakikat sejarah terjadi karena proses-proses ekonomi dan yang berkenaan dengan rohaniserta perkembangan manusia hanyalah akibat dan refleksi dari kegiatan ekonomi manusia. Salah satu dari banyak hal yang menjadi pembeda antara Materialisme modern dengan Materialisme yang 
lebih tua adalah terletak pada kemajuan ilmu, segala macam bentuk ataupun hasil penyelidikan fisika ataupun kimia (yang tentunya berdasarkan materi), pada hakikatnya hanyalah sebuah upaya untuk mencari pembatas mengenai apa yang dikatakan tentang materi.

Ketika Marx membicarakan tentang agama, terkadang dalam suasana ungkapan yang baik, dan terkadang dalam suasana ungkapan yang sangat kejam dan kasar. Menurutnya agama adalah sebuah ilusi dan rasa ketakutan yaitu sebuah ilusi konsekuensi yang sangat menyakitkan. Menurutnya agama menjadi bentuk ideologi yang paling nyata dan sangat ekstrim. Agama adalah sebuah kepercayaan yang mempunyai tujuan untuk mengatur kehidupan manusia dimana yang mengatur adalah sang penguasa. Meskipun doktrin antara satu agama dengan agama yang lain itu berbeda, namun pada dasarnya spesifik manusia bergantung pada satu hal yaitu kondisi kehidupan sosial yang pasti bergantung pada suatu kekuatan materi yang tentunya dapat mengatur manusia dimanapun dan kapan pun. Marx memperjelas lagi, bahwa mempercayai Tuhan itu adalah sebuah lambing kekecewaan atas kekalahan dalam memperjuangkan kelas. Menurut Marx, dalam agama Tuhan selalu disembah dan ditaati, padahal semua kepunyaan manusia. Dalam filsafat, Hegel memberikan pujian-pujian kepada yang absolut, padahal semua itu harus ditujukan kepada manusia yang telah bekerja keras membanting demi memenuhi kebutuhan hidupnya. Menurut Marx, Hegel juga melakukan kesalahan yang sama, karena memandang pemerintahan di Negara modern sebagai ekspresi dari ide absolut yang paling nyata.

Marx memiliki pandangan bahwa agama merupakan instrument untuk menindas dan memanipulasi kelas subordinat dalam masyarakat. Marx menghubungkan pandangannya yang tidak terlepas dari teori historis materialistisnya yang menganggap bahwa 
manusia sebagai modal produksi. la memberikan gambaran kehidupan produksi dengan ketaatan atau aturan terhadap agama. Menurutnya, semakin seseorang itu mempercayai dan mengabdi pada agamanya, maka ia akan semakin kehilangan jati dirinya sendiri. la akan sepenuhnya dipengaruhi dan dikuasai oleh agamanya. Begitu pula denga produksi, semakin banyak orang itu memproduksi, maka semakin lupa tentang jati dirinya, apalagi terhadap masyarakat diseitarnya, sedangkan menurut Marx sendiri semakin banyak seseorang memproduksi, maka seseorang itu semakin tidak bebas, la dikuasai dan dibatasi oleh penciptanya sendiri.

Marx memiliki pendapat yang sangat bertentangan dengan ajaran agama di dunia. Pada umumnya agama mengajarkan bahwa yang menciptkan manusia adalah Tuhan, Fakta ini pun berbalik menurut Marx bukan Tuhan yang menciptakan manusia, tapi manusia yang menciptakan Tuhan serta manusia itu sendiri juga yang menciptakan agama. Menurutnya agama menjadi candu bagi manusia dan menjadi simbol manusia yang tertindas. la menggambarkan agama seperti obat yang tidak bisa menyembuhkan penyakit, hanya saja mengurangi rasa sakit. Agama memberikan harapan ilusi pada manusia mengenai kehidupan spiritual yang lebih baik di masa yang akan datang.

Di sini materialisme berarti sama saja dengan atheism karena merupakan suatu paham yang meyakini hal yang terlihat (materi), dan tidak meyakini hal yang tak terlihat (non materi). Materialisme tidak percaya pada hal-hal ghaib misal roh,hantu,setan, malaikat, bahkan Tuhan. Jika diperhatikan pada zaman modern seperti sekarang ini (termasuk sikap materialis). Dan tampaknya hal tersebut tak lepas dari pandangan humanistic yang merupakan cikal bakal peradaban Barat modern. 
Bagi Marxisme, agama sangat tidak humanis. Hal ini dapat dilihat dari pemberontakan yang terjadi terhadap kekuasaan Gereja pada abad Pertengahan yang bersifat dogmatis. Pada saat itu, gereja mengeluarkan kebijakan yaitu harus tunduk apa yang diperintahkan dan apa yang boleh dan tidak boleh dipikirkan. Hal inilah yang dinamakan antroposentrisme atau bisa disebut humanism versi peradaban Barat. Antroposentrisme beranggapan bahwa hidup di dunia ini tidak berpusat pada Tuhan tetapi pada manusia atau hal yang terlihat. Revolusi ini merupakan revolusi paling berdarah di dunia, setelah revolusi ini semuanya tiba-tiba berubah, masyarakat Barat menjadi masyarakat yang bebas berfikir, Intinya adalah semangat yang lebih untuk menghargai nilai-nilai yang dibangun oleh manusia sendiri. Menurut antroposentrisme Tuhan tidak ada apaapanya karena manusia sebagai pusat dunia dan mereka sudah merasa cukup.

Selama ratusan tahun lebih manusia modern membatasi pandangannya hanya pada manusia. Manusia modern lebih mementingkan kesenangan kehidupan duniawi saja daripada mementingkan kesenangan yang lebih jauh dan mendalam seperti akhirat. Hal ini disebabkan karena mereka telah kehilangan kemampuan untuk membayangkan hal yang tidak masuk akal, tak terlihat (nonmateri).

Materialisme tentang alam, mereka memiliki pandangan bahwa ketika membicarakan tentang alam semesta pada dasarnya adalah ilmu pengetahuan sains, alam semesta terbentuk karena adanya kaitan yang berhubungan dengan materi. Mereka tidak mempercayai bahwa Tuhan terlibat dengan penciptaan alam semesta ini, yang harus mereka percayai adalah dengan mencari tahu atau mempelajari dari berbagai ilmu pengetahuan tentang alam semesta. Mereka lebih mengedepankan akal daripada wahyu, hal ini 
bisa disebut juga atheist. Berbicara tentang Jiwa-Tubuh. Menurut mereka semua itu tidaklah masuk akal karena hal tersebut tidak terlihat, intinya dalam tubuh ini tidak ada roh/jiwa. Mereka juga tidak mempercayai bahwa ada konsep kehidupan setelah mati, tidak mempercayai akhirat,surga dan neraka, mereka hanya memikirkan menjalani kehidupan ini dengan baik yaitu dengan mempelajari ilmu pengetahuan. Tidak mempercayai Tuhan, tidak mempercayai agama, mereka hanya mempercayai apa yang bisa terlihat oleh mata. Mengenai kebahagiaan mereka hanya memikirkan kebahagiaan dunia semata, meskipun mereka tidak pernah melakukan ibadah, apabila dalam kehidupan semakin kaya maka itu berarti indikasi bahwa Tuhan mencintainya. Semakin banyak hal yang duniawi yang didapat maka hal tersebut sudah termasuk prinsip kebahagiaan bagi mereka.

\section{Feurbach dan Materialisme}

Ajaran pokok dari Feurbach yaitu materialisme yang bergantung pada kebenaran materi. Menurut Feuerbach alam adalah dasar bagi manusia. Dengan demikian Feuerbach merubah konsep idea roh dari Hegel menjadi alam material. Menurutnya Yang disebut "Tuhan", adalah Hanya mimpi dari manusia. Kata "Tuhan" diganti dengan kata "hakekat manusia". Kemudian, Agama ganti dengan politik. Karena manusia sudah terlalu lama diasingkan dari dirinya sendiri, sekarang, manusia harus dikembalikan kepada dirinya sendiri.

Feuerbach mengatakan dalam tulisan Hakekat Agama Masehi bahwa tugas filsafat itu: "mengubah sahabat- sahabat Tuhan menjadi sahabat- sahabat manusia, mengubah kaum beriman menjadi pemikir- pemikir, mengubah orang yang beribadat menjadi 
orang yang bekerja, mengubah calon- calon untuk surga menjadi murid- murid untuk dunia ini, mengubah orang Kristiani yang menamai dirinya sendiri separuh malaikat, separuh binatang,' menjadi manusia seratus persen."

\section{TUHAN ADALAH PROYEKSI AKAL BUDI MANUSIA BELAKA}

Menurut Feuerbach, manusia tidak diciptakan oleh Tuhan, tetapi Tuhan diciptakan oleh manusia. Dalam proses ini ada tiga tahap: Manusia mengalami bahwa dia dapat bertanya terusmenerus, bahwa ia mempunyai kesadaran yang seakan - akan tak terhingga. Kesadaran dapat memuat apa saja. Tidak pernah ditemukan batas- batasnya."

Ketidak terhinggaan yang awalnya hanya suatu sifat dari kesadaran, akhirnya dijadikan sesuatu. Manusia menemukan ketidak terhinggaan di dalam dirinya sendiri, yang kemudian itu dianggap sebagai sesuatu yang berdiri sendiri, di luar manusia. Ketidak terhinggaan mulai ditulis dengan huruf- huruf besar oleh manusia. Ketidak terhinggaan Itulah yang dijadikan Tuhan.

Tuhan hanyalah ciptaan dari manusia, dihormati dalam kebaktian. Itu berarti bahwa manusia menjadi hamba dari ciptaannya. Manusia memandang dirinya sendiri sebagai ciptaan dari ciptaannya. Atau, ia telah memproyeksikan kebebasannya di luar dirinya sendiri, yaitu atas ciptaannya Sendiri.

\section{AGAMA BAGI FEUERBACH}

Agama menurut Feuerbach merupakan suatu gambaran dari keinginan manusia yang tak terbatas, yang dibentuk oleh manusia tentang dirinya sendiri dan tidak lebih dari proyeksi hakikat manusia. Agama itu hanya merupakan perwujudan cita- cita: "Ilusi religius yang terdiri dari suatu objek bersifat imanen pada pikiran kita yang 
kemudian

menjadi

lahiriah,

mewujudkannya,

mempersonifikasikannya.

Manusia hanya mengkhayal Tuhan dengan Kebijaksanaan, karsa, keadilan, cinta kasih, sekian banyak atribut kekal yang seluruhnya merupakan hakikat manusia yang sesungguhnya, dan yang (oleh manusia) diproyeksikan secara spontan di luar dirinya, ia mengobjektifkan hakikat itu dalam suatu subjek fantastis.

\section{Evaluasi}

1. Baca teks ini dengan seksama, kemudian lakukan paraphrase (encoding) di setiap sub babnya!

2. Buat sebuah komentar menggunakan Thesis annotation, The probe annotation, Personal view annotation, dan Inventive annotation terhadap teks di atas untuk mengomentari setiap sub-babnya!

3. Buat kelompok diskusi setiap kelompok terdiri dari 5 orang mendiskusikan masalah-masalah berikut dan tuliskan hasil diskusinya:

a. Kemunculan atheism

b. Hubungan antara atheism dan meterialisme

c. Argumentasi atheism

d. Agama perspektif materialism

e. Agama menurut Karl Marx

f. Agama menurut Feurbach

\section{Referensi}

Jackson J. Spielvogel, Western Civilization, 7th ed. (Canada: Thomson Wadsworth, n.d.);

Bertrand Russel, History of Western Philosophy and Its Connection With Political and Social Circumstances From the Earliest Times to The Present Days, 2nd ed. (New York: George Allen and Unwin LTD, 1949). 
lew, Antony. God and Philosophy. Amherst, NY: Prometheus Books, 2005. 


\section{TEKS II}

\section{MENGENAL AGNOSTIK}

Agnostisisme adalah suatu faham bahwa ada atau tidaknya Tuhan atau sesuatu yang tidak bisa dilihat dengan kasat mata itu tidak bisa dibuktikan atau tidak bisa diketahui. Atau definisi lain yaitu, suatu faham bahwa kemampuan akal fikiran manusia tidak mampu menjangkau sesuatu yang tidak nyata tersebut, bahkan manusia tidak mampu untuk memberikan alasan yang logis untuk menjelaskan atau membenarkan keyakinan akan ada atau tidaknya Tuhan/sesuatu yang tidak dilihat tersebut.

Antonim dari faham Agnostik adalah faham Gnostik. Faham gnostic berbalik dari faham agnostic. Sangat jelas bahwa faham agnostik mengutarakan bahwa Tuhan tidak dapat diketatahui atau tidak dapat dibuktikan ada atau tidaknya, melaikan faham gnostik mengutarakan bahwa Tuhan dapat diketahui atau dapat dibuktikan ada atau tidanya.

Dengan begitu, seorang yang menganut pandangan agnostic ini tidak percaya akan adanya tuhan karena mereka berpendapat sesuatu yang tidak terlihat dengan kasat mata atau tidak bisa dibuktikan kebenarannya ini tidak dapat diyakini dengan begitu saja, kecuali jika ada sesuatu yang dapat membuktikan ada atau tidaknya Tuhan tersebut mereka mau meyakininya. Atau mereka akan menyerahkan semua kebenaraan sampai ada yang bisa membuktikannya. Kelompok agnostic merasa bahwa kebenaran yang mustahil untuk diketahui karena kepastian itu sulit untuk digapai.

Ada beberapa pandangan terhadap agnostic, diantaranya yaitu agnostic lebih mengedepankan ilmu pengetahuin/sains. Dengan demikian pengetahuan tentang sesuatu yang tidak nyata itu tidak bisa diketahui dengan pasti oleh manusia atas keberadaannya 
sangat perlu untuk dibuktikan. Lalu soal kepercayaannya, kelompok agnostic ada yang percaya dan mengikuti suatu agama namun tidak sepenuhnya mereka juga tetap tidak percaya akan Tuhan.

Agnostic sering dikaitkan dengan Atheis, karena mempunyai definisi yang hampir sama. Atheis diartikan sebagai suatu pandangan yang tidak sama sekali mempercayai dengan keberadaan Dewa/Tuhan. Namun ada perbedaan diantara agnostic dan atheis tersebut. Perbedaan yang paling mendasar yaitu, bagi kelompok yang menganut agnostic berpegangan bahwa kepastian atas persoalan adanya tuhan itu sangat susah untuk dibuktikan kebenarannya bahkan tidak mampu untuk dibuktikan, karena itu mereka memilih jalan tenganya, tidak menolak namun tidak mudah untuk percaya sebelum ada kejelasan atas pembuktiannya.

Sedangkan atheis, mereka sudah kekeh berpendapat bahwa sangat tidak munkin jika Dewa/Tuhan itu ada di dunia, mereka tidak perlu bukti apa-apa, karena memang mereka hidup tanpa adanya Tuhan.

Meskipun ada perbedaan diantara keduanya, agnostic dengan atheis mempunyai persamaan atas keberadaan Tuhan, pada akhirnya mereka percaya bahwa yang bertanggung jawab atas segala hal adalah dirinya sendiri, bukan dari sesuatu yang tidak bisa diliat oleh kasat mata.

Kita sebagai makhluk social, tentutanya harus menerepkan sebuah toleransi, kita tidak boleh menyalahkan atau menggunjing agama lain atau kepercayaan lain. Termasuk kepada kelompok yang menganut faham agnostic, ada beberapa cara untuk menyikapi kelompok agnostic ini,

pertama kita harus meluruskan pandangan mereka, karena jika kita hanya menyalahkan tanpa ada argument yang mendukung 
atau tidak dengan argument yang logis, itu akan hanya membuat kelompok agnostic semakin kuat dengan anostisismenya

Kedua Bersikap dengan membuat mereka merasa nyaman, dan memahami cara berpikir mereka, dan tidak menghakimi mereka, sehingga dengan begitu kemungkinan mereka akan mudah menerima kita dan mendengarkan apa yang akan kita beri/pencerahan.

Ketiga menerangkan kepada mereka dengan baik dan sabar bahwa segala sesuatu tidak harus ada bukti mutlak. Dan dalam segala hal seseorang tidak perlu untuk mempercayai sesuatu meskipun pembuktiannya tidak $100 \%$. Seperti contohnya, apabila kita membeli makanan di suatu restoran, kita tidak perlu untuk mencari tau terlebih dahulu membuktikan apakah makanan tersebut dibuat dengan sisi kesehatan atau kebersihan.

Keempat memberi pandangan bahwa Tuhan ada karena alam semesta ini sudah terlanjur terwujud sehingga jika ada sesuatu yang sudah terwujud pasti ada sebab yang membuat terwujudnya sesuatu itu ada. Dan dapat dilihat wujud alam semesta ini sangatlah besar maka penciptanya juga otomatis berwujud lebih besar dari apa yang diciptakannya yang bisa disebut dengan wajibil wujud. Seperti contoh kecilnya apakah seorang ibu bisa melahirkan dirinya sendiri? Tentu saja tidak, karna menciptakan diri sendiri itu mustahil.

Melihat penjelasan-penjelasan diatas, banyak diluar sana yang mempercayai adanya Tuhan namun tidak kafah atau keseluruhan, dengan kata lain mereka tidak perlu bukti atau membuktikannya, tapi mereka takut akan dosa dan segala yang dilarang oleh agama mereka, dan mengerjakan segala hal yang diperintahkan kepada mereka dengan dasar takut kepada Tuhantuhan mereka. Karena mereka melakukan sesuatu yang sudah 
tertanam dari kecil seperti dosa dan akan masuk neraka, neraka digambarkan sesuatu yang menyeramkan, dan perbuatan baik akan masuk syurga dengan gambaran sesuatu yan sangat indah dan bagus, tanpa mereka mencari atu butuh bukti nyatanya.

\section{Istilah Berkembangnya Agnostik}

Perkembangan Agnostik berarti dari bahasa yunani kuno yang artinya tanpa dan gnosis, berarti " pengetahuan" untuk menggambarka pengetahuan spiritual atau mistis.

Menurut penelitian Filsuf Wiliam L. Rowe adalah seseorang yang tidak percaya atau mendustakan keberadaan dewa-dewa sedangkan teis ateis masing-masing adalah orang percaya dan tidak percaya akan adanya Allah, agnostisismeadalah pandangan bahwa akal manusia tidak mampu untuk membenarkan suatu keyakinan dan tujuan bahwa Tuahn ada atau tidak.

Sedangkan kualifikasi agnostisisme beberapa pendapat filosofis yaitu tentang alam semesta di kualifikasi tingkat keraguan. Beberapa filosof mengatakan bahwa seorang tidak seharusnya mengatakan bahwa dirinya tahu atau percaya pada sesuatu sebelum mengetahui dasar-dasar ilmiah untuk mengetahui percaya atupun tidak.

Sedangkan menurut filosof-filosof lain adalah mereka para agnostik seseorang yang yang tidak mempercayai keberadaan dewa dewi atupun Tuhan sedangkan teis ataupun ateis mereka antara percaya ataupun tidak tentang keberadaan Tuhan.

akan tetapi dalam agnostisisme mereka berpendapat bahwa secara rasional membenarkan keyakinan tentang apa yang telah diciptakan dan dilakukan Tuhan dan apakah Tuhan itu ada ataupun tidak ada. 


\section{Agnostik Perspektif Islam}

Lalu, bagaimanakah islam menanggapi hal ini? Mereka selalu menyangkal dan selalu tidak setuju terhadap adanya Tuhan atau adanya semua agama. Agnostik berfikiran bahwa mungkin, mereka dapat menerima sumber hukum agama akan tetapi meraka tetap berpegang teguh pada prinsip mereka yakni tidak beragama. Tujuan hidup mereka adalah tidak lain untuk dirinya sendiri. Atau mereka hidup semaunya dan seenaknya (monoton) tidak mengenal baik buruknya kecuali menuruti syahwat/ kemanusiannya sendiri. Karena seorang agnostik berfikiran hidup ini adalah sesuatu yang relatif dimana menurutnya baik atau buruk. Dan tidak ada yang absolut dalam hidup. Seorang agnostik tidak mempunyai atau memiliki standar nilai moralitas kecuali keinginannya sendiri atau kemauannya sendiri. Dalam bermasyarakat. Kepercayaan setiap orang atau setiap individual untuk meyakini suatu aliran adalah hal dan progresif masing-masing. Ada beberapa jenis-jenis agnostisisme diantaranya adalah:

\section{Agnostik ateisme}

Seorang agnostik atheisme berpendapat meraka tidak percaya akan keberadaan Tuhan/ataupun Dewa manapun. Akan tetapi meraka ( seorang agnostik atheisme) percaya akan keberadaan Tuhan.

\section{Agnostik teisme}

Adapaun seorang Agnostik teisme berpendapat bahwa mereka tidak pernah akan percaya hal itu,tidak percaya dan tidak mengakui keberadaan Tuhan. Akan tetapi mereka menuntut akan keberadaan atas pengakuan atau keberadaan Tuhan ada ataupun tidak. Maksudnya adalah mereak menginginkan bukti yang nyata tentang keberadaan Tuhan itu ada atau tidak. 


\section{Apatis atau agnostisisme pragmatis}

Seorang Apatis atau agnostisisme pragmatis meraka berpandangan bahwa tidak ada pembuktian yang nyata dalam agama tidak ada bukti ada atau tidak adanya Tuhan ataupun Dewa.

\section{Agnostisisme Kuat}

Adapun menurut Agnostisisme kuat adalah menyatakan ada ataupun tidak adanya Tuhan ataupun Dewa dan tidak ada bukti yang kuat untuk mengetahui dengan alasan tidak mampu untuk membuktikan adanya Tuhan, dalam ilmu pengetahuan, seseorang untuk menentukan atau memutuskan dengan pengalaman subyeknya sendiri.

\section{Agnostisisme lemah}

Seorang agnostik yang lemah ataupun bisa di sebut dengan lunak, empiris, atau keduniawian berpandangan bahwa keberadaan Dewa/Tuhan untuk saat ini mereka tidak mengetahuinya akan tetapi pada suatu saat nanti sekarang ataupun nusa pasti akan menemukan keberdaan atau akan diketahui. Sehingga seseorangpun akan menunda penilaian sampai akan benar-benar terbukti nyata sebagai alasan yang dapat dipercaya. Maksudnya adalah sekarang mungkin meraka tidak mengetahui keberadaan Tuhan tetapi suatu saat nanti ada mereka akan menemukan sesuatu yang dipercaya bahwa Tuhan benar-benar ada.

\section{Kesimpulan}

Agnosistisme adalah berpendapat bahwa sesungguhnya keberadaan sang pencipta Tuhan atau dewa tidak mungkin dapat diketahui atau dibuktikan. Pada dasarnya agnostik yang di sebut tanpa pengetahuan. Sedangkan agnostik dan atheis itu berbeda pendapat dimana agnostisisme berpendapat bahwa keberadaan Tuhan ataupun dewa tidak mungkin dapat dibuktikan. Sedangkan 
argumentasi menurut atheisme adalah mengklaim bahwa Tuhan atau dewa tidak ada dan tidak akan pernah ada. Dan tidak akan pernah bisa dibuktikan.

Sedangkan menurut pandangan islam menekankan bahwa sesungguhnya kita sebagai umat manusia harus menerima dengan iman bahwa sesungguhnya Allah itu ada yang menciptakan seluruh alam semesta ini. Hakikatnya Allah itu ada tetapi tidak dapat dilihat dari indra manusia. Tidak dapat di sentuh kecuali Allah memperlihatkan diri-Nya. Sebagai umat islam yang yakin dan percaya akan keberadaan Allah maka tidak ada alasan untuk meragukan keberadaannya. Kita umat islam harus percaya akan keberadaanNya dan ketentuanNya.

\section{Evaluasi}

1. Baca teks ini dengan seksama, kemudian lakukan paraphrase (encoding) di setiap sub babnya!

2. Buat sebuah komentar menggunakan Thesis annotation, The probe annotation, Personal view annotation, dan Inventive annotation terhadap teks di atas untuk mengomentari setiap sub-babnya!

3. Buat kelompok diskusi setiap kelompok terdiri dari 5 orang mendiskusikan masalah-masalah berikut dan tuliskan hasil diskusinya:

a. Pengertian Agnosistisme

b. Kemunculan Agnosistisme

c. Jenis Agnosistisme

d. Pandangan Islam tentang Agnosistisme

\section{Referensi}

Hume, David. Dialogues Concerning Natural Religion. New York: Routledge, 1991.

Huxley, Thomas. Collected Essays Volumes 1-7. New York: D. Appleton \& Co, 1896-1910. 
Huxley, Thomas. Man's Place in Nature and other Anthropological Essays, London: Macmillan, 1906.

Kannengeiser, C. "Atheism." Encyclopedia of Religion. Edited by Mercia Eliade. New York: MacMillan Publishing, 1987.

Ray, Matthew Alun. Subjectivity and Irreligion: Atheism and Agnosticism in Kant, Schopenhauer, and Nietzsche. Burlington, VT: Ashgate, 2003.

Spencer, Herbert. First Principles. London: Routledge/Thoemmes, 1996.

Stein, Gordon. "Agnosticism." In The Encyclopedia of Unbelief (Volume 1). Buffalo, NY: Prometheus Books, 1985. 3-4. 


\section{TEKS III}

\section{PROBLEMATIKA WUJUD TUHAN}

Problematika wujud tuhan, ketika berbicara tentang problrmatika wujud tuhan yang ada di dunia ini tidak lepas dari keyakinan dan bermacam-macam pendapat. Dalam koneks wujud tuhan atau bagaiman tuhan itu berbentuk, ataupun seperti apa tuhan itu terbentuk pasti banyak sekali yang masih memperdebatkannya. Apalagi para pemikir-pemikir yang radiks, bahkan yang semulanya sudah mempunyai wawasan tentang ketuhanan, itu masih banyak yang dipertanyaan tentang wujud tuhan itu sendiri, apalagi yang sama sekali tidak mempunyai pegangan atau wawasan tentang ketuhanan yang pastinya banyak teka-teki yang masih terbesit di dalam pikiran ataupun jiwa. Keyakinan tentang tuhan pada diri setiap individu pastinya tidak bisa dipaksakan, karena konsep tuhan dalam dalam kehidupan sehari-hari sangatlah berpengaruh terhadap tindakan ataupun peristiwa-peristiwa yang terjadi pada setiap individu.

Di dalam bahasan tentang ketuhanan terdapat banyak sekali lingkaran-lingkaran yang dijadikan keyakinan pada setiap Negara. Ada kalanya yang mengharuskan memilki keyakinan tentang ketuhanan ataupun ada juga yang memilki konsep kebebasan pada setiap individu. Tetapi itu semua tetap saja tidak bisa mengetahui apa yang sebenarnya tersimpan didalam fikiran setiap orang meskipun itu sekecil debu. Karen itu semua memang terdapat sesuatu yang namanya hak yang tercipta di dalam setiap orang sehingga tidak ada satupun orang yang bisa mematenkan pemikiran seeorang kecuali dari diri mereka sendiri. Ada problematika wujud tuhan banyak sekali pertanyaan ataupun pandangan tentang ketuhanan itu sendiri, ada 
kalanya pertanyaan seperti, kenapa tuhan itu ada, kenapa tuhan itu tidak ada, kenapa tuhan itu tidap bisa dilihat, kenaa tuhan itu bisa dilihat, dan kenapa orang itu meyakini tuhan, bahkan ada juga kenapa orang itu tida meyakini tentang apa itu tuhan, dan ada juga kenapa ada suatu roh, dan kenapa juga tidak ada suatu jiwa ataupun kenapa ada roh dan jiwadan kenapa kok bisa tertampakkan pada diri mereka. Dari banyaknya pertannya tentang problematikaproblematika wujud tuhan pastinya tetap kembali ke awal. Kita tidak bisa memaksakan jawaban kita itu bisa disamakan pada setiap individu karena seperti yang telah disebutkan bahwa setiap orang tidak bisa mematennkan pmeikirian selain pemikiriran mereka sendiri.

Pada konsep pemikiran tentang ketuhanan. Tidak lepas dengan yang namanya agama. Didalam dunia pastinya banyak sekali berbagai agama yang dianut oleh setiap kelompok. Dan terdapat pula kelompok yang tidak meyakini tentang agama dan jiwa. Melihat itu semua tidak menutup kemungkinan karena memang setiap individu memilii pemikiran dan cara pandang yang berbeda-beda. Seiring berjalannya waktu banyak sekali pemikiran-pemikiran baru yang membawa keyakinan baru pada kehidupan sehigga banyak juga ajaran-ajaran baru yang terkandung didalamnya. Itu semua terjadi karena memang lama kelamaan pemikiran manusia terus berkembang baik secara negative ataupun positif. Ketika membahas agama atau keyakinan maka pasti muncul salah satu macam agama, seperti agama islam. Pada agama islam ini terbilang cukup banyak penganut yang menyakininya. Ada lagi kelompok yang meyakini agama Budha, Kristen dan banyak lainnya, serta terdapat pula kelompok yang menentang semua keyakinan itu.

Tak dapat dipungkiri Islam dalam sejarah panjang nya telah bersinggung dengan banyak agama dan aliran. Pada dasarnya Islam 
sangat menghargai kebebasan berkeyakinan dan berpendapat yang tentunya masih dalam garis wajar keislaman. Di dalam agama Islam memiliki keyakinan tentang ketuhanan yaitu wujud tuhan hanya satu Berbeda dengan agama-agama lain yang memiliki banyak tuhan. Tentunya di dunia ini semua orang memiliki pemikiran yang sama. Didalam suatu pandangan pastinya seseorang mempunyai persepsi ataupun argument yang berbeda beda dan tentunya semua yang di dapatkan didunia ini ada yang pro dan kontra.

Nah, Pada kali ini problem yang akan di sampaikan yaitu tentang tuhan, atau yang lebih tepatnya yaitu tentang wujud tuhan. Didalam konteks ini islam yang dari dasarnya sudah memilki pegangan dan arahan yang haqiqi yang pastinya sudah menjdi darah daging pada setiap pengikutnya, kemudian tak lupa pastinya juga bersanding kelompok ateis yang sangat tak lepas dari pembahasan tentang ketuhanan dan keyakinan.

\section{Problem Eksistensi Immateri}

Untuk yang pertama tentang wujud tuhan pastinya sudah sebagian kelompok yang berfikir bahwa tidak yakin akan adanya suatu ketuhanan dalam kehudupann mereka dan menganggap bahwa tuhan hanya sebagian dari kedupan mereka, kemudian ada yang memang benar -benar yakin tentang adanya tuhan, dan ada juga yang memilki keyakinan bahwa yang namanya tuhan itu memang benar-benar tidak ada dan tidak akan pernah ada, mereka tidak memikiran adanya tuhan, apalagi tentang wujud tuhan. Kelompok ini berfikiran bahwa yang namanya tuhan adalah Cuma rekayasa hati yang dijadikan sangkut paut pada kehidupan Kemudian dari sinilah kelompok tersebut banyak yang menyebutnya dengan ateis. Pada problem ini kelompok ateis ini memandang bahwa tuhan itu nihil dan tidak masuk akal, mereka menganggap bahwa semua 
agama itu memiliki sesuatu yang dipercayai itu sama, dan menilainya hal tersebut itu tidak benar.

Dalam artian anggapan tentang adannya tuhan dan jiwa adalah Cuma angan-angan manusia. Mereka merasa bahwa semua yang berada pada dirinya itu adalah sesuatu yang ada dengan sendirinya, tanpa memikirkan adanya sebab apa yang terdiri dalam kehidupannya. Seperti halnya mereka menganggap bahwa semua yang ada dunia ini memang ada dengan sendirinya dan tidak akan pernah berhenti. Konteks ini mereka rasa bahwa melihat kehidupan yang berjalan dari dulu hingga sekarang itu ada dengan sendirinya tanpa ada tuhan, hukuman, dan ganjaran, mereka berfikir bahwa semua yang terjadi di alam semesta ini murni karena Sesuatu itu sendiri yang memunculkannya

Kelompok atheis berfikir dan betanya-tanya kenapa kebanyakan orang itu mau mengikuti angan tuhan yang tidak jelas adannya serta mengikuti angan tersebut sebagai aturan jiwa pada diri seseorang yag kemudian diajarkan kepada generasi selanjutnya. Sebagian pandangan kelompok ateis terhadap salah satu agama misalnya, didalam Islam bahwa yang tidak mematuhi perintah tuhan mereka akan terkena hukuman dan bagi siapa yang patuh terhadap peraturan tuhan maka akan mendapatkan reward sendiri. Contoh lagi dari banayak agama, tetang adanya surga dan neraka, bahwa kehidupan setelah mati akan ada yang mendapatkan surga dan neraka, yang kemudian ada lagi bahwa tuhan akan membenci dan menghukum ciptaaannya dan banyak lagi.

Melihat konteks tersebut para penolak tuhan berfikir bahwa kenapa kelompok-kelompok yang beragama mereka mengikuti sesuatu atau tuhan yang kejam, dan tidak ada kebaikan tampa real kebenarannya, dalam artian kelompok ateis ini berfikiran mengapa seorang manusia yang memiliki keyakinan tentang ketuhanan 
mereka mau-mau saja mengikuti semua apa yang dituntutkan oleh tuhan dan mau menanggung konsekuensi bertuhan, yang mana semua manusia itu memiliki kebebasan tanpa ada penciptaan. Hukuman ataupun aturan-aturan tentang kehidupan yang menimpa pada diri kelompok -kelompok yang memiliki keyakinan tuhan. Selain itu kelompok ateis mengira kenapa orang-orang yang bertuhan dan meyakini adanya jiwa mau menggorbankan hidupnya demi keyakinan tentang adanya tuhan, jiwa ataupun roh, mereka juga sudah menyianyiakan kehidupan mereka dengan berpengang dengan yang namanya tuhan, apalagi tuhan-tuhan yang tidak bisa ditangkap dengan panca indra, semua itu adalah adalah hal yang merugikan bagi kaum ateis ini.

Kelompok tersebut tidak mengangap bahwa jiwa dari suatu haq itu tidak ada dan tidak benar adanya, dan melihat semua itu nol dan gimanapun keadaannya tetep nol dan nol dalam artian tidak ada dan pasti tidak jelas wujud dan keberadaannya, dan mengapa memikirkan sesuatu yang tidak nyata adanya. Pada intinya berbagai pendapat atheis pada dasarnya menganggap bahwa dunia sudah ada dengan sendirinya. Sesuatu macam seperti itulah yang telah memberikan suatu anggapan bahwa alam semesta ini tidak mempunyai adanya pencipta, ataupun pemelihara, sehingga tuhan itu tidak belaku pada keyakinannya. Bahwasanya argument mereka itu didasarkan pada kenyataaan yang rasional.

Fenomena yang ada dengan keadilan tuhan memperkuatan mereka bahwasannya tuhan itu hanyalah suatu proyeksi dari diri manusia sendiri, yang dalam artian wujud tuhan itu hanyalah anggapan manusia yang merupakan rancangan yang didasarkan pada hasil pemikiran baik melalui pengalaman lahiriah maupun batiniah.

\section{Argumentasi Evolusi Agama}


Kemudian ada pemikiran lain tentang evolusi agama ini menunjukkan agama bukan datang dari tuhan namun muncul dari pemikiran dan perasaan.

Pandangan yang pertama adalah tentang evolusionisme merupakan suatu konsep yang menyatakan bahwa adanya suatu proses dari keyakinan yang sangat simpel yang akhirnya hal tersebut menjadi mengembang dan sempurna. Menurut asumsi evolusionisme yang pertama yaitu dinamisme.

Pemahaman dinamisme, manusia dari masa primitive itu suda mengakui tentang keberadaan kekuatan yang berpengaruh pada kehidupan. kelompok ini secara tidak langsung mengakui tentang adanya suatu kekuatan dan jiwa. Pada mulanya pengaruh tersebut tertujukan pada benda, jadi setiap benda itu berpengaruh pada manusia. Mereka percaya bahwa suatu benda itu terdapat suatu jiwa ataupun roh mempengaruhi pada kehidupan mereka. Pada benda-benda tersebut ada pengaruh positif dan negative pada manusia dan kekuatan yang ada dibenda tersebut itu berbeda-beda. Menurut mereka meskipun tidak dapat dirasakan dengan indra, tetapi pengruhnya dapat dirasakan. Dalam artian semua benda yang disekelilingya itu memilki suatu kekuatan yang berbeda-beda yang tak dapat ditangkap dengan indra namun bisa mereka rasakan.

Kemudian keyakinan animisme mempercayai bahwa adanya peran suatu roh atau jiwa dalam kehidupannya, jadi setiap benda yang dianggapnya baik itu mempunyai roh. Kemudian Pada orang primitif, jiwa atau roh dipercaya sebagai sesuatu yang aktif meskipun apa terdapat pada benda itu telah tiada, oleh karenanya jiwa atau roh, dianggap sebagai sesuatu yang selalu hidup dan tidak pernah mati, kemudian jiwa ataupun roh dianggap mempunyai rasa, seperti senang atau sebaliknya, ketika apa yang diinginkannya itu tidak tercapai dan tidak terpenuhi. Melihat itu semua bisa diringkaskan 
bahwa mereka masih mempunyai pegangan dan kepercayaaan tentang adanya suatu exsistensi ketuhanan.

Kemudian yang ketiga adalah polyteisme, mereka menganggap bahwa kepercayaan animism dan dinamisme itu lama kelamaan tidak menimbulkan kepuasan, karena menurut mereka hal tersebut sangat banyak yang menjadi pujian serta pemujaan. Pandangannya tentang suatu jiwa yaitu roh yang lebih dari lainnya itulah yang disebut dewa dan dewa tersebut memilki tugas masingmasing yang mana para dewa yang diakuinnya diadakan semacam seleksi, jadi secara tidak langsung mereka menganggap exsistensi ketuhanan mereka jalankan dengan cara mereka sendiri dalam artian sesuai dengan kemauannya mereka sendiri, karena mereka anggap tidak mungkin mempunyai kekuasaan yang sama, yang akhirnya lama kelamaan kelompok menunjuk satu dewa yang nantinya akan mereka jadikan tuhan, namun mereka masih, mengakui tuhan lain.

Yang kemudian kelompok yang menganggap satu tuhan berbangsa tersebut inilah yang namanya henoteisme. Selanjutnya yang terakhir yaitu pemikiran yang mengakui satu tuhan saja dan tuhan tersebut untuk seluruh bangsa dan berlaku internasional kelompok inilah yang disebut dengan monoteisme. Kelompk monoteisme ini berbeda pemikiran dengan kelompok poloystisme. Mereka hanya berpengangan pada satu tuhan saja yang nantinya mengatur pada kehidupan mereka. Kedua kelompok ini yaitu monoteisme dan poloytisme masih dianggap dalam suatu kelompok yang masih mengakui tentang adanya tuhan dan menganganggap wujud tuhan itu masih berpengaruh da nada ikut campur di dalam kehupannya, namun memang tentang jumlah ketuhanan yang berbeda.

\section{Evaluasi}


1. Baca teks ini dengan seksama, kemudian lakukan paraphrase (encoding) di setiap sub babnya!

2. Buat sebuah komentar menggunakan Thesis annotation, The probe annotation, Personal view annotation, dan Inventive annotation terhadap teks di atas untuk mengomentari setiap sub-babnya!

3. Buat kelompok diskusi setiap kelompok terdiri dari 5 orang mendiskusikan masalah-masalah berikut dan tuliskan hasil diskusinya:

a. Problem hal-hal yang ghaib

b. Evolusi agama

\section{Referensi}

Broad, C. D. "Arguments for the Existence of God," Journal of Theological Studies 40 (1939): 16-30; 156-67. Retrieved September 20, 2007.

Cell, Edward. Language, Existence, and God. New York: Abingdon Press, 1971. ISBN 0687210631

Cohen, Morris R. "The Dark Side of Religion," Religion Today, a Challenging Enigma, ed. Arthur L. Swift, Jr. (1933). Revised version in Morris Cohen, The Faith of a Liberal (1946). Retrieved September 20, 2007.

Haisch, Bernard. The God Theory: Universes, Zero-Point Fields and What's Behind It All. San Francisco: Red Wheel/Weiser Books, 2006.

Hume, David. 1779. Dialogues Concerning Natural Religion. Edited by Richard Popkin. Indianapolis: Hackett, 1998.

Mackie, J. L. The Miracle of Theism. Oxford: Oxford University Press, 1982. ISBN 019824682X

Nielson, Kai. Ethics Without God. London: Pemberton Books, 1973. Paley, William, 1802. Natural Theology. Indianapolis: Bobbs-Merrill, 1963. 


\section{TEKS IV}

\section{PEMBUKTIAN WUJUD ALLAH}

Filsafat wujudi mencakup segala sesuatu. la mengandaikan ketidakterbatasan. Sebagai konsekuensinya adalah bahwa wujud Tuhan itu niscaya/ada/mutlak. Secara definisi, sebgaimana diutarakan oleh Taqi Misbah Yazdi dalam buku Filsafat Islam,subjek filsafat pertama atau metafisika adalah "mawjud mutlaq" atau mawjud huwa mawjud (al - mawjud bi ma huwa mawjud)..

Para ulama kalam dan para filsuf Yunani atau filsuf Islam mereka bersepakat bahwa urgensi akal menetapkan keberadaan Tuhan. Oleh karena itu dapat dikatakan keberadaan Tuhan adalah persoalan yang sangat penting dan fundamental dalam kajian keilmuan Islam.

Pembahasan mengenai al - Wujud atau ada merupakan suatu konsep yang abstrak. Karena itulah, ada bebrapa pendapat menanggapi hal tersebut. Satu caranya adalah menganggap bahwa "wujud" tidak bisa didefinisikan atau ditangkap akal manusia, tetapi hanya bisa langsung ditangkap oleh intuisi intlektual. Hal ini mungkin dapat diterima oleh akal segelintir orang saja, tetapi apakah "Ada"nya Tuhan juga demikian?

\section{Menurut al-Kindi}

Dalam pembuktian adanya Tuhan al-Kindi mengajuan beberapa argumen, pertama berdasarkan prinsip hokum sebab akibat, setiap yang tercipta pasti ada yang mencipta dalam hal ini yang dimaksud sang pencipta adalah Tuhan. Ketika Tuhan sebagai sang pencipta dan semesta ada, maka tentunya ia ada.

Kedua, bersarkan prinsip bahwa segala sesuatu (alam semesta) tida bisa menjadi sebab atas dirinya sendiri, karena supaya 
menjadi sebab atas dirinya maka sesuatu harus ada sebelum dirinya. Maksudnya adalah jika alam semesta tidak bisa ada karena dirinya sendiri berarti ia butuh sesuatu di luar dirinya untuk menunjukkan dirinya ada. Dan itu adalah tuhan.

Ketiga, berdasarkan analogi antara alam semesta dan manusia. Menurut argument ini, sama halnya tubuh manusia yang bergerak dan berfungsi secara teratur yang menunjukkan adanya sang pengatur tidak kelihatan yakni jiwa. Hal demikian juga dengan alam. Perjalanan alam yang teratur dan searas menunjukkan adanya sang pengatur yang tidak kealihatan yakni Tuhan. Karena itu al-Kindi mengatakan bahwa keberadaan Tuhan dapat dietahu melalui efekefek pengaturannya yang bijak sebagamana yang terwujud dalam alam semesta.

Keempat, didasarkan argument teleologis yaitu dalil alInayah, dalil ini menyatakan bahw semua gejala alam tidak mungkin terjadi secara kebetulan tetapi pasti karena adanya tujuan dan maksud tertentu, seta menunjukkan adanya Zat Yang Maha Mengatur. Al-Kindi menulis

"susunan alam dan keteraturannya yang mengagumkan, di mana setiap bagian selaras dengan bagian lainnya, beberapa bagian tunduk paada pengaturan bagian lainnya: juga pengaturannya yang sempurna, di mana yang terbaik selalu terpelihara dan yang terburuk senantiasa terbinnasakan, semua adlah petunjuk yang paling baik dan jelas tentang adnya system pengaturan yang sangat cerdas, yang dengan demikian menunjukkan adanya Sang Maha Pengatur yang sangat cerdas" "keteraturan, ketertiban, dan keselarasan alam raya ini adalah wujud dari pengaturan-Nya yang bijak dan sempurna. Sungguhkehdupan alam yang serba terartur dan bijka telah cukup (sebagai bukti tentang ada-Nya) bagi mereka yang mampu melihat dengan pikiran jernih". 
Argumen ini, oleh sebagian filsuf, dianggap sebagai dalil yang efektif untuk membuktikan adanya Tuhan. dalil ini digunakan Ibn Rusyd (dalam filsafat islam). Dan dipakai oleh Immanuel Kant (dalam tradisi filsafat Barat)

\section{Al- Farabi}

Menurut Al-Farabi, sifat alam mumkin wujudnya dan oleh sebab itu berhajat pada suatu zat yang bersifat wajib wujudnya bersifat wajib, untuk merubah kemungkinan wujudnya kepada wujud hakiki; yaitu sebab bagi terciptanya wujud yang mungkin itu. Runtutan sebab musabab tak boleh tidak mesti mempunyai kesudahan, dan mempunyai kesudahan karena itu perlu ada sesuatu zat yang wujudnya bersifat wajib dan tak sendiri, ada semenjak dulu, tidak berubah dari satu hal ke hal lain. Semata-mata akal. Dialah sebab pertama dari segala yang ada, Tuhan satu dan ia disebut Allah

Mengenai pembuktian adanya Tuhan, al-Farabi mencoba dengan membuat kerangka pemikiran mengenai wujud dan membaginya menjadi dua. Menurutnya segala yang ada hanya dua itu saja tidak ada yang lain. Kedua Bagian tersebut yaitu:

\section{1) Wajib al-Wujud}

Wajib al-Wujud maksudnya wujud Allah wajib ada dengan sendirinya. Tuhan merupakan wujud yang kekal, tidak di dahului oleh tiada. Mustahil jika wujud ini tidak ada. seperti cahaya matahari ada karena sebab adanya matahari. Cahaya tersebut bisa ada atau tidak ada. Maksud dari Wajibu I-Wujud adalah jika dilihat dari zatnya ia wajib adanya tanpa bergantung pada yang lain, dia adalah Yang Maha Esa yaitu Tuhan

2) Mumkin al-Wujud 
Mumkin al-Wujud yaitu wujud yang ada bukan karena sebab lainnya melainkan karena dirinya sendiri. la adalah sebab pertama bagi wujud-wujud lainnya. Dengan begitu keberadaan Allah menjadi wajib adanya, wujud yang pertama ini adalah Tuhan (Allah). menurut Al-Farabi, zat yang sempurna mustahil tidak ada dari segala apapun yang ada. Bahkan ia adalah qadim, abadi dan otonom. Pengertian mukmin al - wujud adalah, jika dilihat dari zatnya Tuhan tidak wajib adanya dalam kenyataan dengan sendirinya, tapi karena adanya sebab di luar dirinya (yang menjadikannya yaitu Tuhan)

Konsep mungkin Al-Farabi berdalil untuk membuktikan adanya Allah, konsep ini didasarkan pada aktivitas akal. Tidak melihat kepada kenyataan empiris yang selalu berubah-ubah sebagai tanda ia baru. Untuk membuktikan keesaan Tuhan, Al-Farabi menggunakan teori emanasi. Menurut Al-Farabi alam ini memancar dari Tuhan melalui akal-akal yang jumlahnya sepuluh. Antara alam materi dan Tuhan terdapat perantara. Tuhan berpikir tentang diri-Nya, dan dari pemikiran-Nya ini memancarlah Akal Pertama. Akal pertama berpikir tentang Tuhan, dan dari pemikiran-Nya ini timbullah Akal Kedua. Akal ini berpikir tentang Tuhan dan timbullah Akal Ketiga, dan demikian seterusnya sehingga terwujudlah Akal Kesepuluh

Akal Pertama berpikir tentang dirinya dan dari pemikirarn tersebut timbullah langit pertama. Akal-akal lainnya juga berpikir tentang dirinya masing-masing. Dari pemikiran-pemikiran tersebut timbullah planet-planet, seperti Saturnus, Jupiter Mars, Matahari, Venus, Mercuri, Bulan, Bumi serta segala yang ada di dalamnya. Dengan cara demikian, maka Tuhan tidak mempunyai hubungan langsung dengan alam, Tuhan jauh dari alam materi yang mengandung arti banyak.

Yang Esa, yaitu Tuhan itulah yang dikemukaka oleh Al-Farabi,. TuhanAda dengan sendiri-Nya. Karena itu, la tidak memerlukan yang 
lain lagi untuk ada-Nya atau keperluan-Nya. Tuhan mampu mengetahui Diri-Nya sendiri, mengerti dan dapat dimengerti. Tuhan itu sangat unik, karena sifat-Nya demikian. Tak ada yang sama dengan-Nya, serta tidak memiliki lawan atau persamaan.

Berdasarkan kerangka berfikir diatas, Al-farabi membahas masalah wujud ketuhanan beserta sifat-sifatNya. Al-farabi juga membicarakan masalah kejadian alam semesta dengan menggunakan teori emanasi. Menurutnya hakikat Allah ialah wujud yang sempurna yang ada tanpa perantara atau sebab lainnya. Maksudnya, bahwa ia merupakan wujud yang sempurna yang ada tanpa perantara atau sebab lainnya. Mengenai sifat Tuhan Al-farabi mengungkapkan bahwa sifat Tuhan itu tidak berbeda dengan zatNya. Tuhan bersifat tunggal karena Tuhan tidak menempati ruang dan waktu tapi keberadaannya ada

\section{Ibnu Sina}

Ibnu Sina berpendapat akal Pertama mempunyai dua sifat; Pertama, sifat wajib wujudnya, sebagai pancaran dari Allah. Kedua, sifat mungkin wujudnya jika ditinjau dari hakikat dirinya. Dengan demikian ia mempunyai tiga obyek pemikiran: Tuhan, dirinya sebagai wajib wujudnya dan dirinya sebagai mungkin wujudnya. Dari pemikiran tentang Tuhan, timbul akal-akal, dari pemikiran tentang dirinya sebagai wajib wujudnya timbul jiwa-jiwa dan dari pemikiran tentang dirinya sebagai mungkin wujudnya timbul langit-langit.

Mengenai adanya tuhan, Ibnu Sina tidak mencari dalil dengan salah-satu makhluknya, tetapi dengan dalil wajib al-wujud. Sedangkan mengenai jagad raya ia menggunakan dalil mumkin alwujud, karena jagad raya memerlukan sesuatu harus ada sebab ('illat) sehingga berupa wujud, hal ini karena wujud Allah tidak dari zat-Nya sendiri. 
Ibnu Sina membagi wujud ke dalam 3 bagian, yaitu

1. Niscaya ada (wujud wajib)

2. Mungkin ada dan tidak (wujud mungkin)

3. wujud mustahil.

Pertama, Wujud wajib menurut Ibnu Sina adalah esensi yang tidak selalu memiliki wujud, namun keberadaannya tidak dapat dipisahkan dari wujud. Esensi ini tidak dimulai dari ketiadaan dan kemudian terwujud, tetapi ia wajib dan mesti berwujud selamalamanya. Wujud wajib menjadi sebab bagi eksistensi yang mungkin

kedua, Wujud mungkin itu meliputi segala sesuatu yang ada di alam semesta ini selain Allah SWT.Keberadaan wujud mungkin selalu bergantung pada adanya wujud wajib, karena tanpa adanya wujud wajib, maka akan terjadi daur dan tasalsul, dan sudah pasti mustahil adanya. Sehingga teori ini yang digunakan oleh Ibnu Sina dalam pembuktian keberadaan Tuhan.

ketiga, wujud mustahil adalah esensi yang tidak dapat mempunyai wujud, karena keberadaannya yang tidak dapat terbayangkan oleh akal. Seperti adanya sekarang ini.

\section{Ibnu Rusyd}

Dalam masalah ketuhanan, Ibn Rusyd berpendapat bahwa Allah adalah Penggerak Pertama (muharrik al - awwal). Sifat positif yang dapat diberikan kepada Allah ialah "Akal" dan "Ma'qul. wujud Allah ialah Esa-Nya. Wujud dan ke-Esaan tidak berbeda dari zat-Nya. Menurutnya istilah wujud menunjuk pada sesuatu (al-asyya') yang mengacu pada bermacam arti yaitu :

1. bisa berarti sebab (al-illah) yang mendahuluinya atau pegetahuan (al-ilm) yang berkaitan dengan suatu jenis tertentu. Misal kata api sebagai penyebab bagi segala 
sesuatu yang panas. Jadi kata panas menunjukkan segala sesuatu yang membara

2. esensi (Al-mahiyah) seperti yang dikemukakan oleh alFarabi

3. menunjuk kepada kata yang benar atau logis seperti yang disampaikan oleh ibnu sina

Ibnu Rusyd sepakat dengan al-Farabi bahwa sesuatu yang ditunjuk dalam istilah wujud adalah realitas sesuatu bukan pada sebab apalagi kata logis. Menurut Ibn Rusyd untuk membuktikan adanya Tuhan yaitu dengan menggunakan :

1. Dalil inayah al-Ilahiyah (pemeliharaan Tuhan)

Dikemukakan bahwa alam dan seluruh isinya sesuai dengan kehidupan manusia. Persesuaian ini tidak mungkin terjadi secara kebetulan, tapi menunjukkan adanya pencipta yang sangat bijaksana. semua kejadian dalam alam sangat cocok dengan fitrah manusia, seperti adanya siang, malam, matahari, bulan, tumbuh-tumbuhan, hewan dan anggota tubuh manusia, tidak mungkin terjadi dan terpelihara tanpa pencipta dan bijaksana. Dalil inayah bersumber dari dua hal utama.

a) Seluruh yang al - maujudat (yang ada) selaras bagi keberadaan manusia.

b) Keselarasan tentunya tidak terjadi secara kebetulan. Keselasan itu meniscayakan adanya sebab yang sengaja mengarahkan untuk tujuan tertentu. Sebab mustahil keselarasan akan terjadi bila hanya berasal dari suatu proses kebetulan

2. dalil ikhtira' (dalil penciptaan) 
Yang termasuk dalam dalil ini ialah wujud segala macam sesuatu yang ada di alam semesta seperti hewan, tumbuh-tumbuhan, langit dan bumi. Segala maujud ini adalah diciptakan harus ada yang menciptakan.

\section{3. dalil harakah (gerak).}

Alam semesta ini bergerak dengan gerakan yang abadi. Adanya gerakan ini menunjukkan adanya sang penggerak yang tidak bergerak dan bukan benda, yakni Tuhan. Dalam dalil ini dijelaskan bahwa setiap yang digerakkan pastilah memiliki penggerak. Sebab tidak pernah didapatkan sesuatu yang bergerak dari diriya sendiri. Bukti gerak ini ada tiga unsur utama yaitu :

a) setiap yang digerakkan baik berdasarkan zatnya maupun tidak adalah terbagi dan memiliki bagian-bagian.

b) jika diandaikan setiap bagian dari penggerak pertama itu tidak bergerak maka niscaya ia memerlukan penggerak selain dirinya. Jadi penggerak dalam bagian itu adalah penggerak yang tidak tergerakkan itulah Penggerak Utama (Allah swt)

\section{Evaluasi}

1. Baca teks ini dengan seksama, kemudian lakukan paraphrase (encoding) di setiap sub babnya!

2. Buat sebuah komentar menggunakan Thesis annotation, The probe annotation, Personal view annotation, dan Inventive annotation terhadap teks di atas untuk mengomentari setiap sub-babnya!

3. Buat kelompok diskusi setiap kelompok terdiri dari 5 orang mendiskusikan masalah-masalah berikut dan tuliskan hasil diskusinya: 
a. Bukti adanya Tuhan perspektif Al-Kindi

b. Bukti adanya Tuhan perspektif Al-Farabi

c. Bukti adanya Tuhan perspektif Ibnu Sina

d. Bukti adanya Tuhan perspektif Ibnu Rusyd

\section{Referensi}

Al-Farabi, Abu Nashr. Araa'u Ahli I-Madinah Al-Fadilah Wa Madhadatuha. Edited by Ali bu Mulham. 1st ed. Beirut: Dar wa Maktabah Al-Hilal, 1995.

- - Kitabu S-Siyasah Al-Madinah. Edited by Ali bu Mulham. Beirut: Dar wa Maktabah Al-Hilal, n.d.

Ibnu Sina, Abu 'Ali Al-Husain. Al-Risalah Al-'Arshiyyah Fi Tawhidihi Ta'Ala Wa Sifatuhu. 1st ed. Omman: Matabi' Dairah al-Ma'arif al'Amaniyyah, 1934.

- - . An-Najah Fii I-Mantiq Wa I-Ilahiyyat. Edited by Majid Fakhry. Beirut: Daru I-Afaq Al-Jadidah, 1982.

Rusyd, Ibnu. Al-Kasyf Fi Manahiji I-Adillah Fi Aqa'idi I-Millah,. Edited by Muhammad Abid Al-Jabiri. 1st ed. Beirut: Markaz Daru I-Wihdah Al-Arabiyyah, 1998. 


\section{TEKS V}

\section{NALAR SAINS DALAM MENYINGKAPI}

\section{ADA ATAU TIDAK ADA NYA TUHAN}

Meski definisinya sampai saat ini masih diperdebatkan dikalangan tokoh agama dan saintis, "Keyakinan" masih menjadi salah satu tema penting yang tak lekang oleh waktu dan terus dibicarakan karena spektumnya yang amat luas. Terutama dalam membangun kritis komunikasi tentang keberadaan Tuhan dan menghubungkannya dengan fenomena di dunia sains.

Asal-usul kepada Allah berasal dari pengalaman manusia yang baru muncul di bumi dan tidak memiliki asal usul ilham ilahi. Jika kita berpikir tentang seperti apa kondisi saat pembentukan bumi, tampaknya semua lebih ajaib bahwa kehidupan bisa menjadi tidak ada sama sekali. Dalam bentuk ini bergeser. Tuhan berdamai dengan sains. Kesenjangan yang diisi hanya menguatkan adanya bukti Tuhan, daripada menyingkirkannya. Lalu bagaimana pandangan para tokoh sains terhadap keyakinan terhadap Tuhan? Inilah yang akan penulis telusuri dari berbagai perspektif sains dan beberapa makalah tentang keyakinan terhadap Tuhan.

\section{Pengertian Sains}

Sains adalah sebuah ilmu pengetahuan yang memepelajari tentang berbagai fenomena yang ada di alam semesta ini. Sains adalah ilmu pengetahuan dan dalam mencapainya harus memiliki suatu kebenaran melalui proses atau sebuah studi yang di uji melalui metode ilmiah atau sering di sebut sains adalah sebuah pengetahuan yang diperoleh melalui sebuah pembelajaaran dan pembuktian. Sains memiliki ciri-ciri sebagai berikut 
a. Objek kajian ilmu sains berupa benda-benda yang konkret

b. Sains mengembangkan pengalamannya melalui pengalaman yang bersifat empiris

c. Langkah-langkah yang digunakan sains yaitu menggunakan langkah yang sistematis

d. Cara berfikir sains yaitu dengan cara yang logis

e. Hukum yang di hasilkan yaitu bersifat universal

f. Produk yang di hasilkan oleh sains bersifat objektif

\section{Nalar Sains dalam Menyikapi ada tidaknya Tuhan}

Fenomena sains dan agama islam mempunyai beberapa respons dari kalangan umat islam ada beberapa kalangan dari umat islam dalam menyikapinya. Secara umum mereka menerima adanya ilmu sains dengan cara mengamati ilmu sains dan menghubungkan nya ke dalam agama islam. Dan ada juga beberapa dari kalangan umat islam yang menolak adanya sains atau saling bertentangan satu sama lain. Dan yang terakhir mereka mencoba memberikan suatu celah atau jarak antara sains dan agama yang sering disebut dengan "islamisai sains"

Asal usul keyakinan pada Tuhan tampaknya dari usaha menjelaskan pengalaman manusia tentang hal-hal baru dan peristiwa-peristiwa yang diluar kebiasaan alam (bencana alam misalnya). Tuhan ada sebagai pengisi celah atas hal-hal tersisih dan abnormal di alam. Jevons menyebutkan kalau Tuhan diawali dengan usaha menjelaskan ketidakteraturan dan kejadian yang bersifat kebetulan. Kemunculan Tuhan untuk menjelaskan sebab-sebab fenomena fisikal ini memang tidak bersifat sakral. Max Muller berpendapat kalau tidak ada beda yang besar antara Agni, sang dewa api, dengan konsep eter yang dipakai fisikawan masanya untuk 
menjelaskan fenomena optika. Sakralitas baru datang ketika idetentang Tuhan dibawa ke ranah sosial-politik

Bukti terbesar tentang Allah di hadapan kita adalah ciptaanNya. Alam itu sendiri dan studi kita tentang alam, keduanya menyatakan fakta bahwa ada satu Tuhan yang, dalam ketidakterbatasan Kebijaksanaan-Nya, telah menciptakan dan terus mempertahankan alam semesta ini. Dengan mengabaikan atau menolak kebenaran ini, kita menceburkan diri ke dalam jurang ketidakpahaman yang suram dan kejahatan yang menyertainya. Keberadaan jagat raya ini, dengan pengorganisasiannya yang luar biasa dan kebermaknaannya yang tak terukur, tidak dapat dijelaskan kecuali telah diciptakan oleh Pencipta - Makhluk dengan kecerdasan tak terbatas alih-alih dengan kekuatan buta. Di antara para filsuf zaman kita, ada satu kelompok, mungkin untungnya yang kecil, yang meragukan keberadaan segala hal, tidak peduli apa pun itu. Ini menegaskan bahwa tidak ada manusia maupun alam semesta.

Dalam nihilismenya, ia juga menolak keberadaan Tuhan, bahkan sebagai kemungkinan yang jauh. Sejauh ini merek agnostisisme yang bersangkutan, ini mungkin menjadi titik filosofis yang layak dipertimbangkan murni sebagai latihan abstrak dalam logika, tetapi tidak ada hubungannya dengan kenyataan. Ketika kita berpikir, tindakan berpikir itu memberi bukti keberadaan kita. Filsuf dan matematikawan Prancis terkenal Descartes (1596-1660), mendirikan filosofinya pada sila: "Saya pikir, oleh karena itu, saya Dan dari titik ini, ia melanjutkan untuk menyimpulkan keberadaan am. Tuhan. Persepsi indera kita juga memberikan kejelasan indikasi.

Keberadaan eksternal hal-hal material. Jika misalnya saat berjalan di sepanjang jalan kita ditabrak batu, kita merasakan sakit. Pengalaman ini menetapkan bahwa, terlepas dari kita dan di luar kita, ada dunia yang memiliki identitasnya sendiri-sendiri. Kenyataannya, 
pikiran kita, melalui indera kita, merasakan objek yang tak terhitung banyaknya dan mencatat sensasi dan kesan yang tak terhitung jumlahnya setiap saat dari keberadaan kita yang terjaga. Tindakantindakan kognisi ini adalah pengalaman pribadi yang terus-menerus memperkuat konsep dunia yang memiliki eksistensinya sendiri. Sekarang, jika kecenderungan filosofis dari individu tertentu membuatnya skeptis tentang keberadaan alam semesta, ini adalah kasus yang luar biasa, tidak ada hubungannya dengan pengalaman jutaan manusia. Sederhananya individu semacam itu begitu asyik dengan kecenderungan pribadinya sendiri sehingga ia menjadi tuli dan buta terhadap realitas umum. Demi argumen, dia ingin agar kita mengakui maksudnya, tetapi ini sama sekali tidak menyiratkan bahwa Tuhan tidak ada.

Dengan adanya absurditas argumen terhadap keberadaan hal-hal yang diterima secara umum begitu paten sehingga hampir tidak layak untuk dikomentari. Dan terlepas dari tidak dapat dipahami oleh orang awam, mereka tidak pernah bisa mendapatkan kepercayaan di dunia pembelajaran.

Di luar kelompok nihilis, keberadaan alam semesta diterima sebagai kenyataan: pada saat kita mengakui keberadaannya, kita menemukan kepercayaan pada Tuhan yang tak terhindarkan, karena gagasan penciptaan muncul secara diam-diam karena tidak ada yang tidak dapat dibayangkan. Ketika segala sesuatu besar atau kecil, memiliki sebab, bagaimana bisa dipercaya bahwa alam semesta yang begitu luas telah muncul dengan sendirinya, dan bahwa ia tidak memiliki Pencipta.

Persepsi indera kita juga memberikan kejelasan indikasi keberadaan eksternal hal-hal material. Jika misalnya saat berjalan di sepanjang jalan kita ditabrak batu, kita merasakan sakit. Pengalaman ini menetapkan bahwa, terlepas dari kita dan di luar kita, ada dunia 
yang memiliki identitasnya sendiri-sendiri. Kenyataannya, pikiran kita, melalui indera kita, merasakan objek yang tak terhitung banyaknya dan mencatat sensasi dan kesan yang tak terhitung jumlahnya setiap saat dari keberadaan kita yang terjaga.

Tindakan-tindakan kognisi ini adalah pengalaman pribadi yang terus-menerus memperkuat konsep dunia yang memiliki eksistensinya sendiri. Sekarang, jika kecenderungan filosofis dari individu tertentu membuatnya skeptis tentang keberadaan alam semesta, ini adalah kasus yang luar biasa, tidak ada hubungannya dengan pengalaman jutaan manusia. Sederhananya individu semacam itu begitu asyik dengan kecenderungan pribadinya sendiri sehingga ia menjadi tuli dan buta terhadap realitas umum. Demi argumen, dia ingin agar kita mengakui maksudnya, tetapi ini sama sekali tidak menyiratkan bahwa Tuhan tidak ada. Adanya absurditas argumen terhadap keberadaan hal-hal yang diterima secara umum begitu paten sehingga hampir tidak layak untuk dikomentari.

Sains tidak punya penjelasan untuk fakta-faktanya, dan mengatakan bahwa secara tidak disengaja bertentangan dengan matematika. Kita harus mengakui bahwa ada banyak sekali fakta di dunia ini dan alam semesta, yang tidak dapat dijelaskan kecuali kita mengakui campur tangan pikiran yang unggul. Misalnya, kepadatan es kurang dari air, karena karena saat membeku, volume meningkat sehubungan dengan massanya. Itulah sebabnya es mengapung dan bukannya tenggelam ke dasar danau dan sungai dan secara bertahap membentuk massa yang padat. Di permukaan air, terbentuk lapisan penyekat untuk mempertahankan air di bawahnya pada suhu di atas titik beku. Dengan demikian, ikan dan berbagai bentuk kehidupan laut lainnya dapat tetap hidup sepanjang musim dingin, dan, ketika musim semi tiba, es itu mencair dengan cepat

\section{Tuhan Menurut para Saintis}




\section{a. Tuhan Menurut John Stuart Mill}

Dalam autobiografinya, John Stuart Mill, mengamati bahwa ayahnya telah membuatnya terkesan sejak awal, bahwa cara dunia muncul menjadi subjek yang tidak diketahui apa-apa: bahwa pertanyaan "Siapa yang menciptakan ku?" pertanyaan ini tidak dapat dijawab, karena kita tidak memiliki suatu pengalaman atau sebuah bukti yang begitu kuat yang dapat digunakan untuk menjawab pertanyaan tersebut, dan bahwa jawaban apa pun hanya akan menambah kesulitan, karena pertanyaan segera muncul dengan sendirinya, "siapa yang menciptakan Tuhan?" Ini adalah sebuah penjelasan lama yang telah banyak digunakan oleh kaum atheis, keterlibatan nya adalah bahwa jika kita menerima adanya Pencipta alam semesta, maka kita akan dipaksa untuk menerima Pencipta ini sebagai abadi.

ketika Tuhan harus dianggap abadi, mengapa alam semesta itu sendiri tidak dianggap abadi? Walaupun kesimpulan semacam itu sama sekali tidak ada artinya. Karena tidak adanya sebuah tanda alam semesta seperti itu yang telah terungkap sejauh ini untuk membenarkan kesimpulan bahwa alam semesta telah muncul dengan sendirinya hingga abad ke-19, argumen menyesatkan dari para atheis ini adalah dianggap sebagai yang paling menarik. Tetapi sekarang, dengan ditemukannya hukum kedua termodinamika, argumen ini telah kehilangan validitasnya.

Termodinamika adalah sebuah cabang ilmu pengetahuan, yang berurusan dengan transformasi energi. Secara khusus, ini menunjukkan hubungan kuantitatif antara panas dan bentuk energi lainnya. Pentingnya konservasi dalam kaitannya dengan energi, dinyatakan dalam hukum pertama termodinamika. Hukum Entropi adalah hukum termodinamika kedua. Untuk memahaminya, mari kita ambil contoh batang logam, yang telah dipanaskan di satu ujung 
tetapi dibiarkan dingin di ujung lainnya. Panas akan segera mulai mengalir dari ujung panas sepanjang panjang batang ke ujung dingin, dan akan terus melakukannya sampai suhu seluruh batang menjadi seragam. Aliran panas akan selalu ke arah, mis. Dari yang lebih hangat ke yang lebih dingin, aliran ini tidak akan pernah terjadi, lewat secara spontan ke arah yang berlawanan, atau bahkan sembarangan ke arah mana pun.

\section{b. Tuhan Menurut Edward Luther Kessel}

Mengenai relevansi hukum-hukum ini dengan penciptaan, Edward Luther Kessel, seorang ahli zoologi Amerika, menulis: "Ilmu pengetahuan dengan jelas menunjukkan bahwa alam semesta tidak mungkin ada dari keabadian. Hukum entropi menyatakan bahwa ada aliran panas yang terus-menerus dari hangat ke hangat. tubuh yang lebih dingin, dan bahwa aliran ini tidak dapat dibalik untuk lewat secara spontan ke arah yang berlawanan. Entropi adalah rasio energi yang tidak tersedia terhadap yang tersedia, sehingga dapat dikatakan bahwa entropi alam semesta selalu meningkat. untuk saat ketika suhu akan seragam secara universal dan tidak akan ada lagi energi yang bermanfaat. Akibatnya, tidak akan ada lagi proses kimia dan fisik dan kehidupan itu sendiri akan lenyap. Tetapi karena kehidupan masih berlangsung, dan kimia dan fisik proses masih dalam proses, terbukti bahwa alam semesta kita tidak mungkin ada dari keabadian, kalau tidak maka akan lama kehabisan energi yang berguna dan terhenti. Oleh karena itu, akhirnya, ilmu pengetahuan membuktikan bahwa alam semesta kita memiliki permulaan. Dan dengan melakukan itu membuktikan realitas Allah, karena apa pun yang punya permulaan tidak dimulai dengan sendirinya tetapi menuntut Penggerak Utama, Pencipta, Tuhan.

\section{c. Tuhan Menurut James Jeans}


James Jeans telah mengutarakan pandangan yang sama sebagai berikut: " Pandangan ilmiah yang lebih resmi adalah bahwa entropi alam semesta harus selamanya meningkat sampai batas akhir nilai. Belum mencapai ini; kita seharusnya tidak memikirkannya jika ada. Itu masih meningkat dengan cepat, dan karenanya harus memiliki permulaan; dan pasti ada apa yang dapat kita gambarkan sebagai "ciptaan pada waktu yang tidak jauh." Ada banyak bukti fisik dari jenis ini untuk membuktikan bahwa alam semesta tidak selalu ada. Sebaliknya, rentang hidupnya terbatas. Menurut astronomi, alam semesta berada dalam kondisi ekspansi terus-menerus ke luar dari pusat asalnya.

Semua galaksi dan benda langit terlihat bergerak menjauh satu sama lain dengan kecepatan sangat tinggi. Fenomena ini dapat dijelaskan dengan memuaskan jika kita mengandaikan titik awal waktu ketika semua konstituen ini adalah keseluruhan yang terintegrasi, dan pelepasan energi berikutnya dan proses perkembangan gerakan. Atas dasar pengamatan yang berbeda dari jenis yang sama, umumnya diyakini bahwa alam semesta berasal sekitar 5 miliar tahun yang lalu. Secara teori, seluruh alam semesta terbentuk oleh ledakan luar biasa dari keadaan kepadatan tinggi dan suhu tinggi. Ini kemudian dikenal sebagai teori 'big-bang'. Menerima bahwa alam semesta memiliki rentang hidup yang terbatas.

Seperti alam semesta yang memiliki rentan waktu yang terbatas dan tidak kekal selamanya. Alam semesta adalah ruang yang tak terhingga luas di mana bintang-bintang yang tak terhitung jumlahnya terus bergerak dengan kecepatan luar biasa. Beberapa bintang bergerak sendiri-sendiri, beberapa dalam kelompok dua atau lebih, sementara bintang yang tak terhitung jumlahnya dikelompokkan dalam rasi bintang. Anda mungkin telah memperhatikan berjuta-juta partikel debu yang berputar-putar 
dalam cahaya yang menembus ruangan melalui beberapa lubang. Jika Anda dapat memvisualisasikan pemandangan yang sama ini dalam skala kolosal, Anda akan memiliki gambaran kasar tentang revolusi bintang-bintang di seluruh alam semesta. Satu-satunya perbedaan adalah partikel debu dapat bertabrakan dan bergerak dalam kombinasi sedangkan bintang-bintang. meskipun jumlah mereka yang sangat besar berada pada jarak yang tak terukur satu sama lain dan mengikuti jalur masing-masing, seperti kapal yang berlayar ratusan mil secara terpisah dalam luasnya samudera. Seluruh alam semesta terbuat dari rasi bintang yang tak terhitung jumlahnya, atau galaksi, yang semuanya bergerak terus menerus. Contoh terdekat dari gerakan tersebut adalah bulan berputar-putar di bumi pada jarak 240.000 mil. Ini menyelesaikan setiap revolusi dalam 29,5 hari. Demikian pula, bumi kita, pada jarak 95 juta mil dari matahari, berputar pada sumbunya pada seribu mil per jam, dan membutuhkan satu tahun penuh untuk mengelilingi matahari.

Yang sekarang diperdebatkan oleh para geolog adalah laju terbentuknya lautan. Apakah uap air semuanya mendesis dalam waktu satu miliar tahun atau kurang, sehingga laut memiliki ukuran yang sekarang sejak kehidupan dimulai? Atau prosesnya telah begitu lambat sehingga laut telah tumbuh sepanjang waktu geologis dan masih tetap tumbuh? Mereka yang mempertahankan occan terbentuk di awal permainan dan telah stabil dalam ukuran untuk waktu yang lama, menunjukkan bahwa benua tampaknya menjadi fitur permanen bumi. Mereka tidak tampak telah jauh lebih besar di masa lalu, ketika laut itu seharusnya, jauh lebih kecil. Di pihak lain, para penguasa lautan sudah semakin membesar dan menunjukkan bahwa letusan gunung berapi bahkan sekarang menguapkan sejumlah uap air ke udara; Uap air berasal dari batuan dalam, bukan dari laut. Juga, ada gunung-gunung laut di bawah pasifik dengan puncak-puncak datar yang mungkin pernah berada di tingkat laut tapi 
sekarang ratusan meter di bawah. 9 jadilah bahwa sebagaimana mungkin, jika lautan telah lebih dalam hanya beberapa meter lagi, mereka akan menyerap semua karbon dioksida dan oksigen yang tersedia, dan tidak ada tumbuh-tumbuhan apa pun yang dapat hidup di atas permukaan bumi. Jika udara di atmosfer telah kurang padat dari sekarang, dua puluh juta meteor yang setiap hari masuk dengan kecepatan sekitar tiga puluh mil per detik, akan runtuh di seluruh bumi. Membakar semua bahan bakar dan lubangi seluruh permukaan bumi. Panas dari dari bepergian meteor

Karena padat yang cocok dengan apa yang umat manusia lindungi terhadap hujan berapi dari puing-puing angkasa ini. Kepadatan ini juga tepat agar sinar matahari dapat mencapai bumi dalam ukuran yang sangat luas yang akan meningkatkan pertumbuhan tanaman, menghancurkan bakteri berbahaya, dan menyediakan vitamin yang dapat diserap langsung dari sinar matahari melalui kulit, atau secara tidak langsung dari bahan makanan melalui sistem pencernaan. Betapa menakjubkan untuk memiliki semua manfaat ini sesuai dengan persyaratan kita. Mengambil oksigen, misalnya. Itu adalah sumber kehidupan dan tidak dapat diperoleh dari sumber lain mana pun selain dari atmosfer. Tapi jika itu terbentuk 50\% dari atmosfer atau lebih, bukannya $21 \%$ sekarang, mudah meledak dari semua materi di permukaan bumi akan begitu tinggi bahwa bahkan jika hanya satu pohon terbakar, seluruh hutan akan sekaligus meledak. Demikian pula, memiliki proporsi oksigen di atmosfer serendah $10 \%$. Kehidupan mungkin telah disesuaikan dengan keadaan ini selama berabad-abad, tetapi kecil kemungkinannya peradaban manusia akan mengambil bentuknya yang sekarang. Dan, jika semua oksigen gratis itu tidak hanya sebagian saja, telah diserap oleh materi yang ada di permukaan bumi, tidak akan ada kehidupan binatang yang mungkin sama sekali. Bersama dengan oksigen, hidrogen, karbon dioksida, 
dan gas karbon dalam bentuknya bebas serta dalam bentuk senyawa yang berbeda adalah unsur-unsur kehidupan yang paling penting: bahkan fondasinya, yaitu kehidupan kita.

Dalam pandangan modern ini, argumen yang paling sering dikutip adalah argumen kosmologis. Dan sainspun mulai pula menggeser Tuhan dalam wilayah ini, bukan dengan menyebutkan kalau alam ini pada dasarnya tidak teratur (berarti bunuh diri sains itu sendiri), tetapi dengan cara yang lebih elegan, denganmemin ta bantuan ranah ilmu yang lebih tinggi, matematika. Tabel berikut menunjukkan bagaimana konsep Tuhan dan sains saling berinteraksi membentuk sebuah evolusi konsep Tuhan dari masa ke masa.

\section{Kesimpulan}

Konsep Tuhan tidak dapat bersesuaian dengan sains dan hal ini telah cukup lama disebut-sebut dalam berbagai literatur. Penemuan sains terus menggeser posisi Tuhan sehingga Tuhan hanya dapat dipakai mengisi celah-celah kecil dalam pengetahuan (God of the Gap) dan pada gilirannya, Tuhan terhapus sedikit demi sedikit seiring terisinya celah tersebut oleh penemuan baru. Gagasan Tuhan yang lebih modern berpegang pada keteraturan alam itu sendiri. la tidak lagi digunakan sebagai penjelasan hal-hal istimewa di alam atau ketidakteraturan tampak di alam (mukjizat adalah bukti adanya Tuhan), tetapi dipakai untuk menjelaskan keteraturan itu sendiri. Hal ini sedikit aneh jika dilihat bagaimana ide Tuhan dipindah-pindahkan dari satu kotak ke kotak lainnya. Agama modern dan bahkan aliran baru ketuhanan yang tidak menyebut dirinya agama (deisme, panteisme) menyatakan keteraturan alam sebagai bukti adanya Tuhan. Dalam bentuk geseran ini, Tuhan didamaikan dengan sains. Terisinya celah-celah hanya memperkuat bukti adanya Tuhan, bukannya menyingkirkannya. 


\section{Evaluasi}

1. Baca teks ini dengan seksama, kemudian lakukan paraphrase (encoding) di setiap sub babnya!

2. Buat sebuah komentar menggunakan Thesis annotation, The probe annotation, Personal view annotation, dan Inventive annotation terhadap teks di atas untuk mengomentari setiap sub-babnya!

3. Buat kelompok diskusi setiap kelompok terdiri dari 5 orang mendiskusikan masalah-masalah berikut dan tuliskan hasil diskusinya:

a. Apa itu Sains

b. Eksistensi Tuhan Perspektif Saintis

\section{Referensi}

Bucaille, Maurice. The Bible, The Qur'an and Science. Edited by

Alastair D. Pannel and Maurice Bucaille. Lahore: Kazi

Publications, n.d.

Khan, Wahidu d-Din. Al-Islam Yatahadda. Edited by Zafarul Islam Khan. 4th ed. New Delhi: Goodword Books, 2005.

Boyer, Pascal. Religion Explained: The Evolutionary Origins of Religious Thought. New York: Basic Books, 2001.

Brown, Delwin, Sheila Greeve Davaney, and Kathryn Tanner (eds.). Converging on Culture: Theologians in Dialogue with Cultural Analysis and Criticism. (Reflection and Theory in the Study of Religion) American Academy of Religion Book, 2001. ISBN 9780195144673. 


\section{Teks VI}

\section{MONOTEISME DAN POLITEISME}

\section{A. PENDAHULUAN}

Manusia pada dasarnya memiliki bentuk kepercayaan kepada sesatu yang ghaib tau memiliki kekuatan diluar diri mereka yang dapat menentukan dan mempengaruhi kehidupan manusia. Hal tersebut, dapat dijumpai pada semua level kehidupan manusia, mulai dari apa yang disebut zaman primitif atau zaman purba hingga zaman modern yang sekarang ini. Pada zaman primitif, manusia memiliki kepercayaan terhadap Tuhan dengan cara mereka sendiri dan memberi sesembahan, sesajen, dan kurban untuk dipersembahkan. Pada zaman yang lain, mereka juga mempercayai Tuhan atau dewadewa dengan cara yang berbeda-beda. Pada tingkat atau suku tertentu persembahan kurban dilakukan dengan menggunakan manusia sebagai medianya untuk menaklukkan dewa tertentu bertujuan agar pada dewa atau dewi memberi kebaikan bagi mereka. Demikian kepercayan manusia terhadap Tuhan terus mengalami berevolusi. Salah satu teori dalam Antropologi agama menyebutkan bahwa evolusi kepercayaan manusia kepada Tuhan dimulai dari monoteisme, animisme, dinamisme, politeisme dan kembali ke monoteisme lagi. Kepercayaan manusia terhadap Tuhan disebut sebagai keadaan yang alami atau umum meskipun dalam kehidupan level mereka berbeda-beda. Ekspresi dalam penyembahan terhadap Tuhan saja yang membedakan mereka diantara level-level itu sebagaimana ditemukan dalam riset. Dalam hal ini penulis akan membahas mengenai Monoteisme yaitu faham yang mempercayai bahwa Tuhan itu tunggal dan lawan dari Monoteisme yaitu Politeisme merupakan suatu kepercayaan kepada banyak Tuhan atau dewa-dewa.

\section{B. MONOTEISME DAN POLITEISME}


Ketika literatur tulisan paku mulai menyingkap pesannya, ahli tulisan paku dan hieroglif Mesir segera mendapati diri mereka berhadapan dengan dahsyatnya jumlah dewa dan dewi, dan setan dan kekuatan spiritual lain yang lebih rendah, yang tampaknya selalu saling berperang dan kebanyakan amat destruktif. Namun saat lembaran-lembaran yang lebih tua digali dan jelaskan, dan memiliki keterampilan dalam menguraikan atau membedahnya meningkat, gambaran pertama dalam Politeisme kasar sedikit demi sedikit diganti oleh yang hampir mendekati hirarki seperti hal nya makhluk halus yang tersusun dengan satu satu Entitas Tertinggi diatas mereka semua atau Yang Maha Kuasa menjadi semacam pengadilan. Salah seorang ahli tulisan paku yang pertama kali mengakui signifikansi kecenderungan ini adalah Stephen Langdon dari Oxford, dan saat dia melaporkan kesimpulan ini dia melakukannya dengan kesadaran akan fakta bahwa dirinya tidak mungkin dipercaya. Menurutnya dia mungkin gagal meyakinkan dalm menyimpulkan bahwa dalam agama-agama sumeria maupun semit, monoteisme mendahului politeisme. Bukti dan alasan atas kesimpulam ini begitu bertentangan dengan pandangan yang lazim terkini. Dia percaya ini merupakan kesimpulan pengetahuan bukan kesimpulan prakonsepsi nekat.

Karena Langdon berpandangan bahwa bangsa sumeria merepresentasikan peradaban sejarah tertua dia menambahkan menurut pendapatnya sejarah peradaban tertua manusia adalah kemerosotan pesat dari monoteisme menuju politeisme ekstrim dan keyakinan pada roh jahat, ini adalah sejarah kejatuhan manusia. Lima tahun kemudian dalam artikelnya yang muncul dalam The Scotsman dia menulis, Sejarah agama Sumeria merupakan pengaruh budaya paling kuat di dunia kuno, bisa ditelusuri lewat Prasasti Fotografis hingga konsep keagamaan terawal manusia. Bukti-bukti lain yang tak salah lagi menunjuk pada sebuah monoteisme awal. Prasasti dan peninggalan sastra bangsa-bangsa semit tertua juga mengindikasikan 
pada monoteisme primitif dan asal-usul dari patung agama hebrew dan agama-agama Semit lainnya kini sama sekali tak dapat dipercaya.

Menurut sepengetahuannya hanya satu orang yang serius menentang kesimpulan London sejak saat itu. Dia adalah profesor T.J. Meek. Ragumen London didasarkan pada kondisi berikut :

Agama Sumeria dalam perkembangan terakhirnya sebelum bangsa lenyap sebagai sebuah entitas dan ditelan oleh Bangsa Babilonia yang muncul tampaknya memiliki sekitar 5000 dewa. Prasasti dari sekitar tahun 3000 SM atau mungkin lebih awal yang menunjukkan 750 dewa saja. Kemudian, 300 lembar asal jamdet Nasr Tahun 1928 ketika Langdon memoerkenalkan tulisan-tulisan ini, hanya memuat tiga dewa saja yaitu : Dewa Langit Enlil, Dewa Bumi Enki, dan terakhir Dewa Matahari Barbar. 575 lembaran berasal dari Uruk yang diterjemahkan pada Tahun 1936, yang dikatakan Langdon berasal dari 4000 SM tapi yang dipercaya saat ini lebih tepatnya berasal dari tahun 3500 SM, dimana hanya memuat dua Dewa saja yakni : Dewa Langit disebut An dan Ibu Dewi Innina. Kritik Meek terhadap pendapat Langdon adalah bahwa jumlah Dewa yang dia sebutkan untuk lembaran Jamdet Nasr itu adalah keliru. Dalam teksnya Nasr memiliki enam dewa, bukan hanya 3 dewa. Atas keterangan diatas Meek merasa diirinya dapat menuduh London membuat tidak akuratan besar dan membuat ruhtunya kekuatan argumennya. Tapi pada waktu yang sama dia mengakui bahwa kurang lebih dari enak dewa ini sifatnya meragukan. Lebih jauh, kita tidak bisa selalu yakin terhadap sebuah nama yang muncul dianggap sebagai seseorang yang menjadi sasaran do'a yaitu dewa. Berdoa'a pada santo bahkan juga sudah dikenal pada zaman modern! Bagaimanapun juga saat pandangan progresif sejarah membawa kita dari dua dewa menjadi entah tiga atau enam dewa dalam 500 tahun kemudian menjadi 750 dewa, lalu 1000 tahun kemudian sampai 
menjadi 5000 dewa sebelum gambaran menjadi kabur. Argumen yang menentang interpretasi Langdon berlandaskan kekeliruan penghitungan proporsi sekecil itu tentu saja tak berbobot sama sekali. Sungguh-sungguh itu tidak menentang pada argumen dasarnya.

Bagaimanapun juga, peralihan di Tell Asmar dari periode milenium ketiga SM telah membenarkan terhadap semua temuannya. Oleh karena itu, Henry Frankfor menulis dalam laporan resminya. Menurutnya, Selain hasil yang lebih nyata, penggalian telah membuktikan sebuah fakta baru yang akan harus dipertimbangkan oleh peneliti agama-agama Babilonia. dia telah memperoleh, material keagamaan yang utuh dalam suasana sosialnya.

Dia memiliki banyak sekali bukti koheren, diperoleh dalam jumlah yang sama dari sebuah kuil dan dari rumah-rumah yang dihuni oleh orang-orang yang melakukan penyembahan di kuil tersebut. Jadi, dapat ditarik kesimpulan, yang tak dimungkinkan oleh temuan sendiri.

Contohnya : kami menemukan bahwa (cylinder seal), yang biasanya terkait dengan beragam dewa, semuanya bisa dipasangkan menjadi gambaran yang konsisten di mana satu Tuhan yang disembah di kuil merupakan figur yang sentral. Tampaknya pada periode awal ini berbagai aspek-Nya tidak dianggap sebagai dewadewa yang terpisah di kuil Sumeria-Akkadia.

Disini ada satu pin yang penting : yakni, kemungkinan bahwa politeisme tidak pernah nampak lewat evolusi polidemonisme, tapi karena ada atribut-atribut Tuhan yang Maha Esa ditekankan secara berlainan oleh orang yang berlainan juga sampai beberapa tahun kemudian mereka jadi lupa bahwa mereka sedang membicarakan 
sosok yang sama. Sehingga atribut dari Dewa Tunggal menjadi pluralitas dewa-dewa. Bahkan masing-masing orang menekankan aspek yang berlainan terhadap sifat Tuhan tapi juga dengan seluruh keluarga dan suku yang nampaknya telah mengembangkan pandangan tertentu bersama apa yang penting dalam hidup dan apa yang tidak, oleh karenanya yang tak wajar, mengatributkan pada dewa mereka dan menekankan karakteristik-karakteristik istimewa itu yang bagi mereka penting sekali artinya.

Jauh sebelum Langdon membuat sebuah penerjemah, Friedrich Delitzsch membuat proposal yang sedikit mirip menyangkut pada kecenderungan yang berkelanjutan pada pelipatgandaan dewadewa. Dia merujuk kepada lembaran yang dilaporkan oleh T.G. Pinches yang meskipun terlestarikan secara kurang lengkap, tetap memberitahukan kepada kita bahwa bagaimanapun juga, dewa tertinggi di kuil Babilonia ditunjuk sebagai satu-satunya dewa Marduk. Dewa Marduk dinyatakan dengan nama "Ninib" (sebagai "Pemilik Kekuatan"), "Nergal" atau "Zamama" (sebagai "Raja Pertempuran"), "Bel (sebagai "Pemilik Kerajaan"), "Nebo" (sebagai "Raja Nabi"), "Sin" (sebagai "Penerang Malam"), "Shamash" (sebagai "Raja segala sesuatu Yang Bersifat Adil"), "Addu" (sebagai "Tuhan Hujan"). Nama-nama yang sebetulnya merupakan cara berlainan untuk melukiskan atribut, kekuatan, atau tugasnya.

Sejarah yang sama dapat ditelusuri di Mesir. Renouf dalam Hibbert Lectures-nya selama tahun 1879 mengutip dari M. de Rouge yang mengatakan bahwa sejak atau sebelum adanya permulaan periode sejarah, agama monoteisme murni dari Mesir melewati fase Sabeisme. Yaitu, matahari bukan dianggap sebagai simbol kehidupan, tapi diambil sebagai perwujudan Tuhan Sendiri. Rouge mengamati bahwa tak diragukan lagi bahwa bagian-bagian luhur agama Mesir bukanlah termasuk dari hasil belakangan sebuah proses 
perkembangan atau penyisihan bagian yang kotor. Bagian-bagian leluhur sudah jelas sekali berasal dari masa kuno dan tahap yang terakhir pada agama Mesir yang diketahui oleh para penulis Yunani dan Latin baik itu yang beragama kristen maupun yang menyembah berhala, jelas merupakan yang paling kotor dan yang paling korup."

Dalam pengamatan Renouf, M. de Rouge tak diragukan lagi tepat dalam penegasannya bahwa di beberapa tempat (pusat) pemujaan, satu dewa yang sama muncul berulang kali dengan nama dan simbol berbeda-beda. Dia menyimpulkan dari perjalanan sejarah bahwa karena politeisme terus-menerus bertambah [dalam jumlah dewa], maka doktrin monoteistis pasti telah mendahuluinya. Sungguh argumen yang amat masuk akal.

Lagi-lagi, sebagaimana di Sumeria dan Babilonia, bangsa Mesir juga seiring waktu berkembangbiak dan pecah menjadi faksifaksi dengan loyalitas kesukuan dan pilihan keagamaan kedaerahan dari konsep murni satu Tuhan yang pernah mereka miliki bersama di awal dan yang melibatkan beberapa pengetahuan. Ini menimbulkan kekacauan terhadap orang-orang, kemudian istilah-istilah yang deskriptif menjadi nama-nama dewa.

Rawlinson menulis bertahun-tahun berkaitan dengan ini. Bahwa dewa, sekali dibagi-bagi, tak ada batasan pada jumlah-Nya yang beragam jenis dan beragam tingkat; dan di Mesir segala sesuatu yang ambil bagian dalam esensi ilahi menjadi satu dewa. Meski sebetulnya bukan dewa, mereka membangkitkan perasaan hormat yang oleh orang bodoh tak bisa dibedakan dari pemujaan sungguhan.

Wajar jika dalam rangka melambangkan berbagai kekuatan Tuhan yang diajarkan bahwa penglihatan-Nya setajam elang atau kekuatannya sekuat banteng atau dia mulihat apa yang tak terlihat. Dengan seiring waktu lambang-lambang itu dislahphami oleh 
masyarakat umum sebagai dewa itu sendiri. Jadi terpenuhilah apa yang ditulis Paulus dalam Roma 1: 18-23, bahwa manusia beralih dari penyembahan Tuhan Sendiri menuju penyembahan makhlukmakhluk-Nya dan pada waktunya menjadi sia-sia dalam khayalan mereka, dan pemahaman mereka menjadi gelap.

Mungkin ada anggapan bahwa gambaran ini telah berubah menjadi radikal sejak zaman Renouf dan Hibbert Lectures-nya. Tidak demikian! Sir Flinders Petrie, dalam sebuah buku kecil luar biasa mengenai subjek agama Mesir, menulis bahwa Seandainya konsepsi satu tuhan hanyalah evolusi dari penyembahan roh, semestinya kita menemukan penyembahan banyak tuhan yang mendahului penyembahan satu Tuhan. Apa yang kita temukan merupakan sebaliknya, monoteisme adalah taraf pertama yang tertangkap dalam teologi.

Kemanapun kita menelusuri politeisme hingga taraf awal, kita akan menemukan bahwa itu adalah bentuk dari hasil kombinasi monoteisme. Di Mesir bahkan Osiris, Isis, dan Horus, yang begitu familiar sebagai bentuk tiga serangkai, awalnya didapati sebagai unit yang terpisah dalam kedudukan secara berlainan: Isis yaitu sebagai dewi perawan dan Horus berperan sebagai Tuhan yang eksis dengan sendirinya.

Pada tiap-tiap kota kelihatannya hanya memiliki satu Dewa, dan kemudian dewa-dewa lainnya ditambahkan. Sama dengan kotakota di Babilonia masing-masing memiliki dewa tertinggi, kombinasi serta transformasi mereka menjadi kelompok-kelompok saat kampung halaman mereka menyatu secara politik yang menunjukkan bagaiamana pada dasarnya bahwa mereka mulanya adalah dewadewa tersendiri. 
Begitu kita beranjak dari peradaban-peradaban kuno yang menuju Timur, sampai ke India. Di sini juga sudah mengalami pertambahan terhadap dewa secara terus menerus samapu berabadabad, sampai jumlah dewa mereka saat ini seperti bintang dilangit. Max Muller, lahir di Jerman Tahun 1823. Dia tidak percaya bahwa India kuno berkeyakinan monoteistis, tapi mereka juga tak percaya politeistis. Politeisme adalah tahap yang melibatkan proses degenarasi. (The Science of Language).

Jadi sekali lagi kita melihat bagaimana politeisme berkembang sesudah itu. mungkin tak salah kalau kita mengatakan tanpa ragu sedikitpun bahwa monoteisme tak pernah berevolusi dari politeisme dalam bagian sejarah purba dunia manapun, sebab kita punya bukti dokumenternya. Sebagaimana ini juga terjadi di China.

Saat zamannya banyak rekan yang tidak sependapat dengan interprestasi Muller atas bukti tersebut, Andrew Lang yaitu salah satunya. Edward McCrady, menulis tentang keyakinan keagamaan India, mengamati bahwa bahkan Rig Weda (Kitab 1, hal. 164) menunjukkan kepada kita bahwa di masa-masa awal, dewa-dewa mereka sebetulnya dipandang sebagai anekaragam perwujudan satu Entitas Ilahi.

Muller membagi pandangan Kristen tentang sejarah spiritual manusia. Dia mengakui, bahwa Terdapat monoteisme yang mendahului politeisme yaitu Weda dan bahkan dalam pemanggilan tak terkira banyaknya dewa, ingatan tentang Tuhan, yang maha esa dan maha kuasa, menerobos kabut fraseologi musyrik layaknya langit biru yang tersembunyi oleh awan yang melintas."

Saat sampai pada China, situasi yang ada lebih kacau lagi, sebab bangsa China sepertinya cina memiliki rasa enggan dan aneh terhadap penyembahan kepada dewa-dewa personal. Namun 
beberapa penulis lama yakin bahwa mereka dapat melihat ada bukti keyakinan kepada monoteisme yang dahulunya murni. Hampir tak terlihat akibat dari praktek ekstrim yang dilakukan bangsa China.

Williams menguraikan dalam bukunya berjudul Book of History dalam kalimat pembuka yang menyatakan bahwa penguasa, Shun, dalam kenaikan tahta pada tahun 2255 SM "mempersembahkan bentuk pengorbanan adat kepada Tuhan". Sumber mereka tidak begitu dipertanyakan sehingga tidak ada kalimat pengantarnya. Kemudian Williams melanjutkan bahwa:

Pada periode China, Tuhan Penguasa Tertinggi adalah Maha Esa yang tidak bisa dibagi, tidak berubah, kekal, tidak ada satupun yang setara dengan-Nya, berkuasa mutlak dan sendirian atas segala sesuatu di kayangan atas dan di bumi bawah. Dia mampu berbuat apa yang Dia kehendaki dan tidak ada kekuatan yang mampu menghalangi bahkan menandingi-Nya, dan kehendak-Nya selalu benar. Tapi tidak jarang Dia juga membiarkan orang jahat tumbuh subur dan dalam buku Odes kita sering mendengar adanya suara arwah yang mengeluh yang memberi kesempatan pada kita yaitu Job."

Kemudian Williams mencatat dalam bukunya Book of History ataupun Odes bahwa tidak ada penyebutan kepadaa berhala yang dapat ditelusuri. Tidaka ada lambang khusus yang pernah dibuat di China untuk apapun yang ada di kayang atas maupun bumi untuk bisa melambangkan Tuhan. Dan Dia boleh disembah saat kapanpun dan dimanapun, sebab Dia selalu ada bahkan hadir dimana-mana

Seiring waktu, keyakinan murni di China mulai memudar sebagaimana diungkap oleh dokumen serupa berikutnya bahwa doadoa kini dipanjatkan terlebih dahulu melalui leluhur kepada Tuhan yang tidak dimohoni langsung, dan kemudian seiring waktu 
dipanjatkan kepada leluhur saja. Kemudian, permohonan kepada Tuhan secara personal digantikan permohonan kepada kayangan, dan juga kepada bumi.

Berdasarkan semua hal yang telah ketahuan dari riwayat tertulis peradaban kuno, gambaran sejarah spiritual manusia, sepanjang menyangkut rumusan keyakinannya, kita cukup menyimpulkan bahwa manusia memulai dengan keyakinan murni terhadap Tuhan keadilan dan kepengasihan, yang maha ada, maha kuasa, dan maha tahu, yang bisa disembah tanpa memerlukan gambar-gambar atau perlengkapan lain semacam itu. Konsep ini, nyatanya, terlampau tinggi untuk bertahan di kalangan orang biasa yang pengetahuannya tidak diperkuat secara mukjizat atau ditambah secara terus-menerus melalui wahyu. Politeisme kasar paganisme di dunia klasik Roma dan Yunani bisa diterangkan bukan sebagai [kondisi] manusia yang berusaha memurnikan keyakinannya melainkan kehilangan pesat atas keyakinan yang pernah dimilikinya. Taraf kesamaan kemerosotan keyakinan dunia klasik Roma dan Yunani dengan Timur Tengah ini dibuktikan secara luas dalam studi mahsyur Hislop, The Two Babylons

Kita tak punya riwayat tertulis untuk membahas keyakinan awal bangsa primitif, tapi banyak studi rinci dan penuh perhatian mengenai keyakinan mereka telah dijalankan selama seratus tahun terakhir dan dikumpulkan khususnya oleh Wilhelm Schmidt. Buktibukti, menurut kesimpulan, memperkenankan kita untuk mengatakan dengan yakin bahwa perjalanan sejarah keagamaan mereka persis sama dengan peradaban purba yang lebih tinggi dengan perbedaan berikut: di negeri-negeri beradab tersebut, keyakinan murni terkorupsi oleh argumentasi cacat akibat kebobrokan sifat manusia, sedangkan di kalangan bangsa primitif, 
keyakinan murni terkorupsi akibat kebodohan dan ketakhayulan, dan diperkuat lagi-lagi oleh kebobrokan sifat manusia.

Seandainya kita mengikuti prinsip Lyell dalam menafsirkan masa lampau cukup dari segi hal-hal yang terjadi selama masa sejarah, maka kita tak punya hak apapun untuk membuat asumsi bahwa manusia berawal dengan meraba-raba di kegelapan dan baru sekarang mulai menghampiri Cahaya. Bukti-bukti menunjukkan bahwa dia memulai dengan Cahaya sejati dan kini pemahamannya semakin gelap. Bukti mengenai prinsip ini di kalangan bangsa primitif ditemukan pada setiap pelosok dunia di mana bangsa semacam itu kini eksis atau pernah eksis pada masa-masa belakangan. Dan kepercayaan atas paradoksnya, semakin primitif mereka, semakin sederhana dan semakin murni keyakinan mereka.

Sudah tidak diragukan lagi, karya yang paling informatif mengenai monoteisme bangsa primitif adalah karangan dari Wilhelm Schmidt, yang, meski mulanya terdiri dari banyak volume di Jerman, di terbitkan sebagai satu volume terjemahan dengan versi ringkas pada bahasa Inggris pada tahun 1930. Ini adalah studi yang sangat hebat, anda tidak akan menemukan kekakuan dan sangat informatif. Pertama - pertama Schmid melakukan pengamatan mengenai pemikiran tentang subjek dari asal-usul agama saat berkembang pada abad yang lalu. Schmidt mengatakan bahwa Herbert Spencer sebagian besar bertanggung jawab atas adanya interpretasi pertama pada evolusi agama, mengingat dia mendahului darwin 7 tahun, sebagaimana yang telah ditunjukkan pada artikelnya yaitu The Development Hypothesis yang terkuak dalam the leader pada tanggal 20 Maret 1852. Perlu dicatat, bahwa sepintas lalu Tennyson menulis In Memoriam, dengan kekeliruan dalam deskripsinya tentang alam sebagai "merah di gigi dan cakar". 10 tahun sebelum artikel darwin muncul, schmidt mengamati bahwa spencer tidak pernah berusaha 
menggunakan metode sejarah dalam tesisnya. Atas dasar bukti tersebut, maka jelaslah bahwa spencer sudah salah yang berpandangan jika bangsa primitif memulai dengan menyembah leluhur. Begitu peradaban berkembang, leluhur tentu saja disusun menjadi hirarki kemudian akan menghasilkan pangkat dan pangkat tertinggi menjadi dewa.

Yang bisa schmidt lakukan untuk membuktikannya yaitu bahwa jika kebudayaan-kebudayaan primitif berkelompok atas dasar tingkat kebudayaan mereka kemudian ditempatkan ke dalam urutan menaik, maka akan ditemukan bahwa kelompok terendah memiliki konsep Tuhan yang paling murni dan kelompok berkembang akan menjadi pengumpul atau penanam makanan, penggembala yang memelihara sekawanan binatang, menjadi penanam makanan dalam penggunaan tanah yang ditempati yang akan naik derajat menjadi komunitas semi-urban. Pertama kita menemukan keyakinan yang sederhana kepada entitas Tertinggi yang tidak mempunyai istri maupun keluarga. Lalu, dibawahNya atau ciptaanNya adalah pasangan atau suku pertama yang diturunkan, menurut schmidt kita menemukan bentuk keyakinan seperti itu dari kalangan pigmi Afrika Tengah penghuni Australia Tenggara, penghuni utara California tengah, Algonkin primitif dan hingga ke taraf tertentu. Menurut schmidt pada tatanan kebudayaan primitif berikutnya kondisi berubah sama sekali. Bukan dari pasangan pertama yang dapat penyembahan namun sejumlah leluhur mati besar atau kecil lainnya. Pada kompleksitas budaya penyembahan leluhur dan orang mati lainnya menggantikan penyembahan terhadap entitas Tertinggi sepenuhnya. Dewa-dewa yang diakibatkan menghasilkan berbagai macam gambar. Perkembangan pemahaman spiritual manusia adalah bentuk kemundura, terkadang langkah pertamanya adalah peralihan dari pencipta entitas Tertinggi kemudian muncul sebagai perantara antara Tuhan dan manusia, tapi karena lebih mudah untuk 
dibayangkan maka dia segera menggantikan Tuhan sama sekali. "kepalsuan teori spencer dapat dilihat dari fakta bahwa penyembahan leluhur berkembang dengan sangat lemah dalam kebudayaan-kebudayaan tertentu sedangkan agama monoteistis sudah jelas ditemuka disana dan perkembangan tertinggi penyembahan leluhur tidak timbul sampai masa belakangan".

Schmidt lalu membahas mengenai pandangan alternatif kedua mengenai asal-usul agama, konsep animistis yang diajukan oleh E.B Tylo. Dia mengasumsikan bahwa manusia primitif menggunakan eksistensinya sendiri sebagai ukuran semua eksistensi lain yang menganggap segala sesuatu mulai dari hewan dan tumbuhan tapi akhirnya benda mati sekalipun yang terdiri dari raga dan jiwa seperti dirinya. Diasumsikan bahwa manusia primitf segera akan memulai menilai bahwa dirinya memiliki jiwa yaitu suatu jenis realitas spiritual internal. Dia memakai kehidupan jiwa yang mirip dengan miliknya, yang tidak bisa dilihat tapi ada, pada semua kekuatan alam. Dari konsep animistis tadi dia menuju pandangan bahwa dunia ini bersifat personal, sehingga muncullah polidemonisme. Sama halnya dengan dunia setan sampai tiba saatnya banyak setan yang diangkat menjadi dewa. Tahap terakhir adalah pengakuan atas satu entitas yang menjadi pemimpin yakni Tuhan, hanya kepadaNya setan maupun dewa-dewa lebih rendah dan tunduk. Setelah rasionalisasi ini diduga telah melahirkan keyakinan monoteisme. Tylor tetap yakin terhdap pendapatnya bahwa semua itu terlalu dimuliakan, terlampau tinggi untuk membutuhkan penyembahan dari manusia. Jadi keyakinan monoteisme yang dihasilkan dari adanya proses rasionalisasi yang lebih lanjut kemudian keyakinan itu tergeser oleh urgensi hidup sehingga menjadi tidak relevan. Teori Tylor seperti teori spencer yang memuat semua isyarat sumbernya, terutama pada asumsi apriorinya mengenai perkembangan manusia yang naik dalam satu garis dan 
tidak adanya bukti apapun bahwa tahap-tahap tersebut memiliki hubungan historis apapun satu dengan yang lain.

Schmidt mempertimbangkan satu pandangan lebih lanjut yaitu pandangan Max Muller yang telah mengembangkan teori kompleks yang berargumen bahwa upaya untuk merasionalisasikan kekuatan-kekuatan yang ada di alam yang bekerja didunia seperti matahari, bulan, bumi, guntur, air, api yang akan membawa pada cerita-cerita yang berusaha menjelaskannya ke dalam bentuk mitos alam. Istilah-istilah penting yang ada dalam mitos ini, misalnya api atau langit jadi orang kurang berakal akan menganggap itu sebagai nama-nama dewa yang akan mengahsilkan kuil purbakala klasik. Namun schmidt menguraikan, terlepas dari kemasyhuran dan pengetahuan hebat yang dimilikinya, Max Muller hidup sangat lama, cukup lama untuk melihat ide-idenya yang perlahan ditinggalkan sama sekali.

Schmidt menyimpulkan apa yang dia ketahui mengenai asala mula ide Entitas Tertinggi di kebudayaan-kebudayaan primitf. Dia berkata bahwa manusia mempunyai kebutuhan sosial moral dan emosional. Pertama, kebutuhan sosial dipenuhi oleh keyakinank awal terhadap Entitas Tertinggi yang juga merupakan pemimpin manusia atau Tuhan. Yang kedua, kebutuhan moral mendapat sandaran dalam keyakinan terhadap Entitas Tertinggi yang menjadi hakim kebaikan dan keburukan sehingga terbebas dari noda moral. Kelompok kebutuhan yang terakhir adalah emosional dipenuhi oleh keyakinan terhadap Entitas Tertinggi yang mempunyai sifat pemurah tidak ada yang keluar dari-Nya selain kebaikan. Manusia memiliki kebutuhan yang lain sehingga dia mencari sebab dan dipenuhi oleh konsep Entitas Tertinggi yang menciptakan dunia dan yang memerintahnya sedemikian rupa sehingga menjadi masuk akal. Manusia juga butuh adanya pelindung dan menemukannya pada 
Entitas yang Maha Kuasa. Jadi dalam semua atribut ini, sosok yang dimuliakan menjadi pelengkap manusia primitif dengan kemampuan dan kekuatan untuk hidup dan mencintai, untuk percaya dan bekerja, dan untuk mengorbankan tujuan yang tak bernilai demi mendapat tujuan yang bernilai. Schmidt mengatakan " jadi dapat kita temukan diantara seluruh rangkaian ras primitif terdapat sebuah agama yang mencolok yaitu yang bercabang banyak dan sepenuhnya efektif".

Kembali ke bangsa paling primitif yakni pigmi Afrika atau penghuni Australia tengah atau Indian California tengah-semuanya memiliki satu dewa yaitu Dewa Langit Tertinggi yang mereka sembah dengan memberi persembahan berupa darah mereka dan buah pertama mereka yang diperoleh dari perburuan atau dari tanah. Semua bangsa memiliki doa-doa dan upacara untuk menyembah Tuhan Tertinggi Pencipta yang sebelumnya tak ada satupun yang eksis.

Banyak penulis subjek yang memilih suku-suku primitf karena mereka semua adalah bangsa yang terisolasi dalam beberapa hal baik karena tempat tinggal dipulau yang terpisah, dihutan tak ramah, diiklim tak ramah ataupun karena permusuhan secara terangterangan mereka terhadap manusia berkulit putih.

Setelah Andrew Lang menguraikan bahwa Aborigin Australia mempunyai kebudayaan yang paling sederhana diantara bangsabangsa kita kenal, mereka memiliki konsepsi keagamaan yang mulia sebagai hasil dari pengaruh Eropa. Namun, waktu penulisan, dia merasa penjelasan ini sungguh tidak dibenarkan, Tuhan adalah Yang Maha Tahu segala sesuatu yang ada dilangit maupun dibumi., mengganjar perilaku baik manusia dan lewat pelajaran-Nya, dapat melembutkan hati. Begitulah keyakinan mereka. 
Penulis yang berbicara tentang bangsa Andaman yang menyatakan bahwa Tuhan mereka tidak bisa dilihat, kekal, pencipta segala sesuatu kecuali kekuatan jahat, mengetahui yang ada di pikiran maupun hati, murka terhadap segala jenis kepalsuan, mengasihani mereka yang kesusahan dan terkadang memberi pertolongan secara personal. Dia adalah hakim jiwa dan pada suatu waktu dimasa depan akan memimpin pengadilan besar. Informasi yang disampaikan kepada Lang berasal dari para anggota sepuh yang tidak tersentuh dengan ras-ras yang lain pada waktu itu.

Samuel Zwemer berbicara soal karakter monolitis Entitas Tertinggi Pigmi Afrika, penghuni Tierra del Fuegian, Indian Amerika Utara, Bushmen primitif serta banyak bangsa-bangsa kebudayaan arktik yang menurutnya bahwa semua bangsa primitif memiliki pengetahuan tentang Dewa Tertinggi, tapi juga Dewa Tertinggi yang mereka sembah adalah sosok yang beratribut sama dimana-mana. Pendeta Titcombe membicarakan tentang suku Zulu penyuka perang. Mengutip dari mantan uskup natal yang bersentuhan langsung dengan mereka saat masih utuh dengan budaya yang mengatakan bahwa mereka tak punya berhala melainkan memiliki Entitas Tertinggi dikenal sebagai Great-Great One. Terlepas dari reputasi mereka sebagai suku tanpa adanya konsep Tuhan, suku Zulu sering menyebut-Nya dan atas dasar kemauan mereka sendiri dianggap sebagai pencipta segala sesuatu dan seluruh manusia.

Berbicara mengenai Indian Amerika yang ditulis oleh Paul Radin mengatakan " kebanyakan dari kita dibesarkan dari ajaran etnologi ortodoks dan ini sebagian besar merupaka upaya bersemangat dan tanpa kritik untuk menerapkan Teori Evolusi Darwin pada fakta-fakta pengalaman sosialnya. Banyak yang masih bertahan dalam usaha keras tersebut. Namun tidak ada kemajuan yang dicapai samapi cendekiawan membuang gagasan aneh bahwa 
segala sesuatu memiliki sejarah evolusi". Beberapa tahun kemudian, berbicara tentang pandangan yang dikemukakan Lang bahwa politeisme tidak mendahului dan melahirkan monoteisme. "pemahaman intuitifnya diperkuat secara berlimpah".

\section{KESIMPULAN}

Monoteisme adalah faham yang meyakini Tuhan itu tunggal dan personal, sempurna, tak berubah, pencipta seluruh alam semesta dan mewajibkan kebaktian terhadap satu Entitas tertinggi. Sedangkan Politeisme adalah kepercayaan kepada dewa-dewa. Tujuan beragama dalam politeisme bukan hanya sekedar memberikan sesajen atau persembahan kepada dewa-dewa tapi juga menyembah dan berdo'a kepada mereka untuk menjauhkan amarahnya dari masyarakat yang bersangkutan. Mustahil untuk mempertahankan terhadap evolusi sepihak dalam pemikiran dan praktek keagamaan dengan gaya yang ditunjukkan oleh klasifikasi rasionalistis Tylor dan Frazer sepanjang dengan adanya garis "Hukum Tiga Tahap" yang dikemukakan oleh comte. Meskipun spekulasi Euhemeran mengenai ide tentang Tuhan yang timbul dalam penyembahan leluhur yang munculkan kembali oleh Herbert Spencer ataupun evolusi monoteisme dari politeisme dan animisme ala frazer sebagai hasil dari keunikan ide-ide, tidak bisa direkonsiliasikan dengan sosok bayangan yaitu Entitas Tertinggi, kesukuan yang kini diketahui merupakan fitur berulang dari konsepsi primitif tentang Dewa. Dari kebudayaan tinggi dan kebudayaan rendah muncul gambaran yang sama. Gambaran konsep luar biasa ini murni sifat Tuhan dan hubungan-Nya dengan manusia seiring waktu terkorupsi, disatu sisi lewat rasionalisasi yang dihasilkan yaitu dari penggantian wahyu dengan pemikiran manusia sendiri secara bertahap dan disisi lain lewat kepercayaan takhayul yang sudah berakar dari kebodohan dan lupa akan wahyu asli. 


\section{Evaluasi}

1. Baca teks ini dengan seksama, kemudian lakukan paraphrase (encoding) di setiap sub babnya!

2. Buat sebuah komentar menggunakan Thesis annotation, The probe annotation, Personal view annotation, dan Inventive annotation terhadap teks di atas untuk mengomentari setiap sub-babnya!

3. Buat kelompok diskusi setiap kelompok terdiri dari 5 orang mendiskusikan masalah-masalah berikut dan tuliskan hasil diskusinya:

a. Definisi Politeisme dan monoteisme

b. Evolusi Agama mana yang terlebih dulu muncul apakah Politeisme atau monoteisme

\section{Referensi}

Eliade, Mircea. "Monotheism." In Encyclopedia of Religion. New York: MacMillan Publishing, 1987. ISBN 978-0029094808

Frazer, James George. The Golden Bough: A Study in Magic and Religion. New abridgment from 2nd and 3rd eds. Oxford University Press, 1998. ISBN 0192835416 (originally published in 1900)

Greer, John Michael. A World Full of Gods: An Inquiry Into Polytheism. ADF Publishing, 2005. ISBN 0976568101

Hutton, Ronald. The Triumph of the Moon: A History of Modern

Pagan Witchcraft. Oxford: Oxford University Press, 2001. ISBN 0192854496

Kirsch, Jonathan. God Against the Gods: The History of the War Between Monotheism and Polytheism. Penguin, 2005. ISBN 0142196339

Kirsch, Jonathan. God Against the Gods: The History of the War Between Monotheism and Polytheism. Penguin, 2005. ISBN 0142196339 
Lindow, John. Handbook of Norse mythology. Santa Barbara, CA: ABC-CLIO, 2001. ISBN 1576072177

MacDonald, Nathan. "The Origin of 'Monotheism'." In Early Jewish and Christian Monotheism, edited by Loren T. Stuckenbruck and Wendy E. S. North. London: T \& T Clark International, 2004. ISBN 0567082938

Ochshorn, Judith. The Female Experience and the Nature of the Divine. Bloomington: Indiana University Press, 1981. ISBN 025331898X

Pagels, Elaine. Adam, Eve, and the Serpent. New York: Random House, 1988. ISBN 0679722327

Prager, Dennis. "Ethical Monotheism."Jewishvirtuallibrary. Retrieved April 29, 2006.

Rohi, Rajinder Kaur. Semitic and Sikh Monotheism: A Comparative Study. Patiala, India: Punjabi University Publication Bureau, 1999. ISBN 8173805504

Silberman, Neil A. et al. The Bible Unearthed. New York: Simon and Schuster, Reprint edition, 2002. ISBN 0684869136

Smith, Mark S. The Early History of God: Yahweh and Other Deities in Ancient Israel, Second ed. Grand Rapids, MI: William B. Eerdman's, 2002. ISBN 080283972X

Tylor, Edward B. Primitive Culture: Researches into the Development of Mythology, Philosophy, Religion, Language, Art and Custom. 2 vols. (original 1871) reprint ed. Kessinger Publishing, LLC, 2007. Vol. 1: ISBN 0548128219; and vol. 2: ISBN 0548128227 


\section{TEKS VII}

\section{HUKUM KAUSALITAS PERSPEKTIF AL-GHAZALI}

Kausalitas adalah prinsip sebab akibat..yang ilmu dan pengetahuannya secara otomatis bisa diketahui tanpa membutuhkan pengetahuan dan perantara ilmu yang lain. Kausalitas merupakan hubungan yang dibangun antara suatu kejadian (sebab) dan kejadian kedua (akibat), pemahaman terhadap kejadian kedua sebagai konsekuensi dari kejadian yang pertama. Sedangkan para filosof meyakini hukum kausalitas (sebab-akibat) sebagai hukum yang mengatur alam semesta. Para filosof, menggunakan hukum kausalitas untuk membuktikan eksistensi Tuhan (pembuktian eksistensi Tuhan). Hukum kausalitas menjadi pondasi bagi teori-teori yang dikemukakan oleh para filosof maupun para pemikir lainnya. Hukum kausalitas telah dianggap sebagai kebenaran yang tidak terelakkan (dharuriy).

Dua tokoh besar dari kalangan Timur dan Barat bersepakat untuk menolak eksistensi Hukum Kausalitas. Dua tokoh tersebut adalah Al-Ghazali dan David..Hume. Imam Al-Ghazali...dalam bukunya yang berjudul Tahafut al-Falasifah, beliau menolak dua puluh pendapat para filosof Muslim terhadap berbagai persoalan yang diantara salah satunya mengenai hukum kausalitas. Dan David..Hume yang merupakan tokoh sentral aliran empirisme yang berkembang di Eropa. Kedua tokoh ini menganggap bahwa hukum kausalitas tidak lebih dari rangkaian peristiwa yang sering disaksikan yang dianggap sebagai hukum kausalitas benar-benar eksis.

Bagi Al-Ghazali dan David..Hume, kita tidak bisa memastikan bahwa kertas yang disentuh api selalu terbakar, meskipun yang terlihat nyata benar demikian. Api bukan penyebab terbakarnya 
kertas. Lalu, apakah yang menyebabkan kertas itu terbakar? AlGhazali menyatakan bahwa penyebab kertas yang terbakar adalah Allah, baik dalam bentuk intervensi ataupun melalui perantara malaikat. Sedangkan David..Hume menyatakan bahwa tidak ada yang menyebabkan kertas tersebut terbakar karena konsep sebab-akibat itu tidak ada.

Imam Al-Ghazali menafikan eksistensi hukum kausalitas dengan tujuan agar bisa menjelaskan terjadinya mukjizat yang banyak dilakukan oleh para nabi. Nabi Ibrahim yang tidak terbakar oleh api, dimengerti karena yang menyebabkan terbakar adalah Allah, bukanlah api. Tujuan Al-Ghazali..yang kedua adalah untuk satu pemikiran yang dapat disepakati oleh seluruh kaum muslimin, yakni bahwa Allah adalah Maha Kuasa. Karena tujuan ini, banyak sarjana islam modern melihat pemikiran imam Al-Ghazali..sebagai sisi yang negatif. Mereka berkesimpulan bahwa pemikiran Al-Ghazali akan melemahkan kegiatan intelektual umat muslim. Dengan alasan ini, para sarjana menuduh Al-Ghazali berpihak kepada teolog dan berfikiran dengan pola tradisionalis.

David..Hume menafikan hukum kausalitas atas dasar konsistensi terhadap empirisme.Emprisme merupakan sebuah pemahaman yang mengatakan bahwa satu-satunya instrument untuk memperoleh pengetahuan adalah pengamatan. Ketika kita mengamati kertas yang terbakar saat disentuh api, kita mendapat pengetahuan bahwa kertas terbakar dan kemudian berubah menjadi abu. Dalam pengamatan tersebut, tidak didapati bahwa kertas terbakar akibat..dari api, dan tidak didapati pula api yang menjadi sebab terbakarnya kertas tersebut. Kedua tokoh tersebut menafikan hukum kausalitas dengan motif yang berbeda, Al-Ghazali..dengan motif teologis sedangkan David..Hume dengan motif epistemologis. Dalam pemikira teologis, kausalitas tidak pernah dianggap sebagai 
bentuk murni dari gambaran fenomena. Sebuah sebab tidak bisa berarti sesuatu yang dapat menghasilkan eksistensi lain sebagaimana yang dimengerti filsafat.

Selain kesamaan pendapat antara Imam Al-Ghazali dan David..Hume mengenai hukum kausalitas, terjadi polemic antara AlGhazali dan Ibn..Rusyd mengenai hukum kausalitas. Cara pandang yang sacara teologis..Al-Ghazali..yang menilai para filosof terdahulu antara lain Al-Farabi, dan Ibnu Sina telah melakukan bid'ah karena telah meyakini hukum kausalitas. Dan mengenai penilaian Al-Ghazali tehadap dua filosof terdahulunya ini,Ibnu Rusyd melihat Imam AlGhazali telah keliru menilai pemikiran dua filosof tersebut.

Al-Ghazali telah menilai kafir bagi mereka yang meyakini tiga masalah: kadimnya alam, pengetahuan Tuhan tentang parsial (juz'i) dan kebangkitan jasmani. Beliau telah menyatakan bid'ah bagi orang yang mempercayai tujuh masalah lain, yang salah satunya adalah hukum kausalitas. Kritik imam Al-Ghazali kepada Al-Farabi dan Ibnu Sina, dalam penilaiannya sudah terlalu jauh mencampurkan ajaran agama dengan pandangan filsafat, yaitu filsafat...Yunani (Aristoteles). Dalam bukunya tahafutal-falasifah, Al-Ghazali menyatakan bahwa keterkaitan antara sesuatu yang diyakini sebagai akibat dari kebiasaan (al-'adah) tidaklah bersifat pasti (dharuriy). Tidak ada kepastian pada salah satunya, baik itu yang sebab maupun yang akibat. Yang disangkal oleh Imam..Al-Ghazali adalah anggapan bahwa sifat-sifat khusus padaalam berfungsi dengan sendirinya tanpa ada kaitan dengan Tuhan. Al-Ghazali memandang bahwa sifat khusus pada alam tidak dapat terlepas dari qudrahNya ,maka bagaimana mungkin jika benda mati bisa membakar sebuah benda yang berada di dekatnya, dengan kehendak api itu sendiri. Menurut beliau ini tidak mungkin terjadi. 
Contoh lain selain kertas yang terbakar oleh api adalah kapas. Bagi para filosof, pelaku (al-fa'il) pembakaran tersebut adalah api. Api menjadi pelaku karena wataknya dan bukan karena ikhtiarnya.

Hal ini yang disangkal oleh Al-Ghazali dengan dasar bahwa Tuhanlah yangmenciptakan hitam pada kapas, mengubah struktur bagiannya sampai bertransformasi ke dalam tumpukan nyala api atau debu, baik melalui perantara malaikat ataupun tanpa perantara. Api adalah benda mati yang tidak bisa mencipta perbuatan. Al-Ghazali dalam hal ini bermaksud mempertahankan hubungan alam yang imanen dan sisi lain Tuhan yang transenden. Dengan demikian, sifat Tuhan sebagai pencipta akan selalu tampak dan proses penciptaan terus berlanjut tanpa henti. Namun pada dasarnya, Imam AlGhazali...tidak mengingkari prinsip kausalitas secara total. Baliau tetap mengakui adanya keterkaitan antara sebab dan akibat pada benda-benda yang ada di alam ini. Karena ketetapan ini disebut sebagai sunnatullah. Akan tetapi, semua terjadi bukan secara kebetulan dan spontan menurut kehendak dari benda-benda itu sendiri sebagaimana pemikiran dari kaum materialis atau naturalis. Para...filosof selalu mengembalikan fenomena alam ini sebagai asal mula dari dan karena alam itu sendiri.

Yang disangkal Al-Ghazali..dalam hal kausalitas adalah "memastikan" terjadinya efek dari sifat-sifat khas pada segala sesuatu. Meskipun, kesimpulan dari proses pengamatan secara indrawiyang berasal dari kebiasaan (al-'adah). Dari kebiasaan dapat ditarik kesimpulan, namun hasilnya tidak pasti. Bagi Imam Al-Ghazali, segala sesuatu dihadapan Allah adalah "mungkin" dan semuanya masuk akal. Segala sesuatu bisa berubah di luar kebiasaan sesuai dengan kesiapan benda-benda itu dalam menerima sebab yang mengubahnya. 
Akan tetapi para filosof tidak sependapat dengan Al-Ghazali. Mereka menolak apa yang telah terjadi kepada nabi Ibrahi a.s. saat dibakar. Bagi mereka, Nabi Ibrahim tidaklah dibakar. Karena sifat pada api bersifat tetap dan permanen, jadi tidak mungkin api berubah menjadi dingin kecuali jika panas pada api dihilangkan. Dengan demikian, berarti telah mengubah sifat dan keadaan api. Atau bisa jadi, Tuhan telah mengubah jasad nabi Ibrahim menjadi batu atau sesuatu yang lain yang tidak terpengaruh oleh api. Hal ini tidak mungkin.

Akan tetapi, bagi Imam Al-Ghazali yang telah terjadi pada nabi Ibrahim mungkin saja terjadi. Nabi Ibrahim tidak terbakar oleh api karena Allah yang telah mengubah sifat api. Atau mungkin melalui malaikat, dengan cara mengurangi kadar panas pada api tersebut hingga api tidak berpengaruh pada nabi Ibrahim. Atau mungkin, dengan cara mengubah sifat nabi Ibrahim dengan cara memperbarui sifat yang terdapat pada jasadnya, sehingga tertolaklah efek dari api tersebut. Imam Al-Ghazali menyatakan bahwa para filosof..tidak mempercayai hal tersebut karena mereka tidak menyaksikannya.

Tidak hanya kertas dan kapas yang terbakar oleh api yang digunakan Al-Ghazali untuk mengkritik hukum kausalitas. Beliau juga membahas mengenai dihidupkannya orang yang sudah meninggal, berubahnya tongkat menjadi ular, dapat terjadi karena materi sesungguhnya dapat menerima berbagai macam perubahan. Tanah dan segala unsur bisa berubah menjadi tumbuhan. Kemudian setelah tumbuhan dimakan oleh manusia dan hewan berubah menjadi selsel darah. Darah berubah menjadi sperma. Sperma dimasukkan ke dalam Rahim, maka jadilah binatang-binatang. Lalu mengapa para filosof..menolak kekuasaan Allah untuk memutar suatu materi melalui fase ini, dalam waktu yang lebih pendek dari yang biasa terjadi. Hal ini menimbulkan sesuat yang disebut sebagai mukjizat 
bagi seorang nabi. Segala kemungkinan bisa saja terjadi, tetapi kemungkinan itu tidak terjadi begitu saja. Kekhususan pada diri nabi tidak menutup kemungkinannya secara akal. Oleh karena itu, mengapa harus didustakan ketika suatu berita dinukilkan secara mutawatir dan dibenarkan syara'.

Al-Ghazali...tidak membantah sanggahan para filosof...mengenai hukum kausalitas. Beliau mengakui bahwa bendabenda alami mempunyai keadaan atau sifat-sifat yangmenjadi pembeda satu dengan yang lainnya. Akan tetapi, semua itu dalam segi kemungkinan bukan kepastian, karena Allah yang menjadikannya dalam wujud yang demikian, dan Allah yang berkuasa untuk mengubah sifat-sifat benda tersebut jika la telah menghendaki.

Dalam maqashid al-falasifah, Al-Ghazali...menggunakan istilah illah dan ma'lul sebagai istilah kausalitas (sebab-akibat). Segala sesuatu yang mempunyai wujud pada dirinya sendiri yang bukan berasal dari wujud sesuatu yang lain adalah ma'lum. Sedangkan jika ma'lum tidak terwujud, kecuali dengan sesuatu yang lain, maka sesuatu itu disebut 'illat bagi ma'lum.

\section{Evaluasi}

1. Baca teks ini dengan seksama, kemudian lakukan paraphrase (encoding) di setiap sub babnya!

2. Buat sebuah komentar menggunakan Thesis annotation, The probe annotation, Personal view annotation, dan Inventive annotation terhadap teks di atas untuk mengomentari setiap sub-babnya!

3. Buat kelompok diskusi setiap kelompok terdiri dari 5 orang mendiskusikan masalah-masalah berikut dan tuliskan hasil diskusinya:

a. Pendapat Al-Ghazali tentang Hukum Kausalitas 
b. Kritikan Al-Ghazali terhadap kelompok Filosof

\section{Referensi}

Al-Ghazali, Abu Hamid. Ihya' Ulumuddin. 1st ed. Beirut: Dar Ibnu Hazm, 2005.

- - - Tahafut Al-Falasifah. Edited by Sulayman Dunya. 6th ed. Kairo: Daru I-Ma'arif, 1980.

Ibnu Sina, Abu 'Ali Al-Husain. Al-Risalah Al-'Arshiyyah Fi Tawhidihi Ta'Ala Wa Sifatuhu. 1st ed. Omman: Matabi' Dairah alMa'arif al-'Amaniyyah, 1934.

- - . An-Najah Fii I-Mantiq Wa I-Ilahiyyat. Edited by Majid Fakhry. Beirut: Daru I-Afaq Al-Jadidah, 1982. 


\section{TEKS VIII}

\section{ARGUMEN TENTANG TAUHID}

\section{A. PENDAHULUAN}

Dalam tauhid konsep atau tatanan kepercayaan tuhan dalam islam merupakan persoalan yang paling mendasar dalam mengenal identitas atau jati diri dan agamannya. Selain itu islam juga memandang berbagai perspektif dalam kehidupan dari segi ilmu pengetahuan, nilai - nilai, kehidupan bahkan tentang konsep dunia, dari pandangan tersebut dapat membantu bagaimana menentukan nilai benar atau salahnya suatu kepercayaan yang di anut setiap manusia, karena menyangkut akan keselamatan dunia serta akhiratnya.

Dalam islam konsep tentang tuhan dapat di sebut sebagai tauhid. Dari tauhid inilah merupakan visi dan misi para nabi serta rasul dalam berdakwah kepada seluruh umat manusia. Dalam islam menyepakati kalimat tauhid yaitu "Lailaha illa Allah". Dalam tauhid di bagi menjadi 3 dalam pengenalan terhadap Allah SWT, antara lain

- Tauhid Rububiyyah

- Tauhid Uluhiyyah

- Tauhid Asma' wa Al Sifat

Dari pembagian tauhid tersebut menjelaskan tentang mengesakan Allah dalam segala perbuatannya dan menyakini bahwa Allah yang menciptakan seluruh alam semesta beserta isinya, mengesakan Allah dengan menjalankan seluruh ibadah yang telah di perintahkan serta menjauhi larangannya, mengesakan allah dengan mengenal sifat - sifat Allah atau yang sering di sebut Asmaul husna. 
Dari sini kita tidak hanya mengkaji saja, akan tetapi memahami serta berusaha menunjukkan bahwa kosep atau tatanan tauhid dalam islam adalah Pengesaan Allah sebagai Rabb (zat, sifat serta perbuatannya) dan pengesaan Allah yang patut sebagai illah ( tuhan yang patut di sembah).

\section{B. Konsep Tauhid}

Tauhid adalah menyakini keesaan Allah SWT dalam rububiyyah, ikhlas dalam menjalankan ibadah kepada Allah Subhaanahu Wata'ala, dan menetapkan suluruh nama dan sifat Nya, seperti yang di jelaskan sebelumnya bahwa tauhid ada 3 macam : Tauhid Rububiyyah, Uluhiyyah, Asma'wa sifat. Dari ketiga macam tersebut memiliki makna atau penjelasan yang berbeda, penjelasan tersebut akan di jelaskan di bawah:

a. Tauhid Rububiyyah: yaitu mengesakan Allah SWT dalam segala perbuatannya, dengan cara menyakini bahwa Allah yang menciptakan segenap makhluk hidup. Di dalam tauhid rububiyyah menjelaskan bagaimana menyakini bahwa Allah Esa satu, yang memberi rizky, tuhan yang menciptakan seluruh alam semesta ini.

- Pengertian Rabb dalam Al Quran dan As sunnah: Rabb adalah betuk masdardari kata "Rabba - yurabbi" yang artinya mengembangkan sesuatu dari satu keadaan keadaan yang lainnya, sampai ke keadaan yang sebenarnya. Maka di jelaskan bahwa rabb yang sesungguhnya yaitu Allah SWT,oleh karena itu mengatakan bahwa allah penguasa alam semesta ini dan tuhannya seluruh makhluk di muka bumi ini.

b. Tauhid Ulluhiyyah: Tauhid biasanya di sebut dengan tauhid ibadah karena dari maknanya ma'bud ( yang di sembah) tidak ada yang di serukan kecuali menyambah dan berdoa kepada Allah Subhaanahu Wta'ala. Memohon pertolongan, bergantung 
serta berjanji hanya di perbolehkan kepada Allah SWT maka dari itu tauhid ulluhiyah sebagai bukti bagi umat muslim. Karena banyak yang sering mengingkari tauhid rububiyyah dan ulluhuyyah

c. Tauhid Asma'wasifat: Dalam pengertian tauhid ini menjelaskan nama - nama Allah yang setiap pengucapannya memiliki makna masing - masing dan memperlihatkan sifat yang Allah miliki. Dari Syekh ibn Taimiyah mengatakan ; "setiap nama dari nama namanya menunjukkan dzat yang di sebutkannya dan sifat yang di kandungnnya, seperti al alim menunjukkan Dzat dan ilmu, Al Qadir menunjukkan dzat dan qudrah, Ar rahim menunjukkan Dzat dan sifat rahmat."

Dari ketiga tauhid tersebut telah menjelaskan masing masing yang bersangkutan tenantang Allah SWT. Di dalam Al quran telah menjelaskan tentang tuhan pemilik alam semesta ini yaitu Allah SWT, Allah sang pencipta makhluk hidup, Allah yang mempunyai kendali penuh dalam alam semesta ini, Allah tuhan seluruh makhluk hidup di semesta ini. Keesaan Allah dapat di perlihatkan atau di tunjukkan dengan beberapa pokok antara lain : adanya sesuatu yang terlihat oleh manusia, perasaan hati yang tenang, dan dalil dari al quran serta hadits.

Secara logis tuhan yang kita miliki hanya ada satu, ketika tuhan lebih dari satu maka alam semesta ini akan terpecah belah dan apabila ketika suatu keputusan tidak di kehendaki dengan keputusan yang lain maka tidak akan terwujud. Banyak di antara kita yang masih belum mempercayai tentang adanya tuhan, mereka masih ragu apakah tuhan itu ada, akan tetapi jika di pikir oleh akal sehat kita alam semesta tidak bisa terbangun dengan sendirinya, pasti di sisi lain ada penciptanya, seperti teknologi sekarang teknologi tidak akan maju jika tidak ada yang mempelajari dan menciptakan sesuatu yang baru. 
Akan tetapi kita dapat melihat dan merasakan adanya tuhan, ketika jiwa dan hati kita di penuhi dengan keimanan.

Agama sebenarnya telah mengenalkan kita kepada tuhan kita, sebagaimana yang di jelaskan di ketiga tauhid tersebut. Selain itu banyak pendapat yang mengusulkan bahwa kita dapat menhgetahui tuhan denganbeberapa metode yaitu, metode yang di pakai oleh teolog, metode yang di pakai oleh filosof, dan metode yang di pakai oleh para tasawuf. Dalam ketiga metode ini lebih bertumpu kepada pembuktian akan keberadaan tuhan. Allah sebagai wujud yang tidak dapat di fikirkan melalui logika karena tidak akan tercapai pemikiran akal manusia sehingga tidak ada yang menduakan Allah sebagai bukti bahwa pencipta alam semesta ini. Dari pengertian di atas ada beberapa yang menjadikan pendapat tentang keesaan Allah antara lain :

\section{a. Pendapat kesempurnaan}

Ketika kita mendambakan kesempurnaan, maka akan menemukan tingkat kesempurnaan dan merasakan bahwa dirinya sempurna, akan tetapi dari segi pandang kita masih punya kekurangan. Hal ini dapat di simpulkan bahwa kesempurnaan hanya milik Tuhan yang sempurna dari manusia danyang tidka memilki kekurangan.

\section{b. Pendapat keteraturan}

Keteraturan merupakan sesuatu yang telah mempunyai tatanan sempurna yang di dalamnya memiliki berbagai beragam jenis dan terstruktur rapi. Dari pengertian di atas menjelaskan bahwa alam semesta ini sudah di atur dengan kestrukturan yang telah di atur oleh penciptanya. Contohnya suatu desa yang telah di atur oleh pemimpinnya. Dari sini kita dapat mengetahui bahwa setiap keteraturan ini pasti ada yang menciptakan. 


\section{c. Pendapat keterbatasan dan kebermulaan}

Dalam keterbatasan kita pasti dapat merasakan setiap waktu atau ruang di sekitar kita. Dan di dalam prisip juga dinyatakan " setiap yang terbatas pasti mempunyai keterbatasan, dan setiap yang mempunyai kerangkapan pasti mempunyai rangkapan itu, dalam rangakapan ini berarti adalah akibat bersatunya bagian dan akibat tersebut pasti membutuhkan sebab untuk menjadi ada." . jadi setiap keterbatasan pasti ada awalnya karena awalnya tidak ada dan setiap yang ada berati ada yang mengadakan.

d. Pendapat kemungkinan

Dalam pembahasan tentang keberadaan dapat di bagi menjadi 2 yaitu : ada dan tidak ada. Sesuatu yang bisa di anggap ada maupun tidak ada di sebut wujud. Karena wujud ini bersifat netral, maksudnya menepati posisidada dan tidak secara seimbang, maka keberadaan wujud inidi sebab kan dengan wujud yang lainnnya dan wujud yang lainnya menyebabkan adanya wujud tersebut.

Ada beberapa karakter dalam mengenali tuhan: sederhana, tidak mengalami perubahan dalam semua kondisi, keberadaannya tidak bergantung dengan yang lainnya. Jika melihat keberadaan agama - agama di dunia maka banyak berbagai pandangan terhadap keputusan tuhannya. Seperti yang di ketahui dalam islam menyakini bahwa Allah SWT tuhan yang mutlak tidak ada tuhan selainnya dan tidak ada yang berhak menyekutukannya. Tuhan yang di sembah oleh seluruh makhluk di alam semesta ini. Dan oleh sebab itu kita harus memperkuat fitrah dalam diri setiap muslim

e. Pendapat Neuman Khan mengenai Tuhan

Istrinya berpendapat bahwa, "Tuhan ada, apakah kamu suka atau tidak. Apabila anda tidak percaya tak masalah, bagaimanapun juga Dia akan menghukummu." 
Pada saat itu yang biasa dikatakan oleh orang Arab Badui kuno bahwa aka nada orang dari peradaban lain yang melakukan perdagangan sebelum zaman Islam. Orang-orang Arab masih percaya pada Tuhan walaupun mereka memiliki syirik. Seseorang bertanya kepada orang Arab Badui

"Bagaimana Anda tahu Tuhan itu ada?"

"Kaifa Amanta?" (Bagaimana kamu bisa percaya?)

"Bagaimana Anda meyakininya?"

“Bagaimana keyakinan itu datang kepada Anda?"

Dia menunjuk kotoran unta dan berkata "anda tahu kan tahi? Karena kebiasaan orang Arab yang selalu menghabiskan sebagian waktunya di padang pasir sehingga dapat mengatakan sesuatu yang sangat menarik.

Dia menunjuknya sembari berkata, "Anda mengetahuinya karena itu saya mengetahui bahwa unta saya ada."

Apa maksud perkataan orang Arab Badui tersebut?

Maksudnya adalah ketika kita melihat sesuatu itu ada, merupakan tanda dari sesuatu yang lain. Seperti ketika kita melihat jejak kaki, kita tahu bahwa ada seseorang yang berjalan disini.

Orang Arab Badui melihat seluruh ciptaan sebagai jejak Tuhan. Sama seperti kotoran unta merupakan jejak seekor unta bahwa unta itu pasti ada. Tidak ada keraguan dalam pikirannya.

\section{f. Mengenali Diri Sendiri Akan Mengenal Tuhan}

Untuk memahami Tuhan, kita harus memahami tentang diri kita sendiri. Dalam sebuah hadits Nabi shallallahu alaihi wa sallam. Beliau bersabda, "Man 'arofa nafsahu 'arofa robbahu." 
Siapapun yang benar-benar mengenal dirinya sendiri, mereka akan benar-benar mengenal Tuhannya.

Apabila kita benar-benar mengenal siapa diri kita, maka kita akan tahu siapa Tuhan yang patut disembah. Kita harus menelusuri maksud pernyataan tersebut melalui Al-Qur'an, sehingga dapat memahami apa yang Nabi Muhammad Shallallahu Alaihi Wasallam sampaikan kepada kita

Bagaimana cara kita bisa mengenal Allah? Siapa yang harus kita kenal sebelum mengenal Allah? Jawabannya adalah kita harus mengenal diri kita sendiri terlebih dahulu. Apabila kita sudah benarbenar mengenal siapa kita, diri kita sendiri, maka kita akan dapat mengetahui siapa Allah.

\section{“Apa maksudnya kita tidak mengenal diri kita sendiri?”}

Ada bagian lain dari diri kita yang tidak benarObenar diketahui dengan baik. Bagian itu merupakan bagian dari diri kita yang Allah ciptakan sebelum kita berada di bumi ini dan bagian dari kita yang sudah Allah ciptakan sebelum keluar dari perut ibu kita. Itu semua sudah ada dan merupakan bagian dari diri kita

\section{Evaluasi}

1. Baca teks ini dengan seksama, kemudian lakukan paraphrase (encoding) di setiap sub babnya!

2. Buat sebuah komentar menggunakan Thesis annotation, The probe annotation, Personal view annotation, dan Inventive annotation terhadap teks di atas untuk mengomentari setiap sub-babnya!

3. Buat kelompok diskusi setiap kelompok terdiri dari 5 orang mendiskusikan masalah-masalah berikut dan tuliskan hasil diskusinya:

a. Definisi Tauhid 

b. Pembagian Tauhid
c. Argumentasi Tauhid

\section{Referensi}

Abdu I-Muhsin, 'Abdu r-Razzaq bin. Al-Qaul Al-Sadid Fi Ar-Raddi 'Ala Man Ankara Taqsima t-Tauhid. Edited by Dar Ibnu L-Qayyim. 1st ed. Riyad, 2003.

Al-Maqrizi, Taqiyuddin Ahmad bin Ali. Tajridu T-Tauhid Al-Mufid. Kairo: Markaz I-Kitab li n-Nashr, n.d.

Al-Maturidi, Abu Manshur Muhammad bin Muhammad. Kitab At-Tauhid. Beirut: Dar Shadir, 2001.

Al-Qahtani, Sa'id bin 'Ali bin Wahf. Nur T-Tauhid Wa Dhulmatu s-Shirk Fi Dau'i I-Kitab Wa s-Sunnah. 3rd ed. Riyad: Maktabah Malik Fahd, 2000.

Al-Wali, Husain. Kitab Kalimatu T-Tauhid. 1st ed. Mesir: Maktabah Al-Wa'idz, 1908.

Jabbar, Abdul. Al-Mughni Fi Abwabi t-Tauhid Wa I-'Adl. Mesir: Wizarah AlThaqafah Al-Mishriyyah, n.d.

Yasri, Muhammad. 'Ilmu t-Tauhid 'Inda Ahl s-Sunnah Wa I-Jama'Ah. 1st ed. . سلسلة المدخل المفيد إلى علم التوحيد 1, Islamkotob.com.

Al-Ghazali, Abu Hamid. Ihya' Ulumuddin. 1st ed. Beirut: Dar Ibnu Hazm, 2005.

- - Tahafut Al-Falasifah. Edited by Sulayman Dunya. 6th ed. Kairo: Daru I-Ma'arif, 1980.

Ibnu Sina, Abu 'Ali Al-Husain. Al-Risalah Al-'Arshiyyah Fi Tawhidihi Ta'Ala Wa Sifatuhu. 1st ed. Omman: Matabi' Dairah al-Ma'arif al-'Amaniyyah, 1934.

-- - An-Najah Fii I-Mantiq Wa I-Ilahiyyat. Edited by Majid Fakhry. Beirut: Daru I-Afaq Al-Jadidah, 1982. 


\section{TEKS IX}

\section{KEKUASAAN DAN KEHENDAK ALLAH SWT \\ DAN KAITANNYA DENGAN PERBUATAN MANUSIA}

Pada dasarnya Kehendak Allah adalah suatu konsep yang berisi rencana Allah tentang suatu hal yang terjadi kepada seluruh makhluk yang diciptakan-Nya, seperti manusia, malaikat, jin dan segala seuatu ciptaan Allah.

Kehendak Allah adalah asal mula terjadinya/timbulnya segala sesuatu. Segala sesuatu yang dikehendaki oleh Allah pasti akan terjadi, dan segala sesuatu yang tidak dikehendaki-Nya tidak akan pernah terjadi. Allah yang telah menciptakan dan mengatur alam semesta termasuk makhluk ciptaan yang ada di dalamnya, tentu saja pasti Allah yang mempunyai kehendak dan kekuasaan terhadap makhluknya.

Manusia sebagai salah satu makhluk ciptaan Allah, manusia mempunyai kehendak untuk menentukan perbuatannya tapi, kehendak manusia harus disandarkan pada kehendak Allah, karena kehendak manusia tergantung pada kehendak Allah. Sebagai salah satu ayat Al-Qur'an yang menjelaskan mengenai hal tersebut terdapat dalam surat Al-Kahfi ayat 23 dan 24 yang artinya: Dan jangan sekali-kali engkau mengatakan terhadap sesuatu, "aku pasti melakukan itu esok hari". Kecuali (dengan mengatakan) "Insya Allah". Dan ingatlah kepada Tuhanmu apabila engkau lupa dan katakanlah, "Mudah-mudahan Tuhanku akan memberiku petunjuk kepadaku agar aku yang lebih dekat (kebenarannya) daripada ini".

Maksud dari ayat tersebut adalah, siapa saja yang hendak atau berencana ntuk melakukan sesuatu di esok hari, hendaknya ia 
menyandarkan kekuatan dan izin dari Allah. Manusia bisa melakukannya dengan mengucapkan "Insya Allah" yang memiliki arti "jika Allah menghendaki". Sebab semua tidak akan mampu berbuat sesuatu apapun tanda dikendaki oleh Allah.

Akan tetapi, apakah kehendak dan kekuasaan Allah bersifat mutlak atau terbatas, terdapat beberapa perbedaan pendapat mengenai masalah ini. Sebagian ada yang berpendapat bahwa kekuasaan dan kehendak Allah berfifat mutlak, namun sebagian yang lain ada yang berpendapat bahwa akal manusia memiliki daya yang besar, maka kekuasaan dan kehendak Allah tidaklah bersifat mutlak semutlak-mutlaknya. Diantara perbedaan pendapat dalam aliranaliran teologi islam terhadap kekuasaan dan kehendak Allah yaitu:

\section{$>$ Mu'tazilah}

Kaum Mu'tazilah berpendapat bahwa manusia telah diberi Allah kemerdekaan dan kebebasan dalam menentukan kehendak dan perbuatannya. Oleh karena itu, bagi kaum mu'tazilah Allah tidak bersifat mutlak dan terbatas. Pandangan kaum mu'azilah, kekuasaan dan kehendak mutlak Allah berlaku dalam jalur hukum-hukum yang tersebar di tengah alam semesta. Karena itulah kemutlakan kehendak Allah menjadi terbatas. Sedangkan yang menciptakan perbuatan adalah manusia sendiri. Karena Allah menciptakan manusia selakigus menciptakan kemampuan dan kehendak pada diri manusia.

Kaum Mu'tazilah menguatkan pendapatnya dengan didasarkan pada dalil aqli dan naqli. Secara aqli, mereka menyatakan apabila manusia tidak diberikan kehendak oleh Allah, maka manusia itu tidak akan dibebani suatu kewajiban. Adapun secara naqli didasarkan pada ayat Al-Qur'an surat Al-Kahfi ayat 29.

$>$ Asy'ariyah 
Pendapat kaum asy'ariyan bertolak dengan pendapat kaum mu'tazilah. Kaum asy'ariyah mengatakan bahwa Allah memiliki kehendak dan kekuasaan yang mutlak. Allah dapat berbuat apa saja terhadap makhluknya sesuai dengan kehendak dan kekuasaa-Nya tanpa ada yang mampu membatasi dan melarangnya. Kaum asy'ariyan memperkuat pendapatnya menggunakan dalil aqli dan naqli. Secara aqali kaum ini menyatakan bahwa perbuatan Allah itu berasal dari qusrat dan iradah-Nya secara sempurnya dan mutlak. Sedangkan secara naqli didasarkan pada Al-Qur'an surat As-Shaffat ayat 96 .

$>$ Maturidiyah

Aliran maturidiyah dalam hal ini mengambil posisi tengah antara pendapat mu'tazilah dan Asy'ariyah. Maturidiyah berpendapat bahwa Allah berkehendak dalam hal baik dan buruk, tetapi bukan berarti Allah sewenang-wenang dalam menentukan kehendaknya, kehendak yang dimaksudkan terjadi sesuai dengan hikmah dan keadilan yang sudah ditentukan.

$>$ Qodariyah

Aliran Qodariyah berpendapat bahwa manusia memiliki kebebasan dan kemerdekaan dalam berkehendak dan menentukan perbuatannya. Allah memberikan akal pada manusi untuk digunakan berfikir, jadi aliran ini berpendapat bahwa manusia berkendak dalam menentukan perbuatan baik dan buruk karena manusia diberi akan untuk membedakan baik dan buruk. Pendapat ini didasarkan pada Q.S Ar-Ra'du ayat 11 yang artinya "Sesungguhnya Allah tidak akan merubah keadaan suatu kaum, sehingga mereka merubah keadaan dirinya sendiri".

$>$ Jabariyah 
Aliran jabariyah menolak pendapat aliran qodariyah. Aliran jabariyah berpendapat bahwa manusia tidak memiliki kehendak dan kebebasan dalam menentukan perbuatannya. Aliran ini percaya bahwa manusia tidaklah menciptakan perbuatannya sendiri tetapi manusia memperoleh perbuatan yang sudah diciptakan oleh Allah. Pendapat ini didasarkan pada Q.S Al-Insan ayat 30 yang artinya "Dan kamu tidak mampu (menempuh jalan itu), kecuali bila dikehendaki Allah. Sesungguhnya Allah maha Mengetahui lagi Maha Bijaksana".

Kehendak Allah dalam pandangan islam adalah salah satu sifat dari beberapa sifat-sifat Allah. Allah memiliki kehendak akan terjadinya atau tidak terjadi sesuatu terhadap makhluknya. Percaya akan kehendak Allah merupakan bentuk iman kepada qadha dan qadharnya Allah.

Allah SWT wajib dan pasti memiliki sifat iradah yaitu sifat qadim dan berada di dalam Dzat-Nya yang dengan sifat itu Allah SWT menentukan segala sesuatu yang mungkin pada sebagian kemungkinannya. Dan mustahil bagi Allah SWT memiliki kebalikan dari sifat ini, yaitu karahah (keterpaksaan).

Dalil ketetapan sifat ini adalah bahwa alam tidak tercipta dengan sendirinya, namun tercipta dari Allah SWT. Jika demikian maka terciptanya alam dari Allah SWT bisa jadi melalui hubungan sebab akibat dan secara otomatis tanpa ada kehendak serta pilihan. Atau tercipta melalui kehendak dan pilihan-Nya. Artinya, Dialah dzat yang menghendaki dan memilih wujudnya alam, serta menentukan waktu dimana alam diwujudkan.

Hal yang tidak masuk akal jika terciptanya alam dari Allah SWT melalui hubungan sebab akibat, tanpa ada pilihan dari-Nya (untuk menciptakan dan tidak menciptakan). Sebab, seandainya kenyataannya demikian (sedangkan Allah SWT adalah Dzat yang 
qadim) niscaya alam itu qadim, karena alam adalah akibat dari keberadaan Allah SWT dan akibat selalu mengekor pada sebabnya, tidak bisa tertinggal dari sebabnya.

Padahal telah ditetapkan bahwa alam sesuatu yang baru, ada setelah tidak ada. Oleh karena itu, terciptanya alam dari Allah SWT tidaklah melalui hubungan sebab akibat. Sehingga tidak tersisa kemungkinan kecuali wujudnya alam berdasarkan kehendak dan pilihan-Nya, serta penentuannya terhadap waktu dimana alam di wujudkan. Dengan uraian ini dapat disimpulkan bahwa Allah SWT adalah Tuhan pencipta alam yang berkehendak dan bebas memilih, sehingga wajib baginya sifat iradah dan mustahil baginya sifat keterpaksaan.

Allah SWT wajib bersifat qudrah, yaitu sifat yang qadim yang berada di dalam Dzat-Nya yang dengannya Allah SWT menciptakan makhluk dan meniadakannya. Mustahil baginya kebalikan dari sifat ini yaitu 'ajz (tidak berdaya). Dalil mengenai sifat ini adalah penciptaan Allah SWT terhadap alam semesta beserta komponen yang ada didalamnya. Seperti dunia binatang, tumbuh-tumbuhan dan logam yang menyimpan jutaan jenis, yang keagungan dan keajabannyamembingungkan akal dan menenggelamkan pemahaman.

Akal yang sehat tidak akan membenarkan (bahkan merupakan hal yang jelas mustahil menurut akal) jika pencipta alam semesta dengan segenap keagungan dan keanehannya ini adalah Dzat yang lemah dan tidak berdaya. Dengan uraian ini dapat ditetapkan bahwa Allah SWT Tuhan yang mewujudkan alam semesta beserta keagungan dari ketiadaan, Allah SWT wajib memiliki sifat qudrah (kekuasaan), dan mustahil Allah SWT besifat lemah atau tidak berdaya. 
Kekuasaan berasal dari kata kuasa. Kuasa merupakan salah satu dari sifat-sifat yang dimiliki Allah, yaitu Maha kuasa atau biasa disebut dengan sifat Qudrat. Qudrat atau kuasa Allah adalah sifat yang wujud atau tetap pada dzat Allah ta'ala, dengan adanya sifat qudrat mudah bagi Allah untuk menciptakan atau meniadakan sesuatu yang bersifat mungkin. Sebagai contoh Allah yang menciptakan seluruh makhluk hidup di bumi dan kelak Allah akan menghancurkan bumi di hari kiamat.

Allah adalah dzat yang Maha kuasa dengan kekuasaan yang tidak terbatas. Kekuasaan Allah SWT meliputi segala sesuatu, hal ini sudah tercantum pada firman Allah Q.S. al-Hasyr ayat 6 yang artinya "Dan Allah Maha Kuasa atas segala sesuatu". Sebagai umat muslim hendaknya kita percaya akan kekuasaan Allah SWT.

Secara global, sifat qudrat Allah memiliki 2 ta'alluq (hubungan), yang pertama ta'alluq shuluhi qodim, kedua ta'alluq tanjizi hadist. Ta'alluq Shuluhi Qodim adalah kelayakan sifat Qudrat Allah di masa sebelum terciptanya makhluk dan alam semesta, hanya terdapat Dzat Allah semata untuk menciptakan dan meniadakan makhluknya. Sedangkan pengertian dari ta'alluq tanjizi hadist adalah hubungan dimana Allah SWT menciptakan dan meniadakan makhluk dengan fakta yang nyata, seperti segala sesuatu yang ada dan tidak ada di alam semesta ini.

Bukti nyata tentang adanya kekuasaan Allah adalah Allah telah menciptakan Alam semesta beserta isi di dalamnya, khusunya langit. Dalam menciptakan alam semesta Allah tidak membutuhkan bantuan siapa-siapa. Allah telah banyak menjelaskan dalam A-Qur'an mengenai bukti-bukti kekuasaan dan kebesaran-Nya. Salah satunya terdapat dalam Q.S. al-Naml ayat 93 yang artinya, "Dan katakanlah(Mauhammad), segala puji bagi Allah, Dia akan memperlihatkan kepadamu tanda-tanda kebesaran-Nya, maka kamu 
akan mengetahui dan Tuhanmu tidak lengah dari apa yang kamu kerjakan".

Dalam Al-Qur'an, Allah memerintahkan agar manusia berfikir dan merenungkan mengenai kekuasaan Allah dalam ciptaan-Nya. Jika manusia mau berfikir dan merenungkan, maka ia akan menyadari bahwa seluruh alam semesta ini adalah bukti dari kekuasaan Allah SWT. Sungguh, adalah kewajiban bagi manusia untuk mengenal tanda-tanda kekuasaan Allah, dengan begitu manusia akan mengenal pencipta yang telah menciptakan dirinya dengan segala sesuatunya dan akan menjadikan manusia lebih dekat dengan Allah SWT.

Bukti kekuasaan Allah dalam menciptakan seluruh alam semesta yang ada saat ini, terdapat dalam Q.S. Al-Baqarah ayat 164 yang memiliki arti "Sesungguhnya pada penciptaan langit dan bumi, pergantian malam dan siang, kapal yang berlayar di laut dengan (muatan) yang bermanfaat bagi manusia, apa yang diturunkan Allah dari langin berpa air, lalu dengan itu dihidupkan-Nya bumi setelah mati (kering). Dan Dia tebarkan di dalamnya macam-macam binatang, dan perkisaran angin dan awan yang dikendalikan antara langit dan bumi, (semua itu) sungguh, merupakan tanda-tanda (kebesaran Allah) bagi orang-orang yang mengerti.

Alam semesta yang sudah diciptakan Allah ini bagaikan rumah yang segala sesuatunya sudah terpenuhi, langit yang ditinggakan ibarat sebagai atap rumah, bumi yang dihamparkan ibarat sebagai lantainya, bintang-bintang dijadikan hiasan ibarat sebagai pelita. Allah SWT telah menciptakan langit dengan perpaduan warna yang sejuk dipandang mata dan tidak ada satupun manusia yang mampu menyerupai ciptaan-Nya yang sempurna.

Dalam penciptaan langit,terdapat beberapa ayat Al-Qur'an yang menjelaskan mengenai hal itu, salah satunya terdapat dalam 
Q.S. Qof ayat ke 6 yang artinya, "Maka tidaklah mereka memperhatikan langit yang ada diatas mereka, bagaimana cara kami membangunnya dan menghiasinya, dan tidak ada retak-retak sedikitpun". Dalam ayat ini Allah memerintahkan manusia untuk berfikir dan percaya adanya Kuasa Allah. Dan masih banyak juga ayatayat lain yang berkaitan dengan penciptaan langit.

Dalam Al-Qur'an bintang diungkap dengan kata Najm, Najm diungkapkan dalam bentuk tunggal (najm) dan ada pula bentuk jamak (nujum). Dibalik Allah menciptakan bintang terdapat tujuan bagi manusia dan mengenai hal itu Allah sudah menjelaskannya dalam Q.S. al-Hijr ayat 16 yang memiliki arti, "Dan sungguh telah kami ciptakan gugusan bintang di langit, da menjadikannya terasa indah bagi orang-orang yang memandanginya".

Allah SWT telah menciptakan alam semesta dengan keadaan yang seimbang, sehingga kelangsungan hidup dan proses di alam semesta bisa berjalan dengan baik dan harmonis. Maka dengan memahami kekuasaan dan kebesaran Allah diharapkan Manusia mampu merenungi ciptaan-ciptaan Allah sehingga manusia dapat melihat siapa Tuhan dan penciptanya, dan juga dapat meningkatkan kualitas keimanan kepada Allah bagi orang-orang beriman.

Ada sebuah kisah, seorang ayah yang sholih, bijaksana dan sukses hidup bersama keluarganya dengan bahagia. Setelah sang ayah berusia 65 tahun terkena serangan jantung dan harus menjalani oprasi dan dirawat dirumah sakit. Setelah melakukan dua kali oprasi, sang ayah tidak kunjung membaik, bahkan keadaanya semakin buruk karena dinyatakan terinfeksi oleh virus ketika menjalani tranfusi darah, dan sang dokter telah memfonis bahwa hidupnya tidak akan lama lagi. 
Wajah yang pucat dan rambut yang habis karena rontok, melihat keadaan ayahnya yang tidak berdaya seperti itu anaknya yang duduk disampingnya berkata:"Mengapa Allah memilih ayahku untuk menderita penyakit ini?". Kemudian sang ayah menjawab perkataan anaknya dengan suara lembut, sang ayah berkata:"Ketika aku berhasil sewaktu dulu, aku tidak pernah bertanya kepada Allah 'mengapa aku berhasil ya Allah' begitu pula saat aku diberi kesehatan, apukun tidak pernah bertanya 'mengapa aku sehat', jadi ketika aku dalam kesakitan seperti ini tidak seharusnya pula aku bertanya pada Allah 'mengapa aku menderita penyakit?'.

Dalam hidup ini, terkadang manusia merasa hanya pantas menerima hal-hal yang baik saja, kesuksesan dalam hidupnya dan kesehatan tanpa rasa sakit. Ketika manusia menerima hal yang sebaliknya seperti penyakit, kegagalan dan kesulitan manusia menganggap bahwa Allah tidaklah adil sehingga manusia merasa berhak ntuk menggugat-Nya.

Maka, kita sebagai manusia yang beriman hendaklah bersyukur atas apa yang sudah diberikan Allah kepada kita. Baik itu kesehatan atau penyakit, keberhasilan ataupun kegagalan, sesuatu yang baik maupun yang buruk. Allah Maha Kuasa dan memiliki segala kehendak yang tidak terbatas sedangkan manusia itu lemah dan juga memiliki keterbatasan.

\section{Evaluasi}

1. Baca teks ini dengan seksama, kemudian lakukan paraphrase (encoding) di setiap sub babnya!

2. Buat sebuah komentar menggunakan Thesis annotation, The probe annotation, Personal view annotation, dan Inventive annotation terhadap teks di atas untuk mengomentari setiap sub-babnya! 
3. Buat kelompok diskusi setiap kelompok terdiri dari 5 orang mendiskusikan masalah-masalah berikut dan tuliskan hasil diskusinya:

a. Bagaimana sifat qudrah menurut para Madhab

b. Argumentasi bahwa Allah pasti punya sifat Qudrah

\section{Referensi}

Abdu I-Muhsin, 'Abdu r-Razzaq bin. Al-Qaul Al-Sadid Fi Ar-Raddi 'Ala Man Ankara Taqsima t-Tauhid. Edited by Dar Ibnu L-Qayyim. 1st ed. Riyad, 2003.

Al-Maqrizi, Taqiyuddin Ahmad bin Ali. Tajridu T-Tauhid Al-Mufid. Kairo: Markaz I-Kitab li n-Nashr, n.d.

Al-Maturidi, Abu Manshur Muhammad bin Muhammad. Kitab AtTauhid. Beirut: Dar Shadir, 2001.

Al-Qahtani, Sa'id bin 'Ali bin Wahf. Nur T-Tauhid Wa Dhulmatu s-Shirk

Fi Dau'i I-Kitab Wa s-Sunnah. 3rd ed. Riyad: Maktabah Malik Fahd, 2000.

Al-Wali, Husain. Kitab Kalimatu T-Tauhid. 1st ed. Mesir: Maktabah AlWa'idz, 1908.

Jabbar, Abdul. Al-Mughni Fi Abwabi t-Tauhid Wa I-'Adl. Mesir: Wizarah Al-Thaqafah Al-Mishriyyah, n.d.

Yasri, Muhammad. 'Ilmu t-Tauhid 'Inda Ahl s-Sunnah Wa I-Jama'Ah.

1st ed. سلسلة المدخل المفيد إلى علم التوحيد 1, Islamkotob.com. Al-Ghazali, Abu Hamid. Ihya' Ulumuddin. 1st ed. Beirut: Dar Ibnu Hazm, 2005.

- - Tahafut Al-Falasifah. Edited by Sulayman Dunya. 6th ed. Kairo: Daru I-Ma'arif, 1980.

Ibnu Sina, Abu 'Ali Al-Husain. Al-Risalah Al-'Arshiyyah Fi Tawhidihi Ta'Ala Wa Sifatuhu. 1st ed. Omman: Matabi' Dairah alMa'arif al-'Amaniyyah, 1934.

- - . An-Najah Fii I-Mantiq Wa I-Ilahiyyat. Edited by Majid Fakhry. Beirut: Daru I-Afaq Al-Jadidah, 1982. 


\section{TEKS $X$}

\section{KALAMULLAH}

Kalam Allah atau jika diartiakan secara bebas menjadi ucapan Allah, kalam Allah biasa disebut dengan kalamullah. Pembahasan mengenai kalamullah ini merupakan suatu bahasan yang ada sejak ratusan tahun yang lalu tepatnya sejak zaman ketika Rasulullah telah meninggal dunia. Pembahasan mengenai kalamullah ini telah menjadi sebuah persoalan teologi dalam tubuh umat islam karena beberapa pendapat yang muncul mengenai hal ini saling bertolak belakang antar golongan yang ada dalam islam.

Kalam Allah berbeda dengan kalam manusia karena jika kalam ialah perkataan manusia maka teolog dalam islam ilm al kalam, karena teolog islam saling berpendapat dengan menggunakan kata-kata dan mencoba menjadikan argumentnya menjadi suatu argumentasi yang kuat dan tidak terpatahkan oleh pendapat yang lainnya.

\section{A. Pengertian Kalamullah}

Kalamullah jika diartikan secara kebahasaaan berarti ucapan atau perkataan Tuhan, sedangkan secara istilah kalamullah memeiliki dua pengertian jika hal ini didasarkan pada golongan Ahlussunnah, dua pengertian itu antara lain:

a. Kalam berarti lawan dari bisu, hal ini dikarenakan Allah tidak mungkin bisu karena Allah Maha berbicara yang ada sejak dahulu tanpa adanya awalan (azali). Tidak seperti manusia yang memiliki awalan dalam berbicara yaitu saat mulai beranjak dewasa, karena itulah kalam memiliki arti lawan dari kebisuan. 
b. Kalam diartikan sebagai lawan dari diam, karena suatu kemustahilan jika Allah diam. Karena Allah maha berkehendak untuk berbicara kepada siapapun yang dikehendakinya.

Kalamullah merupakan sifat Allah yang kekal dan Qadim dengan segala kesempurnaanya, serta kalamullah memiliki kaitan yang cukup erat dengan segala sesuatu yang Allah ketahui dan dengan-Nya lah bersabda mengenai perintah, jani-janji serta ancaman-Nya. Kalam berarti ucapan bukan berarti memiliki suara atau tersusun atas huruf-huruf karena jika disamakan dengan kalam manusia yang tersusun atas huruf dan suara maka sifat Allah berarti tidak mungkin sama dengan makhluk akan tidak berlaku seperti yang tercermin dari firman Allah surat As-Syuuara ayat 11, sedangkan dalam kenyataanya Allah tidak mungkin sam dengan makhluk karena itulah kalamullah tidak tersusun atas suara dan huruf.

\section{B. Kalamullah menurut beberapa golongan islam}

\section{Kalamullah menurut golongan Mu'tazilah}

Menurut golongan Mu'tazilah kalamullah dalam pembahasan ini adalah kitab suci Al-Quran yang disebut sebagai makhluk oleh golongan mu'tazilah. Hal itu berarti Al-Qur'an tidak termasuk bagian dari Allah yang bersifat qadim karena diciptakan dan merupakan sesuatu yang baru. Golongan Mu'tazilah memiliki pendapat seperti itu karena pemikiran Mu'tazilah sebelumnya yang berpandangan bahwa Tuhan tidak mempunyai sifat sebagai suatu hal yang tidak bersatu dengan zat Tuhan sendiri, sehingga menyimpulkan bahwa kalamullah (Al-Qur'an) merupakan makhluk

Menurut golongan ini kalamullah tersusun atas huruf-huruf dan suara serta kalimat. Karena itulah Mu'tazulah berpendapat bahwa AlQur'an terdiri dari kata-kata, sedangkan kata-kata itu merupakan hal 
baru yang tidak kekal, maka dari pendapat itu dapat ditarik kesimpulan bahwa Al-Qur'an bukan merupakan bagian dari Qadim karena bagi Mu'tazilah tidak ada yang Qadim kecuali Allah itu sendiri. golongan ini berpendapat bahwa Al-Qur'an bukanlah sesuatu yang qadim karena memahami bahwa Al-Quran tersusun dari bagianbagian surat yang didalamnya terdiri dari beberapa ayat yang turun terlebih dahulu dan kemudian turun ayat yang lain, ayat satu mendahului ayat lainnya, sehingga karena adanya sifat terdahulu dan sifat yang akan dating kemudian, membuat sesuatu tersebut tidak bias menjadi qadim. Mu'tazilah berpendapat demikian karena berdasarkan beberapa ayat yang terdapat dalam Al-Qur'an yaitu surat Al-Anbiya ayat 2 , surat Al-Hijr ayat 9, surat Hud ayat 1 , dan AzZumar ayat 23.

Selain itu pembahasan yang masih berhubungan dengan kalamullah adalah mengenai fungsi dari wahyu bagi umat manusia, dalam hal ini Mu'tazilah berpendapat bahwa wahyu tidak memiliki fungsi apa-apa untuk mengetahui Tuhan dan sifat-sifatnya tetapi untuk cara memuja tuhan wahyu diperlukan, Fungsi wahyu yang lainnya bagi Mu'tazilah adalah untuk mengingatkan manusia akan kelalaian mereka dan memperpendek jalan mengetahui Tuhan. Sehinga dapat disimpulkan bahwa fungsi wahyu bagi Mu'tazilah lebih bersifat konfirmasi dibanding memberikan informasi.

Dari berbagai macam argumentasi yang dibangun oleh Mu'tazilah diatas dapat ditari sebuah kesimpulan bahwa Al-Qur'an merupakan makhluk yang diciptakan dan bukan merupakan bagian dari sifat Tuhan yang kekal yang ada sejak zaman azali.

\section{Kalamullah menurut golongan Asy'ariyah}


Al-Asy'ariyah adalah bagian lain dari golongan-golongan teologi islam, golongan ini pertama kali dicetuskan oleh Abu al-Hasan 'Ali Ibn Ismail al-Asyari lahir di asrah tahun $873 \mathrm{M}$. Wafat di Baghdad pada tahun $935 \mathrm{M}$. Golongan ini merupakan golongan yang pendapatnya sangat berbeda dengan golongan Mu'tazilah, termasuk dalam hal pembahasan mengenai kalamullah. Golongan Asy'ariyah memiliki pendapat yang berbanding terbalik dengan pendapat golongan Mu'tazilah.

Aliran Asy'ariyah berpendapat berbeda dengan golongan Mu'tazilah, menurut golongan yang dibawa oleh Abu Hasan Al Asy'ari ini kalam Allah itu merupakan sesuatu yang menjadi satu dengan Allah sehingga sifatnya qadim, sedangkan dalam hal perintah dan larangan merupakan keterangan yang terdapat dalam kalam-Nya dan bukan merupakan sesuatu yang bisa terbilang jumlahnya dalam kalam tersebut. Dengan dasar keterangan inilah golongan ini melihat bahwa Kalamulah menjadi dua bentuk yakni, kalamullah merupakan sifat Tuhan yang Qadim dan lafaz yang ada di dalam kalam terbutlah yang merupakan hal baru dan bersifat baru sehingga disebut dengan makhluk.

Dengan berpendapat demikian maka golongan Asy'ariyah juga berbeda pendapat dalam hal sabda. Menurut golongan ini sabda merupakan bagian dari sifat Tuhan sehingga karena bagian dari sifat maka sabda itu merupakan sesuatu yang abadi. Ucapan bukan tersusun dari huruf dan dikeluarkan dengan suara tetapi ucapan yang tersusun tersebut bukan merupakan arti yang sesungguhnya, ucapan yang sesungguhnya letaknya ada di dalam yang tersusun tersebut.

Ucapan yang disusun dari kumpulan huruf-huruf dan dikeluarkan dalam bentuk suara tidak berartu ucapan Tuhan atau sabda Tuhan karena sabda yang memiliki arti tersiratlah yang sifatnya 
kekal dan menjadi bagian dari sifat Tuhan sehingga golongan ini tetap berpendapat bahwa Al-Qur'an adalah Qadim dan tidak diciptakan.

Asy'ariyah tetap memegang teguh terhadap pendapatnya yang berupa bahwa Al-Qur'an bukanlah makhluk karena semua yang tercipta setelah Allah berfirman jadilah maka semua sesuatu itu menjadi ada, sehingga dari argument ini telah memberikan sebuah tanda yang menjelaskan Al-Qur'an itu tidak tersusun dari huruf dan suara, melainkan yang ada di balik huruf dan suara tersebut. Argument ini di lontarkan oleh Al-Asy'ari berdasar pada firman Allah surat Ar-Rum: 109, Al-'Araf: 54, Yasin: 82, Al-Kahfi: 109, dan AlMu'min: 16.

Menurut Asy'ari kata kun merupakan kata yang digunakan dalam setiap penciptaan, jika kata kun diciptakan maka untuk menciptakan kata kun itu perlu adanya kun yang lain sehingga menciptakan rentetan kata kun yang tidak berkesudahan. Karena itulah Al-Qur'an disebut bersifat kekal dan tidak diciptakan.

Dalam membahas mengenai kalamullah sendiri tidak dapat dilepaskan pula mengenai pembahasan tentang fungsi wahyu yang merupakan bagian dari kalamullah. Menurut golongan ini wahyu memiliki fungsi wahyu adalah untuk mengatur kegiatan manusia kemudian memberikan tuntunan kepada manusia dalam segala aspek kehidupan.

Dari argumentasi yang disampaikan oleh golongan ini maka dapat diambil sebuah kesimpulan bahwa kalamullah dalam hal ini Al-Qur'an tidaklah makhluk yang diciptakan tetapi merupakan bagian dari Tuhan sendiri yang sifatnya qadim atau kekal yang ada sejak zaman azali. Sedangkan yang merupakan makhluk adalah susunan yang terbentuk dari huruf dan suara yang bukan bagian dari Al-Qur'an 
yang abstrak sehingga argumentasinya dapat diuaraikan sebagai berikut:

a. Al-Qur'an adalah termasuk ilmu Allah, karena itu ia tidak dapat dipisahkan dengan ilmu-Nya yang Qadim.

b. Allah menciptakan sesuatu dengan lafadz "kun". Jika kun itu baru maka Kun tersebut menjadi pencipta selain Allah. Oleh karena itu ia harus Qadim.

c. Dalam Al-Qur'an, Allah membedakan antara Khalq dan 'Amr. Ini berarti bahwa 'Amr (termasuk kalam Allah) itu bukan makhluk.

\section{Kalamullah menurut golongan Maturidiyah}

Maturidyah merupakan salah satu golongan lain dalam islam yang membahas mengenai teologi, Maturidiyah ini dipelopori oleh Abu Mansur Muhammad Ibn Mahmud al Maturidi lahir di Samarkand pada pertengahan kedua dari abad ke-9 M dan meninggal tahun 944 M

Kalamullah menurut Maturidiyah sama dengan pendapat yang dilontarkan oleh Asy'ariyah. Kalamullah menurut pemikiran AlMaturidi antara lain: Kalamullah bukanlah makhluk dan hakikat kalam itu sendiri adalah kiasan dan tidak dapt didengar, artinya dibalik yang tersusun itu adalah kekal, yang tersusun itu bukanlah sabda Allah melainkan tanda dari sabda Allah.

a. Kalamullah adalah makna yang ada pada dzatnya

Maturidiyah mengatakan bahwa kalamullah bukan berbentuk huruf-huruf atau kalimat, bukan pula berupa suara dan 
tidak dapat didengar suaranya. Kalamullah bersifat qadim dan tidak diciptakan, kekal, satu dan tidak terbagi.

b. Kalamullah bukan makhluk

Sama dengan pendapat yang dilontarkan oleh Asy'ari, AlMaturidi menyatakan bahwa kalamullah bersifat qadimah dan makna yang berdiri di dalam dzat Allah sehingga jelaslah bahwa kalamullah bukanlah makhluk yang bersifat hadist.

c. Hakikat kalam tidak dapat didengar kecuali majazi

Al-Maturidi menyatakan bahwa kalam tidak dapat didengar kecuali majazi (kiasan). Yang didengar adalah suara yang kemudian bias dipahami dari kalam dan ucapan. Hal ini menunjukkan makna majazinya dan bukan makna hakikinya. Al-Maturidi membedakan antara kalam (ucapan) dengan qira'ah. Hal ini berbeda dengan pandangan mu'tazilah yang menyatakan bahwa qira'ah sama halnya dengan kalam. Menurut Al-Maturidi kalamullah terbagi menjadi dua, yakni:

1) Kalam al-nafs, yaitu kalam yang terdapat dalam dzat Tuhan itu sendiri sehingga kalam ini sifatnya kekal. Kalam ini tidak seperti kalam manusia yang memiliki huruf dan suara melainkan kala mini msudah menjadi sifat Tuhan sejak azali dan tidak dapat diketahui secara pandangan hakikat serta tidak bisa didengar tanpa sebuah perantara.

2) Kalam al-lafz, adalah kalam yang terdiri dari susunan huruf dan suara sehingga kala $m$ ini merupakan hal baru yang sifatnya adalah makhluk karena sama dengan kalam manusia.

Dalam menjelaskan mengenai sabda, Maturidi memiliki pandangan yang serupa dengan golongan Asy'ariyah yakni dalam arti 
yang tersirat atau abstrak bukan berbentuk susunan. Sabda tidaklah huruf, tidak juga suara, sehingga hanya berbentuk arti yang tidak sesungguhnya, sehingga sabda berarti memiliki makna yang ada di dalam suatu susunan itu adalah abadi. Sehingga yang tersusun itu bukanlah sabda Tuhan tetapi tanda-tanda dari sabda itu sendiri.

\section{Kalamullah menurut golongan Jahmiyah}

Sama halnya dengan beberapa golongan islam yang lainyang telah disebutkan diawal, Jahmiyah merupakan salah satu bagian dari golongan yang membahsa mengenai kalamullah. Golongan ini memiliki sebuah pendapat bahwa Allah tidak berbicara tetapi Allah menciptakan perkataan dalam dirinya sendiri dan menjadikan selin dari-Nya sebagai penjelas. Dalam pandangan golongan Jahmiyah kalamullah merupakan suatu hal yang berupa kiasan tidak arti yang sesungguhnya atau tidak merupakan perkataan Allah yang sesungguhnya karena Allah yang menciptakan perkataan itu dan disebutlah sebagai yang maha berkata sehingga Dia-lah yang menciptakan perkataan dari sisi-Nya.

\section{Kalamullah menurut golongan Kullubiyah}

Golongan Kullubiyah merupakan golongan dalam islam yang dicetuskan oleh Abdullah bin sa'id bin Kullab, dari sinilah pengikutpengikutnya disebut dengan Kullubiyah. Golongan ini memiliki seuah pendapat mengenai kalamullah yaitu Al-Qur'an itu adalah hikayat atau implementasi dari kalamullah, pendapat ini muncul karena menurut mereka kalamullah merupakan makna yang ada pada Dzat Allah dan selalu bersama dengan-Nya. Golongan ini berpendapat bahwa yang merupakan makhluk adalah susunan dari huruf dan dibunyikan dengan suara, bukan kalamullah dalam artin sesungguhnya yang menjadi makhluk karena kalamullah adalah qadim dan yang qadim merupakan hal yang kekal dan ada di dalam 
dzat Allah sendiri, sedangkan susunan dari huruf dan suara adalah hal baru yang tidak kekal sehingga disebut dengan makhluk.

\section{Kafirnya orang yang berpendapat bahwa Al-Qur'an adalah makhluk}

Dalam pembahasan yang telah terurai diatas ada golongan islam yang memiliki pendapat bahwa Al-Quran merupakan makhluk Allah yang diciptakan setelah-Nya dan tidak qadim bersama dengan dzat Allah. Sehingga ulama' berpendapat bahwa orang yang berkata bahwa Al-Qur'an adalah makhluk menjadi kafir.

Menurut Imam Malik berkata bahwa siapa yang mengatakan AlQur'an itu makhluk, maka ia dipukul, hingga dipenjara sampai mati. Imam Malik berpendapat demikian di dalam kitabnya. Menurut Imam Syafi'i berpendapat bahwa Al-Qur'an itu kalamullah dan bukan makhluk. Menurut Imam Ahmad bin Hambal berkata bahwa siapa yang mengatakan bahwa Al-Qur'an itu makhluk, maka menurut kami iakafir karena Al-Qur'an itu termasuk ilmu Allah dan di dalamnya terdaoat nama-nama Allah. Menurut Sufyan Ats-Tsaury berpendapat bahwa jika ada orang yang mengatakan firman Allah dalam suarat annaml ayat 9 adalah makhluk maka orang tersebut telah menjadi kafir zindiq dan halal darahnya.

Dari beberapa pendapat ulama' diatas telah dapat diambil sebuah kesimpulan yang menyatakan bahwa orang-orang yang menganggap kalamullah yang berupa Al-Qur'an adalah makhluk dan tidak qadim maka orang-orang tersebut telah menjadi kafir. Karena jka Al-Qur'an menjadi makhluk maka menyamakan ucapan Allah atau lama Allah dengan ucapan manuia padahal Allah tidak serpa dengan makhluk ciptaannya.

D. Kesimpulan 
Kalamullah merupakan ucapan Tuhan yang disampaikan kepada makhluknya sebagai pedoman hidup maupun berisi perintah ibadah. Dalam pembahasan kalamullah sejak dahulu sudah menjadi perdebatan dalam kehidupan ber islam. Persoalan kalmullah ini muncul sejak dimulainya masa Khulafaurrasyidin atau sejak Rasulullah wafat, persoalan kalamullah yang merupakan bagian kecil dari teologi sebenarnya bermula Karena pembahasan politik kemudian meluas menjadi persoalan teologi.

Pembahasan yang dilakukan oleh beberapa golongan islam memunculkan beberapa pemikiran mengenai kalamullah, dari pemikiran-pemikiran yang muncul tersebut menjadikan bahan pembahasan hingga saat ini karena dalam pembahasan itu muncul orang yang dianggap kafir karena suatu pemehamannya terhadap persoalan kalamullah ini. Pemikiran pertama mengenai kalamullah disampaikan oleh golongan Mu'tazilah yang berkesimpulan bahwa kalamullah (Al-Qur'an) merupakan makhluk dan bukan merupakan bagian dari Tuhan yang Qadim ata kekal. Sementara itu menurut golongan Asy-ariyah dan Maturidiyah kalamullah (Al-Qur'an) tidaklah makhluk melainkan bagian dari dzat Tuhan sendiri yang ada sejak zaman azali dan sifatnya qadim, dan yang menjadi makhluk adalah susunan huruf dan suara yang menyusun Al-Qur'an itu sendiri.

Menurut golongan jahmiyah kalamullah merupakan suatu hal yang berupa kiasan tidak arti yang sesungguhnya atau tidak merupakan perkataaan Allah yang sesungguhnya karena Allah yang menciptakan perkataan itu dan disebutlah sebagai yang maha berkata sehingga Dia-lah yang menciptakan perkataan dari sisi-Nya. Menurut golongan Kullubiyah Al-Qur'an itu adalah hikayat atau implementasi dari kalamullah, pendapat ini muncul karena menurut mereka kalamullah merupakan makna yang ada pada Dzat Allah dan selalu bersama dengan-Nya, dan yang merupakan makhluk adalah 
susunan dari huruf dan suara. Karena kalamullah yang sesungguuhnya sifatnya Qadim.

Menurut beberapa ulama' pendapat yang mengatakan bahwa Al-Qur'an adalah makhluk adalah kesalahan dan menjadi kafir. Hal itu didasari karena Al-Qur'an bersifat qadim yang ada sejak azali, jika dianggap susunan huruf dan suara adalah kalamullah maka sama saja dengan menyamakan Tuhan dengan makhluk, sedangkan Tuhan memiliki sifat yang berbeda dengan makhluk.

Kalamullah adalah firman Allah yang harus kita yakini kebenaran dan kenyataan-nya, apalagi kita sebagai umat islam harus beriman terutama terhadap apa yang kita tidak lihat (imanen). Begitu banyak (thoriqot) atau jalan dalam memahami ilmu-ilmu Allah, sehingga muncul banyak golongan yang menjalankan dengan berbagai macam cara dan aturan, hal itu biasa terjadi dalam kalangan manusia dalam menjalankan dan memahami syariat, dikarenakan Allah sendiri mengatakan (litaarofu) untuk saling mengenal, jadi kita sesama manusia hanya bisa melaksanakan bukan saling menilai, dan Allah lah yang mempunyai hak prerogatif dalam menilai manusia itu benar atau salah.

Dengan demikian puncak dari segala ilmu adalah tauhid yaitu penyatuan kita untuk kembali kepada allah. Golongan dan aliran itu hanyalah jalan yang ditempuh manusia, tetapi pencapian hidup manusia semua itu sama, yaitu selamat kembali kepada Allah.

\section{Evaluasi}

1. Baca teks ini dengan seksama, kemudian lakukan paraphrase (encoding) di setiap sub babnya!

2. Buat sebuah komentar menggunakan Thesis annotation, The probe annotation, Personal view annotation, dan Inventive 
annotation terhadap teks di atas untuk mengomentari setiap sub-babnya!

3. Buat kelompok diskusi setiap kelompok terdiri dari 5 orang mendiskusikan masalah-masalah berikut dan tuliskan hasil diskusinya:

a. Bagaimana sifat Kalam menurut para Madhab

b. Argumentasi bahwa Allah pasti punya sifat kalam

c. Apakah Al-Qur'an itu kalamullah atau makhluk

\section{Referensi}

Abdu I-Muhsin, 'Abdu r-Razzaq bin. Al-Qaul Al-Sadid Fi Ar-Raddi 'Ala Man Ankara Taqsima t-Tauhid. Edited by Dar Ibnu L-Qayyim. 1st ed. Riyad, 2003.

Al-Maqrizi, Taqiyuddin Ahmad bin Ali. Tajridu T-Tauhid Al-Mufid. Kairo: Markaz I-Kitab li n-Nashr, n.d.

Al-Maturidi, Abu Manshur Muhammad bin Muhammad. Kitab AtTauhid. Beirut: Dar Shadir, 2001.

Al-Qahtani, Sa'id bin 'Ali bin Wahf. Nur T-Tauhid Wa Dhulmatu s-Shirk Fi Dau'i I-Kitab Wa s-Sunnah. 3rd ed. Riyad: Maktabah Malik Fahd, 2000.

Al-Wali, Husain. Kitab Kalimatu T-Tauhid. 1st ed. Mesir: Maktabah AlWa'idz, 1908.

Jabbar, Abdul. Al-Mughni Fi Abwabi t-Tauhid Wa I-'Adl. Mesir: Wizarah Al-Thaqafah Al-Mishriyyah, n.d.

Yasri, Muhammad. 'Ilmu t-Tauhid 'Inda Ahl s-Sunnah Wa I-Jama'Ah. 1st ed. سلسلة المدخل المفيد إلى علم التوحيد 1, Islamkotob.com.

Al-Ghazali, Abu Hamid. Ihya' Ulumuddin. 1st ed. Beirut: Dar Ibnu Hazm, 2005. 
- - - Tahafut Al-Falasifah. Edited by Sulayman Dunya. 6th ed. Kairo: Daru I-Ma'arif, 1980.

Ibnu Sina, Abu 'Ali Al-Husain. Al-Risalah Al-'Arshiyyah Fi Tawhidihi Ta'Ala Wa Sifatuhu. 1st ed. Omman: Matabi' Dairah alMa'arif al-'Amaniyyah, 1934.

- - . An-Najah Fii I-Mantiq Wa I-Ilahiyyat. Edited by Majid Fakhry. Beirut: Daru I-Afaq Al-Jadidah, 1982. 


\section{Daftar Pustaka}

Al-Ghazali, A. H. (2005). Ihya' Ulumuddin (1st ed.). Dar Ibnu Hazm.

- - Tahafut Al-Falasifah. Edited by Sulayman Dunya. 6th ed. Kairo: Daru l-Ma'arif, 1980.

Abdu I-Muhsin, 'Abdu r-Razzaq bin. Al-Qaul Al-Sadid Fi Ar-Raddi 'Ala

Man Ankara Taqsima t-Tauhid. Edited by Dar Ibnu L-Qayyim. 1st ed. Riyad, 2003.

Al-Farabi, Abu Nashr. Araa'u Ahli I-Madinah Al-Fadilah Wa Madhadatuha. Edited by Ali bu Mulham. 1st ed. Beirut: Dar wa Maktabah Al-Hilal, 1995.

- - - Kitabu S-Siyasah Al-Madinah. Edited by Ali bu Mulham. Beirut: Dar wa Maktabah Al-Hilal, n.d.

Al-Maqrizi, Taqiyuddin Ahmad bin Ali. Tajridu T-Tauhid Al-Mufid. Kairo: Markaz I-Kitab li n-Nashr, n.d.

Al-Maturidi, Abu Manshur Muhammad bin Muhammad. Kitab AtTauhid. Beirut: Dar Shadir, 2001.

Al-Qahtani, Sa'id bin 'Ali bin Wahf. Nur T-Tauhid Wa Dhulmatu s-Shirk

Fi Dau'i I-Kitab Wa s-Sunnah. 3rd ed. Riyad: Maktabah Malik Fahd, 2000.

Al-Wali, Husain. Kitab Kalimatu T-Tauhid. 1st ed. Mesir: Maktabah AlWa'idz, 1908.

Anthony V. Manzo. (1985). Expansion Modules for the ReQuest, CAT, GRP, and REAP Reading/Study Procedures. Journal of Reading, 28(6), 498-502.

http://www.jstor.org/stable/40029529

Bertrand Russel, History of Western Philosophy and Its Connection With Political and Social Circumstances From the Earliest Times to The Present Days, 2nd ed. (New York: George Allen and Unwin LTD, 1949).

Broad, C. D. "Arguments for the Existence of God," Journal of Theological Studies 40 (1939): 16-30; 156-67. Retrieved September 20, 2007.

Bucaille, Maurice. The Bible, The Qur'an and Science. Edited by Alastair D. Pannel and Maurice Bucaille. Lahore: Kazi Publications, n.d. 
Boyer, Pascal. Religion Explained: The Evolutionary Origins of Religious Thought. New York: Basic Books, 2001.

Brown, Delwin, Sheila Greeve Davaney, and Kathryn Tanner (eds.). Converging on Culture: Theologians in Dialogue with Cultural Analysis and Criticism. (Reflection and Theory in the Study of Religion) American Academy of Religion Book, 2001. ISBN 978-0195144673.

Cell, Edward. Language, Existence, and God. New York: Abingdon Press, 1971. ISBN 0687210631

Cohen, Morris R. "The Dark Side of Religion," Religion Today, a Challenging Enigma, ed. Arthur L. Swift, Jr. (1933). Revised version in Morris Cohen, The Faith of a Liberal (1946). Retrieved September 20, 2007.

Cahyaningtyas, A. P., \& Mustadi, A. (2018). The Effect of REAP Strategy on Reading Comprehension. SHS Web of Conferences 42, 00014, 1-6. https://doi.org/https://doi.org/10.1051/shsconf/201842000 14

Eliade, Mircea. "Monotheism." In Encyclopedia of Religion. New York:

MacMillan Publishing, 1987. ISBN 978-0029094808

Frazer, James George. The Golden Bough: A Study in Magic and Religion. New abridgment from 2nd and 3rd eds. Oxford University Press, 1998. ISBN 0192835416 (originally published in 1900)

Ganggi, R. I. P. (2017). Pendidikan Pemakai di Perpustakaan Sebagai Upaya Pembentukan Pemustaka yang Literasi Informasi. Khizanah Al-Hikmah : Jurnal Ilmu Perpustakaan, Informasi, Dan Kearsipan, 5(1), 121-128. https://doi.org/http://dx.doi.org/10.24252/kah.v5i1a11

Ginanjar, M. H., \& Kurniawati, N. (2017). Pembelajaran Akidah Akhlak Dan Korelasinya Dengan Peningkatan Akhlak Al-Karimah Peserta Didik (Studi Kasus Di Madrasah Aliyah Shoutul Mimbar Al-Islami Tenjolaya Bogor). Jurnal Edukasi Islami Jurnal Pendidikan Islam, 6(12), 101-124.

Greer, John Michael. A World Full of Gods: An Inquiry Into Polytheism. ADF Publishing, 2005. ISBN 0976568101 
Hume, David. Dialogues Concerning Natural Religion. New York: Routledge, 1991.

Huxley, Thomas. Collected Essays Volumes 1-7. New York: D. Appleton \& Co, 1896-1910.

Huxley, Thomas. Man's Place in Nature and other Anthropological Essays, London: Macmillan, 1906.

Haisch, Bernard. The God Theory: Universes, Zero-Point Fields and What's Behind It All. San Francisco: Red Wheel/Weiser Books, 2006.

Hume, David. 1779. Dialogues Concerning Natural Religion. Edited by Richard Popkin. Indianapolis: Hackett, 1998.

Hutton, Ronald. The Triumph of the Moon: A History of Modern

Pagan Witchcraft. Oxford: Oxford University Press, 2001. ISBN 0192854496

Ibnu Sina, Abu 'Ali Al-Husain. Al-Risalah Al-'Arshiyyah Fi Tawhidihi Ta'Ala Wa Sifatuhu. 1st ed. Omman: Matabi' Dairah alMa'arif al-'Amaniyyah, 1934.

- - - An-Najah Fii I-Mantiq Wa I-Ilahiyyat. Edited by Majid Fakhry. Beirut: Daru I-Afaq Al-Jadidah, 1982.

Jabbar, A. (1996). Sharh Ushuli I-Khamsah (3rd ed.). Maktabah Wahbah.

Jackson J. Spielvogel, Western Civilization, 7th ed. (Canada: Thomson Wadsworth, n.d.);

Kannengeiser, C. "Atheism." Encyclopedia of Religion. Edited by Mercia Eliade. New York: MacMillan Publishing, 1987.

Khan, Wahidu d-Din. Al-Islam Yatahadda. Edited by Zafarul Islam Khan. 4th ed. New Delhi: Goodword Books, 2005.

Kirsch, Jonathan. God Against the Gods: The History of the War Between Monotheism and Polytheism. Penguin, 2005. ISBN 0142196339

Kirsch, Jonathan. God Against the Gods: The History of the War Between Monotheism and Polytheism. Penguin, 2005. ISBN 0142196339

lew, Antony. God and Philosophy. Amherst, NY: Prometheus Books, 2005. 
Lindow, John. Handbook of Norse mythology. Santa Barbara, CA: ABC-CLIO, 2001.

Manzo, A., Manzo, U., \& Albee, J. J. (2002). iREAP: Improving Reading, Writing, and Thinking in the Wired Classroom. Journal of Adolescent \& Adult Literacy, 46(1), 42-47. http://www.jstor.org/stable/40017504

Manzo, U., \& Manzo, A. V. (2010). The Informal Reading-Thinking Inventory (IR-TI) The Informal Reading-Thinking Inventory: Assessment Formats for Discovering Typical \& Otherwise Unrecognized Reading \& Writing Needs - and Strengths. http://anthony-manzo.blogspot.com/2010/06/informalreading-thinking-inventory-ir.html

MacDonald, Nathan. "The Origin of 'Monotheism'." In Early Jewish and Christian Monotheism, edited by Loren T. Stuckenbruck and Wendy E. S. North. London: T \& T Clark International, 2004. ISBN 0567082938

Mackie, J. L. The Miracle of Theism. Oxford: Oxford University Press, 1982.

Nielson, Kai. Ethics Without God. London: Pemberton Books, 1973. Nurhayati. (2014). Akhlak dan Hubungannya dengan Aqidah dalam Islam. Mudarrisuna, 4(2), 289-309.

Ochshorn, Judith. The Female Experience and the Nature of the Divine. Bloomington: Indiana University Press, 1981. ISBN 025331898XPaley, William, 1802. Natural Theology. Indianapolis: Bobbs-Merrill, 1963.

Pagels, Elaine. Adam, Eve, and the Serpent. New York: Random House, 1988. ISBN 0679722327

Pattah, S. H. (2014). Literasi Informasi Peningkatan Kompetensi Informasi dalam Proses Pembelajaran. Jurnal IImu Perpustakaan \& Kearsipan Khizanah Al-Hikmah, 2(2), 117128.

Prager, Dennis. "Ethical Monotheism."Jewishvirtuallibrary. Retrieved April 29, 2006.Ray, Matthew Alun. Subjectivity and Irreligion: Atheism and Agnosticism in Kant, Schopenhauer, and Nietzsche. Burlington, VT: Ashgate, 2003. 
Renette, R. (2016). Using REAP (Read, Encode, Annotate, Ponder) In Teaching Reading. Proceedings of the Fourth International Seminar on English Language and Teaching (ISELT-4), 278282.

Rohi, Rajinder Kaur. Semitic and Sikh Monotheism: A Comparative Study. Patiala, India: Punjabi University Publication Bureau, 1999. ISBN 8173805504

Rusyd, Ibnu. Al-Kasyf Fi Manahiji I-Adillah Fi Aqa'idi I-Millah,. Edited by Muhammad Abid Al-Jabiri. 1st ed. Beirut: Markaz Daru IWihdah Al-Arabiyyah, 1998.

Setyowati, L. (2015). Literasi Informasi Dilihat dari Perspektif Modal

Manusia. Libraria: Jurnal Perpustakaan, 3(2), 232-246. https://doi.org/10.21043/libraria.v312.1594

Silberman, Neil A. et al. The Bible Unearthed. New York: Simon and Schuster, Reprint edition, 2002.

Smith, Mark S. The Early History of God: Yahweh and Other Deities in Ancient Israel, Second ed. Grand Rapids, MI: William B. Eerdman's, 2002.

Spencer, Herbert. First Principles. London: Routledge/Thoemmes, 1996.

Spielvogel, J. J. (n.d.). Western Civilization (7th ed.). Thomson Wadsworth.

Stein, Gordon. "Agnosticism." In The Encyclopedia of Unbelief (Volume 1). Buffalo, NY: Prometheus Books, 1985. 3-4.

Sukma, \& Haryadi. (2016). Keefektifan Strategi REAP Dan Request Dalam Pembelajaran Membaca Pemahaman Siswa Kelas VIII Smp. LingTera, 3(1), 99-111. https://doi.org/http://dx.doi.org/10.21831/It.v3i1.8476

Tylor, Edward B. Primitive Culture: Researches into the Development of Mythology, Philosophy, Religion, Language, Art and Custom. 2 vols. (original 1871) reprint ed. Kessinger Publishing, LLC, 2007. Vol. 1: ISBN 0548128219; and vol. 2: ISBN 0548128227

Yasri, Muhammad. 'Ilmu t-Tauhid 'Inda Ahl s-Sunnah Wa I-Jama'Ah. 1st ed. سلسلة المدخل المفيد إلى علم التوحيد 1, Islamkotob.com. 
Zasrianita, F. (2016). Using Of Reading, Encoding, Annotating, And Pondering (REAP) Technique To Improve Students' Reading Comprehension (A Classroom Action Research at Eighth Grade Students in MTSN 1 Kota Bengkulu in Academic years 2016). Ta'dib, 19(2), 147-164. 


\section{BIODATA PENULIS}

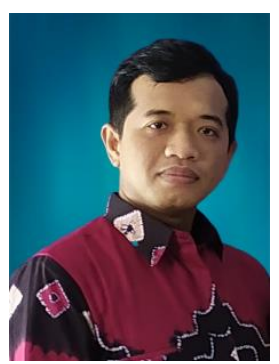

Dzulfikar Akbar Romadlon, M.Ud lahir di Sidoarjo, 19 Maret 1991. Gelar sarjana diperoleh dari Institut Studi Islam Darussalam (ISID) Gontor pada tahun 2012 dengan konsentrasi Aqidah dan Pemikiran/Filsafat Islam. Penulis melanjutkan studi S2 di Institut Studi Islam Darussalam Gontor konstentrasi Ilmu Aqidah, lulus pada tahun 2014. Pengalaman penulis adalah praktisi di dunia pendidikan tingkat menengah atas. Selanjutnya, tahun 2015 penulis memulai karirnya sebagai dosen di Fakultas Agama Islam Universitas Muhammadiyah Sidoarjo.

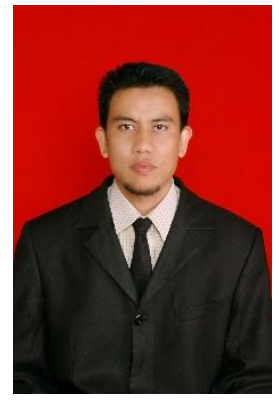

Doni Septi, Lc., M.Pd. lahir di Kuranji, 11 September 1978, Gelar sarjana di bidang Syari'ah diperoleh dari LIPIA Jakarta tahun 2007, Magister Pendidikan Islam dari Universitas Islam Negeri Maulana Malik Ibrahim tahun 2011. Penulis pernah menjadi dosen di STIBA Arraayah Sukabumi, hingga tahun 2016. Kini penulis adalah dosen di Fakultas Agama Islam Universitas Muhammadiyah Sidoarjo. 